\title{
El Sacramento de la Penitencia como fuente de la misericordia
}

\author{
Vicente Pastor de los Cobos \\ Enrique Gómez García ${ }^{1}$
}

Fecha de recepción: septiembre 2020.

Fecha de aprobación: septiembre 2020.

\section{Sumario:}

Tras el Concilio de Trento prolifera la literatura contrarreformista que aborda la manera de confesarse. La juridización de este sacramento y las controversias establecidas entre protestantes y católicos, jansenistas y ortodoxos, contricionistas y atricionistas, exigían cierta claridad para administrar válidamente un sacramento en cierta medida magificado y expuesto a la escrupulosidad. Al final de sus días, Pastor de los Cobos escribió una muestra de ello, en la que, amén de traslucir los tópicos teológicos del momento, presenta la Penitencia como un acontecimiento de misericordia divina, subraya su procesualidad e incluso barrunta lo que se puede denominar causalidad intencional del sacramento.

\section{Palabras clave:}

Sacramento de la penitencia; Concilio de Trento; Protestantismo; Rigorismo moral; Atricionismo; Contricionismo; Juicio de misericordia.

\section{The Sacrament of Penance as a source of mercy}

\section{Abstract:}

After the Council of Trent counter-reformist literature that addresses the way to confess proliferates. The juridization of this sacrament and the controversies established between Protestants and Catholics, Jansenists and Orthodox, contricionists and atricionists, demanded some clarity in order to validly administer a sacrament to some extent turned into magic act and exposed to scruples of conscience. At the end of his days, Pastor de los Cobos wrote a sample of this, in which, in addition to transcending the theological topics of the moment, he presents Penance as an event of divine mercy, underlines its processuality and even glimpses what can be called the intentional causality of the sacrament.

\section{Keywords:}

Sacrament of Penance; Council of Trent; Protestantism; Moral rigorism; Atricionism; Contricionism; Judgment of Mercy

\footnotetext{
${ }^{1}$ Introducción, edición y transcripción de la documentación. Doctor en Teología Dogmática (Universidad Pontifica de Salamanca). Profesor de la Universidad Loyola Andalucía - Facultad de Teología e invitado del Centro Teológico San Agustín (UPSa). https://orcid.org/0000-0001-56616136<egomez@uloyola.es>
} 


\section{Notas biográficas sobre el autor}

Entre el Barroco y la racionalidad que anticipa la Ilustración transcurre la vida de don Vicente Pastor de los Cobos, personalidad reconocida de la Granada dieciochesca. Tanto es así que su persona y obra merecieron el respeto y la adhesión de un grupo de discípulos - 'aficionados al autor' y 'apasionados de sus doctrinas' $-^{2}$ que difundió su obra por considerarla de inestimable valía en unos tiempos, los de la Guerra de la Independencia, en los que reinaba la impiedad $^{3}$. A uno de ellos, el canónigo del Sacromonte don Juan Rodríguez Aragón, se le debe una voluminosa biografía de nuestro protagonista, que sirvió de fuente para redactar la síntesis que precede la edición póstuma de su Disertación crítico-mística, de la que extraemos y cotejamos algunos datos biográficos ${ }^{4}$.

Conforme a dicho resumen, Vicente nació en Granada el 22 de enero de 1688, dato que la historiografía contemporánea corrige en dos años, datando dicho nacimiento en $1686^{5}$. Fueron sus padres Juan Pastor y María de los Cobos, miembros de distinguidas familias valencianas afincadas en la ciudad Nazarí y devotos del afamado santo levantino san Vicente Ferrer, en honor del cual recibe nombre nuestro autor.

La vinculación de Vicente con la abadía del Sacromonte le viene de pequeño, pues tuvo como padrino de bautismo al señor Mendoza, canónigo de la misma. Tanto aquellos como este le procuraron una esmerada formación, como muestra que cursara sus estudios superiores en el Colegio de San Dionisio del Sacromonte, institución académica de prestigio en la ciudad. Erigido para una treintena de becados e inaugurado en octubre de 1610, muy pronto recibió ciertos privilegios, como el de admitir a grados mayores a sus canónigos (1613) o el de poder presentarse estos a examen sin estar matriculados en los cursos de la Universidad (1617). Además, gozó del Patronato Real (1621),

${ }^{2}$ Cf. AA. VV., Disertación crítico-mística. Respuesta que dio el Venerable Señor D. Vicente Pastor de los Cobos a una consulta teológica que se le hizo acerca del estado espiritual de una religiosa, Imprenta Nueva de don Francisco Benito Valenzuela, Granada 1815, I y IV respectivamente.

3 "Uno de los medios más aptos (para sacar al pueblo del estado de envilecimiento en el que ha caído) es dar a conocer al público el mérito virtuoso y literario de los hombres grandes, que han sostenido la fe y la piedad con sus doctrinas y exemplos. Y siendo tan singular en lo uno y en lo otro el del eminente varón don Vicente Pastor de los Cobos, Canónigo que fue del Sacro-Monte extramuros de Granada" (AA. VV., Disertación... III-IV).

${ }^{4}$ Cf. AA. VV., Disertación... XI-XXVIII.

${ }^{5}$ Cf. M. Barrios Aguilera, "Vicente Pastor de los Cobos": http://dbe.rah.es/biografias/85789/ vicente-pastor-de-los-cobos. Todas las referencias informáticas fueron consultadas por última vez el 26 de mayo de 2020. 
año en el que el papa Gregorio XV le concede la venia de otorgar grados de bachiller, licenciado, doctor y maestro en filosofía y teología. Posteriormente, en 1752, aún en vida de Pastor de los Cobos, se erigieron en él las cátedras de Leyes hasta el grado de Bachiller (prerrogativa vigente hasta 1845), de Historia Eclesiástica y de Lenguas Orientales, hecho que propició que se acogieran estudiantes seglares en sus aulas ${ }^{6}$.

Durante sus años como colegial, Vicente destacó por su amabilidad, su devoción y su aptitud hacia el estudio, lo que le valió el sobrenombre de 'otro san Luis Gonzaga'. También era conocido por su carácter autosuficiente, que lo inclinaba hacia ciertas actitudes soberbias, manifiestas en sus escritos apologéticos y polemistas. Se desenvolvió como lector empedernido, lo que le granjeó un significativo acervo cultural. Conforme a los suyos, sentía predilección por las obras de san Juan de la Cruz y santa Teresa de Jesús, pero, como veremos, no se escaparon de sus manos ni los Santos Padres, de entre los que destaca Agustín de Hipona, ni los grandes teólogos medievales, entre los que sobresalen Tomás de Aquino y Bernardo de Claraval, ni autores modernos, que le sirven unas veces para ratificar sus ideas, otras, para rebatir las contrarias.

Ya presbítero, fallecido el padre Torres en 1713, fue elegido canónico de la abadía, y en ella fungió como catedrático, confesor y director espiritual. En cuanto a lo primero, adquirió la Cátedra de Vísperas de Teología, así como leyó cinco cursos de filosofía y sustituyó a algunos profesores en otras cátedras. Por lo segundo y tercero, influyó en los colegiales del San Dionisio y, sobre todo, confrontó sus lecturas con la experiencia.

Desde los treinta y tres hasta los cincuenta y nueve años, alternó momentos de crisis y de calidez espiritual. Así, Luis Francisco de Viana, coetáneo suyo, colegial de San Dionisio como él, canónigo y catedrático, además de abad y administrador de la abadía y organizador de su biblioteca, deja constancia de su ascetismo y de "las grandes inspiraciones, los raptos y vuelos de espíritu, las comunicaciones internas y las ilustraciones y afectos íntimos" de los que gozó durante estos años ${ }^{7}$.

${ }^{6}$ Cf. M $M^{\mathrm{a}}$. L. García Valverde, "El Colegio de San Dionisio Areopagita de Granada": http:// www2.ual.es/ideimand/el-colegio-de-san-dionisio-areopagita-de-granada/; F. Martín Zúñiga y M. Vico Monteoliva, "El Colegio de Teólogos y Juristas San Dionisio Areopagita del Sacro-Monte de Granada (1752-1800)": Historia de la Educación. Revista interuniversitaria 3 (1984) 89-108; Ma. C. Calero Palacios y F. Crespo Muñoz, "El Colegio de San Dionisio Areopagita del Sacromonte de Granada. El fondo documental”: M. C. Calero Palacios, J. M. de la Obra Sierra y M. J. Osorio Pérez (coords.), Homenaje a María Angustias Moreno Olmedo (Granada, Universidad de Granada, 2006), 393-410.

${ }^{7}$ Citado en M. Barrios Aguilera, "Vicente Pastor de los Cobos". Sobre Luis Francisco de Viana, 
En el ámbito pastoral, participó en varias misiones populares sacromontanas, promovidas por el obispo Pedro de Castro, en consonancia con la labor desempeñada por la Compañía de Jesús. Según sus seguidores, Pastor de los Cobos predicaría hasta diez. Habida cuenta de que su objetivo consistía en reavivar la vida de fe de los sencillos, y fomentar la conversión y la reforma de sus costumbres, la confesión pasaba a ser una celebración indispensable en estos eventos, máxime tras el magisterio de san Vicente de Paúl y san Juan Eudes ${ }^{8}$. De ahí que no suene a conjetura afirmar que, en ellas, nuestro autor regala a sus interlocutores con su predicación y con sus aptitudes para la confesión.

Orientó sus dotes intelectuales a la investigación histórica de corte apologético, destacando en este ámbito la defensa de lo que Barrios Aguilera denomina "invenciones y fundaciones sacromontanas", promovidas por Pedro de Castro y centradas en los mártires granadinos y en la veracidad de los famosos libros plúmbeos ${ }^{9}$. Dichas defensas surgieron a raíz de la condena de estos libros por el Papado en 1682. A Diego de la Serna, jurista vallisoletano y fiscal de la Real Chancillería de Granada por la época, se le deben las Vindicias Catholicas Granatenses (1706), en las que define las líneas argumentales prolaminares: la extrañeza de que Roma condene los libros y no las reliquias, la verdad y antigüedad de los contenidos desarrollados en aquellos y las declaraciones favorables a la Inmaculada Concepción contenidas en ellos.

Como quiera que esta obra resultara inservible, por su voluminosidad y acritud, para cumplir su función de alegato que moviera al Pontífice a revisar el juicio, Pastor de los Cobos, discípulo de De la Serna y quizá alentado por Viana y por el cabildo de la abadía, retomó este quehacer apologético y escribió Guerras Cathólicas Granatenses (1730) e Historia apologética sobre las ya postradas Láminas Granadinas (1738). Por estas obras, aunque no se imprimieron y no llegaron a fungir como suplicatorio, fue admitido como académico correspondiente en la Real Academia de la Historia el 28 de mayo de 1742. En las memorias de dicha institución figura como catedrático de la Universidad de Granada y canónigo de la colegiata del Sacromonte ${ }^{10}$. Además, ese mismo año se le concedió la licencia para leer libros prohibidos.

cf. Íd., "Luis Francisco de Viana y Bustos": http://dbe.rah.es/biografias/85798/luis-francisco-de-viana-y-bustos. Sobre su implicación en la controversia de los libros plúmbeos, cf. Íd., "Del "Modo único decoroso' de vindicar las 'invenciones' sacromontanas: la Dissertación de Urbina y Dusfusa”: Sharq al-Andalus 20 (2011-2013) 595-601.

${ }^{8}$ Cf. G. Flores, Penitencia y unción de enfermos (Madrid, BAC, 1993), 216-217.

${ }^{9}$ Cf. M. Barrios Aguilera, La invención de los libros plúmbeos. Fraude, historia y mito (Granada, Editorial Universidad, 2011), 239-418.

${ }^{10}$ Cf. Memorias de la Real Academia de la Historia, I (Madrid, Imprenta de Sancha, 1796), CLIII. 
Falleció en olor de santidad el 20 de agosto de 1759, a los setenta y un años de edad y tras una dolorosa enfermedad.

\section{Prolífico Escritor y apologeta incansable}

Los adeptos de Pastor de los Cobos expresan que de su pluma salieron muchos manuscritos, que han de considerarse un "tesoro de sabiduría sacerdotal" ". Más aún, al finalizar su reseña biográfica, traen a colación algunos títulos, que estructuran de la siguiente manera ${ }^{12}$ :

- Obras de índole mística, entre las que citan Pecadora arrepentida; Beata de Torre Ximeno y, sobre todo, la Disertación crítico-mística. Respuesta que dio el $V^{r}$. $S^{r}$. D. Vicente Pastor de los Cobos a la consulta teológica que se le hizo acerca del estado espiritual de una religiosa, que es la que editan. A su parecer, se trata de su obra cumbre, en la que

vació el señor Pastor el caudal de su sabiduría, sin darse cuidado de observar un método exacto en el orden de las ideas, ni menos evitar las repeticiones, que a su fecunda imaginación servían de explanación más ilustrada del asunto ${ }^{13}$.

Más allá de lo acertado o no de dicha valoración, estas páginas no resultarían más significativas que el manuscrito, actualmente perdido, que Barrios Aguilera titula Libro grande de mística, en el que el autor desarrollaría todo su saber sobre esta materia. Este manuscrito, asimismo, tuvo cierta repercusión en su vida, dado que le acarreó problemas con el Santo Oficio al ser denunciado por un escritor escolástico poco versado en estas cuestiones y recibir una apreciación negativa por parte de los correspondientes censores inquisitoriales. Este hecho le obligó a redactar tres defensas, en las que desmenuza las lecturas erróneas que hicieron de su obra ${ }^{14}$.

- Obras de calado canónico moral. En este apartado citan un Tratado de la mentira moral y un Tratado de las reglas para directores de almas, así como un compendio de Derecho Civil y otro de Derecho Canónico.

\footnotetext{
${ }^{11}$ AA. VV., Disertación... IV.

${ }^{12}$ Cf. AA. VV., Disertación... XXVI-XXVII.

${ }^{13}$ AA. VV., Disertación... V.

${ }^{14}$ Cf. M. Barrios Aguilera, "El Sacromonte de Granada o el mito incesante": El fingidor 13/14
} (2001) 12. 
- Obras de historia eclesiástica. Aquí incluyen cuatro tomos de Historia universal, una Historia del Sacromonte y los ya citados cuatro tomos sobre la ficción plúmbea. A decir de Barrios Aguilera, fue esta la obra que gozó de mayor fortuna.

- Obras de literatura eclesiástica, donde refieren un tomo sobre la Predestinación y una Impugnación al Padre Mansi sobre el amor de Dios.

El simple repaso de estos títulos pone de manifiesto el carácter enciclopédido y la erudición de nuestro personaje, que sus adeptos resumen con los siguientes calificativos: "Astuto filósofo, profundo teólogo, agudo escriturario, canonista excelente, historiador discreto, sabio de su siglo" ${ }^{15}$. Ni que decir tiene que esta crítica ha de ser hoy matizada.

Así, por ejemplo, es de suponer que estos afines emplean el calificativo 'discreto' que acompaña a 'historiador' en el sentido de 'moderado, sin exceso', tal como recoge la Real Academia de la Lengua ${ }^{16}$. Esta valoración se situraría en la línea de lo que el autor quiere que se le reconozca en su memorial sobre la cuestión del Sacromonte y, lejos de adquirir el sentido peyorativo que usualmente se le atribuye al término, denotaría la objetividad exigida a todo historiador.

Sin embargo, tal como muestra Barrios Aguilera, Vicente compartió con sus compañeros de cabildo la vehemencia ideológica con la que, a la vera de Viana y de De la Serna, se defendían los escritos sacramontanos. Por ello afirma de su obra que

tiene la virtud de marcar la temperatura ideológica existente en el Sacromonte y ejemplificar la vehemente determinación de que no se rompa la cadena vindicativa, reforzando internamente, esto es, dentro del propio ente colegial, la convicción en la verdad de la causa ${ }^{17}$.

Lo mismo se podría decir del resto de sus escritos, como el que aquí se trascribe, en el que la supuesta moderación y equilibrio en sus planteamientos dejan paso a una mordaz ironía, que tiende a humillar la doctrina que ataca y a caricaturizar a aquel con quien entra en controversia. En parte, sus discípulos son conscientes de esto cuando describen su estilo con estas afirmaciones, en buena parte acertadas:

\footnotetext{
${ }^{15}$ AA. VV., Disertación... XXVI.

${ }^{16} \mathrm{Cf}$. https://dle.rae.es/discreto

${ }^{17}$ M. Barrios Aguilera, "Sobre los moriscos del reino de Granada y el fin del país islámico. Preguntas y propuestas de estudio": IX Simposio Internacional de Mudejarismo. Actas. (Teruel, Centro de Estudios Mudéjares, 2004), 421.
} 
Su ciencia es sublime, y su estilo nervioso, sin el aliño de la humana elocuencia, que es impropia del evangelio y de su espíritu que la obra contiene; pero es lleno, serio, siempre agradable, a veces arrogante, otras punzante y elocuente ${ }^{18}$.

\section{Nuestra obra y nuestra transcripción}

El manuscrito que se publica por primera vez en estas páginas lleva por título Respuesta a un religioso docto y timorato que consultó sus miedos y escrúpulos de su conciencia en la administración del Santo Sacramento de la Penitencia a gentes sin temor de Dios ni enmienda de sus culpas. Tal como versa en su último folio, data del 15 de mayo de 1756, es decir, apenas tres años antes de su muerte. Se trata, por consiguiente, de uno de sus últimos escritos, donde se puede advertir la madurez de su pensamiento. Además, en dicho folio $70 \mathrm{v}$, se refleja que esta respuesta se trasladó, supuestamente al interesado, el año de 1761, una vez fallecido el autor.

Si se atiende a la anterior clasificación de sus obras, se incluye entre sus reflexiones canónico-morales. En efecto, tanto esta respuesta como la previa Respuesta a un cura sobre el modo de portarse en el confesionario con los que vienen forzados del precepto al cumplimiento de la Iglesia, escrita casi veinte años antes (1737), son claros ejemplos de la nutrida literatura contrarreformista que abordaba los modos de confesarse ${ }^{19}$, con la consiguiente confluencia de teología, consejos espirituales y normas canónicas, debido a la necesaria recta ejecución del sacramento para no incurrir ni en su invalidez ni en su ilicitud, motivo de fondo que parece conjuntar estos folios ${ }^{20}$.

El extenso título de esta Respuesta resulta explícito a la hora de concretar su temática. Un clérigo, que a lo largo de la obra recibe diversas denominaciones -algunas de las cuales denotan su ironía despectiva (Señor Mío, Vuestra Merced, Vuestra Paternidad, Padre Maestro)-, se torna escrupuloso y estima un peso insoportable administrar el sacramento de la penitencia a aquellos de

${ }^{18}$ AA. VV., Disertación... VII.

${ }^{19}$ En la obra que nos atañe, esto queda manifiesto en su crítica a la 'sola fe' protestante y al coram Deo de los novatores (cf. Regla II, 9v), en su defensa, exhaustivo uso y comentario de las consignas tridentinas (que en ocasiones deriva en repeticiones innecesarias y que llega a poner por encima de la enseñanza de los Santos Padres), en su rebatimiento expreso a teólogos protestantes (cf. Regla III, 16v-17r)...

${ }^{20}$ Cf. A. González Polvillo, Análisis y repertorios de los tratados y manuales para la confesión en el mundo hispánico (ss. XV-XVIII) (Huelva, Universidad de Huelva, 2009), 71. 
quienes se percata que no se enmiendan y siguen pecando, incluso ostensiblemente; vienen, en definitiva, sin preparación para el sacramento (cf. Regla I, 6r-6v). Este hecho le lleva a cuestionarse la conveniencia o no de absolver a quienes no muestren 'evidencia' de su arrepentimiento, lo que indica, a juicio del autor, cierta 'soberbia farisaica' del confesor en el ejercicio de su ministerio. Más aún, Pastor de los Cobos le plantea a su interlocutor que, tras el rigorismo de sus planteamientos, se esconde el desconocimiento de lo que es un sacramento, de su institución, de su fin e, incluso, de su virtud, ya que duda de su eficacia (cf. 2r).

Del contexto se desprende que dicho religioso tantea al autor con una serie de preguntas y que le solicita ciertas reglas que lo ayuden a discernir cuándo administrar o cuándo dilatar, e incluso negar, la absolución a los penitentes. Este, por su parte, amparado en la diversidad de personas, circunstancias y tiempos que rodea al sacramento (cf. Regla VI, 34r), reconoce la dificultad de responder a tal petición. Su escrito en absoluto es un recetario -reglas fijas y concretas para cada uno de los 'casos' (cf. Regla VI, 31v)- que solucione todos los problemas, dado que estos consejos "son de práctica de confesionario" (1r) y no se pueden normatizar, a riesgo de incurrir en abstracciones contraproducentes. De ahí que tan solo exponga ciertas generalidades (cf. Regla VI, $32 \mathrm{v}$ ), correspondiéndole al confesor ser templado "en sus ardores", ser fuerte "para animarse a trabajo tan molesto y espinoso", ser justo "para la igualdad en lo que se deba al sacramento, y más al próximo", y, sobre todo, ser prudente, para cumplir su misión con acierto (cf. Regla VI, 32r).

Aun así, Pastor de los Cobos redacta setenta folios, paradójicamente divididos en once reglas, que, bien vistas, se presentan a manera de consejos que orienten en el arte del discernimiento por parte del confesor. Aunque en sus reflexiones proliferan las comparaciones y los ejemplos (unas veces tomados de la vida diaria, otros, de la Escritura) que le sirven para concretar sus razonamientos, resultar didáctico y recrearse literariamente, no incurre en el casuismo, al que parece proclive su interlocutor. Además, en su argumentación se advierten ciertos postulados renovadores de la teología de la época.

Desentrañando el contenido del escrito, en los folios introductorios aduce un primer consejo como marco general: resulta necesario no alterar el orden del sacramento, es decir, situar los medios por encima del fin al que se orientan, algo en lo que insiste más adelante cuando apela a las doctrinas agustinianas del uti y el frui y del ordo amoris (cf. Regla VII, 38v). En consonancia con el Tridentino, el fin del sacramento de la penitencia apunta a la salvación del prójimo, mientras los medios atañen a la manera como se administra, recayendo aquí lo que escrupuliza al confesor (cf. 1r; 3r). Dicho esto, el autor da paso a sus reglas. 
La primera responde a la duda sobre la validez del sacramento si los penitentes no vienen preparados 'al gusto del confesor', lo que hace que este abunde en la explicación y en la exhortación con el propósito de prepararlos y convertirlos en el sacramento, para así 'oler el dolor', es decir, la conversión del fiel. De no ser de este modo, ha de negarse la absolución (cf. Regla I, 4r). A esto responde Vicente Pastor que la cuestión no radica en que los penitentes vengan sin dolor, sino en si el confesor es fiel al fin del sacramento: la salvación. Es esto lo que debe buscar el confesor, y no la conversión. Extenderse en la doctrina solo consigue aburrir, cansar e irritar a la gente, ahuyentándola de la práctica sacramental, y, al negar la absolución, se acarrean más males que bienes (cf. Regla IX, 48r) ${ }^{21}$. Además, la desconfianza sobre la preparación del que solicita el sacramento esconde sobre todo la miseria y el desconocimiento que el confesor tiene de sí y de sus pecados, por lo que conviene que este se preocupe más estos que de los de los demás, ya que solo así curará las llagas ajenas (cf. Regla VI, 32v; VII, 36r). Le aconseja que ame a los penitentes, pues a través del amor se los edifica (cf. Regla I, 7r).

En la segunda regla exhorta a su interlocutor a creer en la bondad y eficacia del sacramento. Para fundamentar lo dicho, relaciona la práctica de la penitencia con la del bautismo. Si es cierto que se administra aquella a pecadores que parecen despreciar la gracia que se les da, no lo es menos que en la Iglesia primitiva se confería el bautismo a personas adultas carentes de preparación y que, una vez bautizadas, seguían viviendo como si no fueran cristianas. Sin embargo, a pesar de esto, en aquella época el bautismo "se daba sin aflicción ni amargura", con un talante festivo y alegre (cf. Regla II, 8r-8v), uso que se perpetúa en el s. XVIII. Se debe, por tanto, suministrar la penitencia con la misma alegría con que se bautiza (cf. Regla II, 13v-14r).

Esta reflexión le sirve al autor para desarrollar ciertos aspectos relevantes de la teología penitencial, de los que me fijo en tres. Destaca, en primer lugar, la comprensión orgánica del dinamismo sacramental, expresado en la interrelación existente entre bautismo y penitencia. Esta es "muy parecida al del agua en la virtud inmensa de dar gracias y perdonar culpas, de justificar al hombre pecador, volviéndole a la estola primera de la gracia y dándole al Espíritu Santo por el que se ahijó, y por eso (es) heredero del reino" (Regla II, 13v). Aun con todo, la primacía recae en aquel, tal como expresa cuando asume la teología patrística de la penitencia como 'segundo bautismo' y como

\footnotetext{
${ }^{21}$ Como compendia en otra norma, es mejor administrar un sacramento, sabiendo que nada malo resulta de ello, que negarlo, conscientes de que de su omisión se espera gran mal. Este principio rige, por ejemplo, cuando se absuelve a un enfermo, independientemente de que se vea, o no, que está bien preparado para recibir el sacramento (cf. Regla IX, 50v).
} 
'segunda tabla de salvación' (cf. Regla II, 8r; 13v) 22, de modo que resitúa el sacramento de la reconciliación, lo centra como se reivindica actualmente ${ }^{23}$. Además, salvaguarda la especificidad de cada cual: mientras el primero es "jubileo plenísimo, o indulgencia plenaria que Dios concedió al mundo... por justicia ajena, sin satisfacción propia" (Regla II, 11r-v); la segunda atañe a los males propios y voluntarios, y requiere del compromiso para alcanzar la salvación, "porque, perdida tanta gracia por voluntad propia, ya es preciso que el pecador bautizado haga frutos dignos de penitencia" (Regla II, 14r). En la eficacia sacramental, por tanto, sin minusvalorar la gratuidad salvífica procedente de Dios, confluyen esta y la colaboración humana, tal como subraya el concilio con la formulación del non ponentibus obicem (cf. DH 1606) y con su reflexión sobre la necesidad de los actos del penitente (cf. DH 1704), en especial de la satisfacción (cf. DH 1712-1713). Por último, acuña la opinión clásica de que este sacramento atiende al reato del pecado: "Dando el bautismo tanta gracia, aún no quita la concupiscencia e ignorancia", algo que sí hará la penitencia (Regla II, 13v) $)^{24}$.

En segundo lugar, comenta el texto de $\mathrm{Hb}$ 10,26-27, de interpretación problemática en aquella época y que servía a los rigoristas para no administrar el sacramento a quienes consideraban indignos. Huyendo de un larvado laxismo, algo que se percibe a lo largo de su escrito, el Pastor de los Cobos reconoce que la práctica eclesial ha negado ambos sacramentos a quienes, con terquedad, se obstinan en pecar; pero, huyendo del rigorismo, apela a la práctica agustiniana de bautizar al que lo pidiere, aunque su vida fuera escandalosa y sin presunta enmienda (cf. Regla II, 9r). Comparte, así, el principio patrístico de que un confesor es fiel al sacramento si lo concede a quien "lo quiere y lo pide con la segura creencia (de) que es la segunda tabla" de salvación (Regla II, 13r), ya que "la Iglesia a nadie cierra esa puerta, y al que lo pide con buena voluntad, se le franquea la entrada" (Regla III, 14v-15r). Resitúa, así, la cuestión: no se trata tanto de la evidencia de 'oler el dolor', que exigía el confesor, cuanto de la capacidad de indagar la voluntad de quienes se acercan a él (cf. Regla II, 10v).

${ }^{22}$ Sirva como ejemplo de la primera, Didascalia apostolorum, 2; y, de la segunda, Tertuliano, De paenitentia 4, PL 1, 1233; san Jerónimo, Epistula ad Demetriadem, 130, PL 22, 1115. La tradición también se refiere a la pentiencia como bautismo de lágrimas, por diferenciarlo del de agua (cf. Ambrosio de Milán, Epistula XLI, 12, PL 16, 1116; Gregorio Nazianceno, Oratio XXXIX in sancta lumina, 17, PG 36, 356); y como bautismo oneroso o laborioso por lo que implica (cf. Juan Damasceno, De fide ortodoxia IV,9, PG 94, 1124). Cf. Trento, XIV sesión, Doctrina sobre el sacramento de la penitencia, cap. 2, DH 1672.

${ }^{23}$ Cf. F. Millán, La penitencia hoy. Claves para una renovación (Madrid, UPCo-DDB, 2001), 220-228.

${ }^{24}$ Cf. P. Fernández, El sacramento de la penitencia (Salamanca, San Esteban, 2003), 120-124. 
Con esta crítica al rigorismo arremete contra movimientos eclesiales como los novacianos, los montanistas, los tertulianistas, los donatistas, los luciferanos... $\mathrm{y}$, desde luego, los jansenistas, tendencia significativa de la época. La inflexibilidad no es del gusto del Señor, apuntilla, que recriminó a los Zebedeos que pidieran que bajara fuego del cielo para exterminar a quienes no los acogían y, máxime, que dio su vida por los pecadores (cf. Regla II, 11v-13r).

En tercer lugar, si el sacramento tiene como fin la salvación, la práctica penitencial impuesta por Trento expresa que beneficia más al penitente la asiduidad en su recepción que el confesarse de tarde en tarde y, sobre todo, su negación. "Ahora, aduce, la Iglesia está más gobernada, y con más continencia, por el precepto de confesar y por la frecuencia con que se recibe" (Regla II, 10r). De estas palabras se deprenden dos realidades: por una parte, su valoración positiva de la denominada penitencia devocional -de la que dirá en otros lugares que posibilita que los fieles sean 'más continentes, más refrenados y con una conciencia más cuidada' (Regla IX, 48r), y desde la que explicará, en virtud de 'la multitud y frecuencia', que se dé el caso de que se acerquen al sacramento penitentes no del todo preparados e incluso malvados (cf. Regla V, 28v)-; por otra, su comprensión evolutiva de la práctica sacramental, estimando la marcada por el Tridentino más perfecta que la ejercida en la épocas anteriores (cf. Regla IX, 48r). Esta comprensión genética de los sacramentos resulta indispensable para no absolutizar ciertas modalidades históricas y abrir posibilidades de futuro ${ }^{25}$, aunque, en el caso que nos compete, disentamos de la visión y argumentos esgrimidos por el autor.

Es precisamente con esta idea con la que comienza la tercera regla, en la que ensalza la doctrina tridentina con la glosa de los cánones 3, 4, 6 y 7 de la famosa Sesión XIV. Según Vicente Pastor, en la Contrarreforma se celebra mejor el sacramento que en la antiguiedad, postulado contrario al protestante, porque la Iglesia se ha desarrollado más y comprende mejor las enseñanzas del Maestro (cf. Regla III, 14r-14v). Antes se tenía poca idea de este sacramento (cf. Regla IV, 20v). De ahí que no deba extrañar que infravalore la práctica eclesial antigua (cf. Regla III, 16v-16r), que primaba "la penitencia interna" y pública, imponía una gravosísima satisfacción y promovía la irrepetibilidad del sacramento. En parte justifica esta actuación por tratarse de un estado eclesial aún imperfecto, en el que la Iglesia obraba con sumo cuidado debido a la 'infantilidad' de los cristianos, que, ante las exigencias de la integridad del sacramento, tal como defiende el concilio, podían retornar a la gentilidad (cf. Regla IV, 27r).

\footnotetext{
${ }^{25}$ Interesante, en este sentido, la perspectiva genética expresada por J. Granados, Tratado general de los sacramentos (Madrid, BAC, 2017).
} 
Por lo que se refiere a su necesidad para la salvación, subraya la insuficiencia de la contrición si esta no lleva al sacramento. En cuanto a su frecuencia, alude al mandato de confesar los pecados una vez al año y confesarse antes de comulgar (cf. Regla V, 28v). Preserva su integridad, mentando las diversas partes del sacramento (contrición, confesión, absolución y satisfacción) y reconociendo que el ejercicio del tiempo recoloca esta última, ya que la práctica antigua seguía la lógica contrición, confesión, satisfacción y absolución (cf. Regla III, 16r).

Por lo que atañe a su institución por Cristo y a la facultad de la Iglesia para continuarlo, comenta la 'potestad de las llaves' a la luz de Jn 20,23, que es el texto citado por el Tridentino (cf. Regla III, 16r-16v). En este ítem se incluye su vuelta a la exégesis de $\mathrm{Hb} 10,26-27$, y concluye que el hagiógrafo se refiere aquí al pecado de apostasía (equiparable al pecado contra el Espíritu Santo) -que se da cuando, conscientemente, se rompe el cuerpo de la Iglesia(cf. Regla III, 15v), por lo que la negación de la penitencia no se ha de aplicar a todos los pecados, como si el apóstol estuviera en contra del sacramento. Apunta, además, la diversidad eclesial a la hora de abordar dicho pecado, señalando que algunos piensan que la potestad de las llaves no tiene poder sobre estos pecados gravísimos, dando a entender que el autor se distancia de esta opinión.

Defiende, asimismo, la institución del sacramento por derecho divino, en oposición a los reformadores, que sostienen que la confesión privada no se daba en la antigüedad, por lo que resulta novedosa, y propugnan la confesión coram Deo (cf. Regla III, 16v-17r). Es de reseñar en su tratamiento de este asunto su apertura, pues plantea cómo entender el 'derecho divino'. Es consciente, por una parte, de que los católicos no pueden demostrar que desde antiguo se practicara la confesión privada y, por otra, reconoce la diversidad de interpretaciones expresadas en la discusión conciliar $^{26}$. Como sugiere la teología actual, se debe aclarar si en los lugares donde el concilio emplea esta fórmula significa siempre lo mismo, y si el derecho divino recae sobre el sacramento de la reconciliación en sí o sobre la forma concreta de practicar una parte del sacramento, que es la confesión privada auricular ${ }^{27}$.

${ }^{26}$ Extraña que el autor obvie en su argumentación a que, sin negar lo dicho, los conciliares reconocen que la confesión privada no es la única práctica de este sacramento. Así, se admite la confesión pública (cf. DH 1683), la penitencia pública (cf. DH 1708), la penitencia antigua (DH 1692) y los casos reservados (cf. DH 1686). De hecho, el autor dedica unas líneas a estos últimos (cf. Regla II, 13r; III, 18r-18v), amparado en el concilio, mientras atiende a la costumbre de la penitencia pública en el s. XVIII solo para casos extremos, remitiendo únicamente a la práctica eclesial (cf. Regla II, 13r).

${ }^{27}$ Sobre la cuestión del derecho divino, cf. J. Equiza, "El sacramento de la penitencia y el Concilio de Trento": Íd. (dir.), Para celebrar el sacramento de la penitencia (Estella, Verbo Divino, 2000), 
El tratamiento de algunos de estos temas prosigue en la cuarta regla, en la que el autor se revela como un teólogo positivo, conocedor de las escuelas existentes en la época. El sacramento se debe administrar conforme a la intención de Cristo en el modo y la disposición definidos por Trento, que puso orden a la diversidad de ideas y de prácticas ocasionadas por el tiempo y las circunstancias:

El Espíritu ha dado plena idea a la Iglesia para su frecuencia, para su útil práctica... El modo, la solemnidad, la frecuencia, la menor penitencia, la idea mayor que hay de esa potestad para dar y enriquecer a los fieles arrepentidos, y para ayudar aun a los difuntos, es lo nuevo y mejor ordenado, como sucede en la práctica del sacramento con más fruto y provecho de todos (Regla IV, 20r).

Ataja así la tesis protestante de que el concilio haya cambiado la sustancia del sacramento al ordenar su integridad, cuando en la Iglesia antigua, y más concretamente san Juan Crisóstomo, se defendía la penitencia interna, o coram Deo (cf. Regla IV, 22v). El autor analiza el sentido y la razón de ser de la primacía de la contrición en la práctica patrística, y busca la continuidad entre esta y la de su época, a fin de mostrar que la integridad es de derecho divino.

Ahora bien, este pronunciamiento conciliar no obvia el apunte realista de que se trata de una integridad 'condicionada'28. Así, "hoy en muchos casos

108-117. Entre los autores que defienden la analogía del sentido de la expresión, además de J. Equiza, se hallan A. Amato, I pronunciamenti Tridentini sulla necessita della confessione sacramentale nei canoni 6-9 della sessione XIV, Bibliotheca theologica salesiana, Roma 1974, 106-120, 165-179, y D. Borobio, El sacramento de la reconciliación penitencial, Sígueme, Salamanca 2011, 145-146. Entre quienes sostienen la univocidad, cf. F. Arocena Solano, Penitencia y unción de los enfermos, Eunsa, Pamplona 2018, 125; P. Fernández, El sacramento de la penitencia... 252, 253-254, si bien este autor matiza que el derecho divino recae en la institución de la confesión, no en su forma concreta (si pública o privada).

${ }^{28}$ El c. 7 de la sesión XIV del Tridentino dictamina la confesión íntegra "de todos y de cada uno de los pecados mortales... aun los ocultos... y las circunstancias que cambian la especie del pecado"; pero puntualiza: "Confesar todos los pecados mortales que se recuerdan tras conveniente y serio examen" (DH 1707). Intérpretes del concilio sostienen que con este matiz se sugiere que tal integridad está condicionada por la capacidad física y moral de los penitentes (teólogos conventuales, Catarino, Cano, Trapper), interpretación que se fundamenta en el comentario del capítulo 5 del Tratado sobre el sacramento de la penitencia de dicha sesión (cf. DH 1680; 1682). La lógica de Pastor de los Cobos la traduce a la perfección D. Borobio cuando exclama: "Tal exigencia (de la integridad) no es absoluta, matemática y material, hasta el punto que condiciona el valor del sacramento, obsesiona al ministro o atormenta al sujeto" (D. Borobio, El sacramento de la reconciliación penitencial... 147).

No es este el único tema en el que el autor interpreta la doctrina conciliar. Reglas más adelante, ante la petición por parte del interlocutor de una norma que garantice saber cuándo la absolución le es útil al penitente y cómo percibir los actos requeridos por el Tridentino para darla caritativamente (contrición, confesión y satisfacción), el autor distingue entre lo dicho por el concilio y lo que se 
se da el sacramento sin esa integridad de la confesión, porque esa dispensa la piden las circunstancias" (Regla VI, 35v). En el reverso de este folio, aunque versa sobre la adaptación del confesor a la diversidad de los penitentes por lo que a la doctrina se refiere, enumera ciertos casos a los que se les puede aplicar la condicionalidad conciliar: semifatuos, alocados, simples, balbucientes... Como apunte anecdótico, de tinte casuista, echa mano en diversos lugares a ciertas listas de pecados, siendo quizá la más extensa la recogida cuando habla sobre la integridad (cf. Regla IV, 22v-23r).

La quinta regla reubica la problemática: si el sacramento de la penitencia no resulta útil a quien lo recibe no depende de la mala administración por parte del ministro, sino de la mala voluntad con la que se acercan los fieles. El confesor se tiene que preocupar de sí mismo, no de los otros; es decir, de si es fiel a su misión. Conforme a este criterio, y según la práctica eclesial, es preciso conceder la absolución a quien no lo merece, sin que esto se le cuente en el haber del ministro, si este obra con caridad sincera.

Para ratificar lo dicho, repasa la práctica con la que se administran otros sacramentos. Así, la comunión también se expone al acercamiento de personas que no la merecen (además, se pone la hostia en la lengua, siendo esta la que más peca; se acercan a comulgar sin confesión previa o mal confesados), y ello no suscita escrúpulos a quien la reparte. Los obispos, ni más ni menos, como ministros ordinarios, confirman sin confesión previa: "Basta con que estén contritos, y no confesados" (Regla V, 30r). Lo mismo puede decirse de las órdenes, especialmente las menores, del matrimonio y de la unción de los enfermos: se dan sin que se verifique que el que se acerca está bien confesado.

A esta argumentación pareciera que el interlocutor objeta que no se puede aplicar este criterio a la penitencia, ya que el resto de los sacramentos se da por gracia y misericordia, mientras este se otorga a modo de juicio (cf. Regla $\mathrm{V}, 30 \mathrm{v}$ ); y es ahí donde surge el problema, porque, siendo juez, el ministro desconoce cuándo dar o privar de la absolución (cf. Regla VII, 37r). Sobre la cuestión de la judicatura, que afecta al centro del sacramento en la propuesta conciliar por oposición a la sola índole declaratoria protestante (cf. DH 1709), giran la séptima y novena reglas, si bien disemina su respuesta por otros lugares. Sistematizamos así su pensamiento.

Nunca debe olvidar el confesor que tan solo es el 'administrador' (cf. Regla IX, 51r) de la gracia de Dios, para que se derrame en quien se acerca al sacramento. Aquella, por tanto, no le pertenece y, por consiguiente, no le corresponde a él discriminar su distribución, planteamiento que recuerda las

arroga el confesor: aquel expresa que tres son las partes integrantes del sacramento, pero no que el ministro deba percatarse de las tres para absolver al pecador (cf. Regla VIII, 40v). 
palabras del papa Francisco en EG 47: "A menudo nos comportamos como controladores de la gracia y no como facilitadores. Pero la Iglesia no es una aduana, es la casa paterna donde hay lugar para cada uno con su vida a cuestas". A las claras lo expresa Pastor de los Cobos en la sexta regla, cuando, al recapitular lo que le compete al confesor -"dar al penitente la doctrina a su ignorancia ${ }^{29}$, la medicina a sus llagas y la absolución al que la necesita y desea" (Regla VI, 32v)-, enfatiza que las dos primeras son caudal propio de quien confiesa, mientras la tercera "no es de caudal propio, ni depende de su virtud ni esfuerzo", sino que es "caudal del amo" (Regla I, 4r), "patrimonio de Jesucristo" (Regla IX, 51r), gracia del crucificado (cf. 3r; Regla II, 11r; 14r; VI, 33r; IX, 46v-46r, 48v; 52r) ${ }^{30}$. En definitiva, el sacramento es don de Cristo (cf. Regla VII, 38r).

En otro lugar lo refiere con la bella alegoría de la fuente, metáfora de la Trinidad $^{31}$, que derrama su gracia a través de un caño, imagen del ministro, y llena toda jarra, penitente, independientemente de las condiciones en las que esta se encuentre (cf. Regla V, 27v). En otro, exhorta a su interlocutor a asu-

${ }^{29}$ Por lo que atañe a la doctrina, una vez más el autor muestra su pericia. Se opone a quienes la absolutizan haciendo de ella, como se dijo en otra ocasión, el recurso para provocar la conversión del penitente. El sacramento no se debe confundir con la predicación, ya que esta no es parte integral, sino dispositiva, del mismo (cf. Regla 6, 34r-34v). La doctrina se ordena a corregir e instruir (cf. Regla $6,35 \mathrm{v}$ ), por lo que tiene que ser poca y prudente (cf. Regla $6,35 \mathrm{r}$ ) -de modo plástico lo expresa líneas antes: "No se fie vuestra paternidad tanto de sus doctrinas y esfuerzos a diestro y siniestro, que más valen cuatro palabras a tiempo, y oportunas, que mil importunas al tiempo, a las personas y a las llagas" (Regla VI, 34r)-: lo primero, para que no resulte inoportuno para el resto de los fieles que esperan para confersarse, ya que lo hacen en demasía; lo segundo, porque debe atender a la diversidad de personas que se confiesan. Podría verse aquí una invitación a no confundir el sacramento con la dirección espiritual.

${ }^{30}$ Entre las referencias a la cruz y al crucificado como fuente de gracia y perdón, cito la siguiente, por sintetizar su pensamiento: “¿Qué sabemos si la cruz, por gracia y por exceso de su liberal grandeza, le quiso dar (porque quiere, y nadie le puede limitar sus dones) la remisión de la pena eterna, hasta que sea digno de la gracia y se acerque por contrición a ella?" (Regla IX, 53r-53v).

${ }^{31}$ Es de advertir que, para este bello apunte trinitario, el autor se apropia de la formulación del papel de las divinas personas en la creación, que pone de manifiesto el canon primero del segundo Concilio de Constantinopla (553) (cf. DH 421), basado en el dato bíblico de Rom 11,36 y 1Cor 8,6. Esta confesión trinitaria adquiere un sentido especial en Agustín de Hipona, quien lo emplea con un acento antiarriano, siguiendo a Mario Victorino y a Ambrosio de Milán (cf. mor. I,14,24, PL 32, 1321-1322; c. s. Ar. 31,29, PL 42, 704; N. CipRIANI, "Fuentes cristianas de la doctrina trinitaria en los primeros Diálogos de san Agustín": Augustinus 56 (2011) 343).

No es este el único lugar en el que Pastor de los Cobos se refiere a la densidad trinitaria del sacramento. Así, subraya el papel de las divinas personas en la fórmula de absolución (cf. Regla IX, 54r) y explica trinitariamente las múltiples de causas del pecado: "El que peca por flaqueza se dice que peca contra el Padre; el que peca por ignorancia se dice que peca contra el Hijo y el que peca de malicia se dice que peca contra el Espíritu Santo" (Regla XI, 63r). 
mir lo que es: mediador del único Salvador -dispensador, dice también (cf. Regla I, 42)-, y no corredentor con él, de modo que no cargue sobre sí los pecados de los demás, sino sobre los hombros de Cristo (cf. Regla VII, 36r-36v), si bien esto es lo que desconoce: tocar la carga sin cargarla sobre sus hombros. Más aún, lo acusa de presuntuoso y achaca sus escrúpulos a su soberbia, dado que la presunción le impide creer en el sacramento y lo lleva a cercenar los canales de la misericordia divina. La providencia de Dios resulta inescrutable e invisible (cf. Regla VII, 39r).

Además, en la confesión se tratan cuestiones de conciencia, y el ministro sabe que solo Dios escruta los corazones de cada uno (cf. Regla VIII, 43r-43v), siendo el único que los conoce a cabalidad y que puede juzgar lo que en ellos ocurre (cf. Regla V, 28r) -conocimiento que le resulta imposible al confesor, que no deja de ser humano y que solo puede acceder al interior del penitente en tanto en cuanto este lo informe (cf. Regla IX, 45v)-. El ministro es juez, sí, mas juez de comisión, juez terreno del tribunal de la misericordia en favor del reo, por lo que su indagación será una pesquisa inicial (cf. Regla IX, 46v). En cuanto tal debe examinar dos realidades: a) que se pide la confesión de verdad y con recta intención (el querer); b) que el sacramento le servirá de provecho y no de daño. O lo que es lo mismo, debe conocer la causa que se confiesa para que discrimine lo que conviene al penitente por caridad y mirando a su cura: si absolver, condenar o negar la absolución (cf. Regla IX, 45r; X, 58r-58v), dada la condición diversa de cada cual. Se debe recurrir en la pastoral a métodos variados, ya que a algunos les puede venir bien el rigor, mientras a otros resultarles contraproducente ${ }^{32}$.

Tiene que considerar, igualmente, que la conversión del pecador, que es lo que exige clarificar su interlocutor para juzgar que cumple y dar así la absolución, la inicia Dios (cf. Regla VIII, 42v; IX, 46r), por lo que la contrición -“la

\footnotetext{
${ }^{32}$ Con este énfasis en la dimensión judicial del sacramento y del ministro, Pastor de los Cobos es coherente con las enseñanzas conciliares, pero evita extralimitar dicha estructura judicial de manera que se igualara a la civil -de hecho, el concilio emplea un significativo "sed ad instar actus judicialis, quo ab ipso, velut a judice" (DH 1685)-, aspecto en el que redundará, como veremos más adelante, al completar esta dimensión jurídica con la medicinal. De esta manera, opta por una tendencia abierta y centrada, separándose también de aquellas corrientes 'novatoras' que incurrían en el laxismo moral y penitencial. Así, estima condenadas con justicia es; as corrientes que "quitaban al confesor juez la obligación de penetrar en cada uno lo que conviene para absolverlo", y defendían la mera transmisión verbal de una voluntad futura de enmienda como prueba suficiente para absolver. Más adelante carga contra la práctica de una "anchura tirana", que nada tiene que ver con la "blandura caritativa" (cf. Regla XI, 70r). Por otra parte, al inicio de su escrito fundamenta la dimensión dialógica del sacramento en dicha perspectiva judicial: la penitencia es cosa de dos, porque es preciso que uno relate su causa y otro la oiga para dictar sentencia (cf. 2v). Buen comentario a la estructura judicial del sacramento, sus posibles extralimitaciones y la necesidad de su centramiento, cf. D. BoroBIo, El sacramento de la reconciliación... 151-153.
} 
mudanza que trae el penitente"- difícilmente resulta perceptible a los sentidos (cf. Regla VIII, 43r-43v). Más aún, es lógica divina salvar a los hombres por medios ordinarios, y no milagrosos, por lo que no busca conversiones espectaculares (cf. Regla VIII, 42v; IX, 47r). El criterio, por tanto, para absolver no viene dado por el sentido y juicio falible del ministro (cf. Regla VIII, 44r). De ahí que este deba actuar como Jesús, que juzga secretamente y no expulsa ostentóreamente a los que obran el mal (cf. Regla V, 29v); y que, en la cruz, perdona, aunque no todos fueran dignos de su perdón (cf. Regla X, 57v). Si se obra de este modo, se evitarán las funestas arbitrariedades pastorales en las que se incurre, puesto que "los dictámenes de los hombres son diferentes, y sobre una misma seña hay mil dudas" (Regla VIII, 43r).

Si Dios es la fuente de la gracia y el verdadero juez, la penitencia ha de verse, según se ha dicho, como un juicio de misericordia (cf. Regla II, 13v; V, 28v). Así, la dimensión jurídica del sacramento se compensa con su vertiente medicinal (cf. 2v; Regla VI, 33r-33v): el confesor ayuda, da la mano, corrige, sana. La penitencia, antes que nada, es una obra de caridad, que procura el bien del prójimo (cf. DH 1685), consistiendo en ello el fin de este sacramento (cf. Regla VII, 38r), esto es: "desear que se salve, alegrándose de sus bienes, que conducen a su salvación, y sintiendo los males que le estorban conseguirla", a lo que se une orar por él y hacer el bien aun a los malvados (cf. Regla IX, 45v-45r). De ahí que, si el confesor ama cuando administra el sacramento, haga lo que haga (incluso el negar la absolución), obrará fiel y caritativamente (cf. Regla VII, 37r). Esta es la razón que lleva al autor a renegar del rigorismo y de la estrechez morales por las que se guía su interlocutor, pues "toda ley, regla, prohibición y ordenanza mira a la caridad, la que no es estrecha, sino (que) dilata" (Regla VI, 31v) ${ }^{33}$.

Por consiguiente, el confesor ha de recordar lo siguiente: que, por ser la Iglesia una casta meretriz y estar mezclados en ella los justos y los pecadores, "fue providencia altísima que el bien sacramental de unos fuese expuesto a todos" (Regla V, 31r; VII, 37r); que el ministro debe distinguir lo que le toca

${ }^{33}$ En este contexto se entiende el atinado apunte eclesial, según el cual la Iglesia aparece como mediadora de esa gracia, fungiendo como "pública escuela de enseñanza y hospital de medicina" (Regla V, 28r), simel tan parecido al "hospital de campaña" al que nos tiene acostumbrados el papa Francisco (cf. Discurso a los participantes en la Asamblea General del movimiento de los focolares (26/9/2014): http://www.vatican.va/content/francesco/es/speeches/2014/september/documents/papa-francesco_20140926_movimento-focolari.html; Audiencia general (28/8/2019): http://www.vatican.va/content/francesco/es/audiences/2019/documents/papa-francesco_20190828_udienza-generale.html; Mensaje con ocasión del día internacional de la enfermeria (12/5/2020): http://www.vatican. va/content/francesco/es/messages/pont-messages/2020/documents/papa-francesco_20200512_messaggio-giornata-infermiere.html). La Iglesia pretende con sus acciones la salvación del que confiesa, pues Cristo le legó este "tesoro" de la penitencia para redención de los perdidos (cf. Regla VI, 31v). 
y lo que puede hacer (cf. Regla IX, 49r) de lo que le corresponde al penitente, sin asumir como propias las culpas que dependen de libertades ajenas (cf. Regla VIII, 40r); que a él le compete buscar la "utilidad del prójimo", no su propia satisfacción, de suerte que el darlo o el negarlo mira únicamente a este fin (cf. Regla V, 31r; VII, 38v); que tiene que administrarlo prudente y justamente (cf. Regla V, 29v), dejándose guiar por la honestidad, que todo lo ordena, y no por la concupiscencia, que todo lo desordena (cf. Regla VII, 39v); que lo único que debe requerir del penitente para la absolución es que desee (crea) en el sacramento y lo pida con buena voluntad (cf. Regla V, 28v), tal como procede la Iglesia con los enfermos y moribundos (cf. Regla VIII, 40v-41r, 42v); y es un hecho que, en quienes se confiesan, se ven "señas probables, al menos", de arrepentimiento, habida cuenta de que el acercarse a la confesión implica ya humildad (cf. Regla V, 30v): el penitente se rinde, obedece, propone y comunica así su buena voluntad (cf. Regla VII, 37r); y estas señales que muestran que el penitente cree en la virtud del sacramento y lo pide con voluntad verdadera y ánimo sincero han de considerarse ya inicio de contrición (cf. Regla IX, 46r, 50v), siendo esto lo que puede advertir el confesor.

$\mathrm{El}$ autor se sugmerge en las disputas de la época entre atricionistas y contricionistas, en las que no entra Trento. Estos, representados por los profesores de Lovaina y La Sorbona (Morin, Berti, Gazzaniga, Billuart), más rigoristas, sostienen que el atrito tenía que llegar a ser contrito en el sacramento. Aquellos, más aperturistas, se identifican con los franciscanos, jesuitas y salmanticenses, y estiman que es suficiente con una atrición que excluya la voluntad de pecar con la esperanza de alcanzar el perdón divino ${ }^{34}$.

El interlocutor se encuadra entre los contricionistas, debido a la lectura estricta de la norma tridentina: dado que la contrición es el acto más preciso del sacramento, se requiere de la contrición perfecta, y no solo de su inicio, para la absolución. Nuestro autor, por el contrario, se inserta entre los atricionistas, la corriente más seguida en la época tras la sentencia de Alejandro VII en 1667 (cf. DH 2070), la admisión por parte de Inocencio XI del probabilismo y del probabiliorismo (cf. DH 2175-2177) y las condenas de Alejandro VIII (1690) y Clemente XI (1713) del jansenismo -y más concretamente, en este último caso, de Pascasio Quesnel (cf. DH 2307; 2314-2321; 2444, 2460-2462, 2467) ${ }^{35}$-. Se-

${ }^{34}$ Buena síntesis de la cuestión en J. Ramos Regidor, El sacramento de la penitencia, Sígueme, Salamanca 1976, 286-293.

${ }^{35}$ Sobre los sistemas ético-morales del momento y la aportación de san Alfonso María de Ligorio, cf. J. Vico Peinado, Éticas de ayer y de hoy (Madrid, San Pablo, 1991), 54-69; D. Capone, "Sistemas morales": F. Compagnoni, G. Piana, S. Privitera y M. Vidal (dirs.), Nuevo diccionario de teología moral (Madrid, Paulinas, 1990), 1708-1718; M. Vidal, "Del rigorismo a la benignidad. Significado histórico de la moral alfonsiana": Moralia 10 (1988) 157-191. 
gún Pastor de los Cobos, basta para administrar el sacramento con atrición o contrición imperfecta (con su inicio), que ya es conversión verdadadera a Dios, aunque resulte imposible cuantificar la mudanza (cf. Regla IX, 48v-99r; 52v).

La continua valoración por parte del autor del inicio de la conversión y la reiteración de su desenvolvimiento, de modo que el sacramento tienda a perfeccionarla y plenificarla, subraya otro aspecto de la penitencia, inusual durante estos siglos. Una manera de centrar esta, como recoge la teología actual, es la de insertar el sacramento en el proceso integral de conversión: es la contrición primera la que mueve al penitente a acercarse al sacramento, y este lo fortalece para que siga consumando cotidianamente su retorno a Dios ${ }^{36}$.

Dicho dinamismo se percibe, por ejemplo, cuando alude, aun salvando su indivisibilidad, a las partes del sacramento y a los frutos que de él dimanan. A sabiendas de que el concilio presenta como parte precisa la contrición, eso no significa que niegue la importancia de otras partes en que se "remitan en algo los pecados sin llegar a la justificación ni a la infusión de la gracia" filial. Es aquí donde refuerza el papel de la satisfacción y de las indulgencias, con las que se satisface la pena que aún resta (cf. DH 1673-1674; 1704-1705).

Siguiendo a Melchor Cano, divide la remisión de los pecados, de forma que: a) se perdone la pena eterna, sin justificar plenamente ni otorgar la filiación adoptiva; b) se conceda el perdón íntegro y perfecto, que hace hijos y herederos. Del mismo modo que ocurre con la contrición, que no hace falta que sea perfecta, los frutos del sacramento tienen un inicio pequeño, y luego llegan a ser mayores, como le ocurrió a Nicodemo (cf. Regla IX, 51v-53r). Así, de la contrición imperfecta cabe esperar que "el Dios omnipotente le da algún fruto, menos o más según su fe, ya que no alcanza la entera remisión de sus culpas" (Regla IX, 53r). La justificación y la filiación, por tanto, no son los únicos frutos del sacramento, porque, si no, la absolución sería, en muchas ocasiones, vana. Expresa un apunte más: así como la eucaristía con devoción dispone (aunque no justifique), lo mismo ocurre con la confesión devota (cf. Regla IX, 53v). Y concluye: "No tenga Vuestra Paternidad por de ningún fruto la absolución que se da con ese inicio de creer y esperar, y algún buen deseo y algún amor, aunque sea pequeñito" (Regla IX, 54r).

Precisamente Pastor de los Cobos dedica la décima regla a la pregunta sobre la indagación del querer y de la rectitud en el ánimo del penitente, aspecto insinuado anteriormente. Porque es un hecho que algunos quieren, pero que dicho querer en el fondo resulta veleidad, y no voluntad firme, abandonando su propósito ante la primera dificultad. En su respuesta, el autor retoma su tesis principal de que, para absolver, el confesor nunca ha de esperar a advertir

${ }^{36}$ Cf. F. Millán, La penitencia hoy... 220-228. 
signos que le generen una "cierta" o "certísima" seguridad objetiva; sino que bastan los indicios de humildad y de cierta enmienda ${ }^{37}$. Entonces, ese querer no se circunscribe a simple nominalismo ni se confunde con mera frivolidad, porque "una cosa es que sea querer flaco y pequeñito, otra cosa que sea veleidad o condicionado" (Regla X, 55v). Como apunte psicológico aduce que la reincidencia se debe a la ignorancia o a la flaqueza ("el peso de la concupiscencia"), y no a la maldad ni a la falsa intención. Tal como esgrime a partir de Lc 8,6-13 y Mt 14,31, no es que se carezca de fe cuando se vuelve a pecar, sino que esta es poca y miedosa. Desde esta perspectiva, valora la pastoral de la "regla trina", de índole rigorista, consistente en que se absolvía por dos veces si no se percibía enmienda, negándose a la tercera. Para Pastor de los Cobos, como cualquier otra norma sobre este sacramento, no es fija, entre otras razones, porque se desconoce la ignorancia y la flaqueza del penitente.

Por último, la undécima regla funge como resumen de todo lo dicho: el autor no puede dar normas fijas para cuestiones de práctica del sacramento debido a la diversidad de personas y circunstancias, lo que requiere desiguales métodos; las dudas que se susciten son ajenas, no propias, ya que el confesor cuenta con la luz de la caridad y del bien del prójimo; las condiciones para una buena confesión son que el penitente venga humilde, pura y fielmente; la caridad del ministro atisba ciertas señales que explican la reincidencia de los pecadores (no ver que es claramente indigno, la ignorancia y la flaqueza), así como claros indicios de que se cree y se desea el sacramento, como son la esperanza, la fe en la salvación, la recta intención, el no venir pecando ni haciendo sacrilegio, el buscar rústicamente el fruto del sacramento...; por el contrario, no expresa malicia el venir aparentemente impasible al sacramento; debe negarse la absolución cuando "o le hará daño al reo, como sucede al que lo recibe pecando o sacrílegamente, o porque se juzga que le servirá al penitente de algún provecho dilatarlo para humillarlo, probarlo, castigarlo, refrenarlo y reprimir su orgullo" (Regla XI, 68r), mas nunca por pensar que alguien está definitivamente cerrado a la gracia, ya que, si aun a los que pecan

\footnotetext{
${ }^{37}$ Considero que en las últimas líneas del folio $55 \mathrm{r}$ el autor sintetiza la tesis principal de su escrito: para administrar la absolución prudentemente basta "solamente con ver, no digo total enmienda, sino aminoradas las culpas, o en algún vicio enmendadas, o que se vio alguna resistencia antes de por fin cometerlas"; porque "ya por reglas de moral se puede creer que trae voluntad y querer verdadero para absolverlo sin escrúpulo". "¿Qué he hecho en todo este escrito? Darle a Vuestra Paternidad a entender que no tiene obligación el confesor a tanto como ver y palpar la contrición y evidenciar la dignidad del sujeto, oliendo que hace los actos precisos, sino que, para dar el sacramento honeste, ordinate et charitative, basta el que vea que el sacramento le será útil al penitente, y por si forte lo merece, no sea que perezca por mi culpa, y porque de negarlo no se espere bien ninguno, y de darlo charitative no hay que temer mal, y además se espera mucho bien". "Que, aunque no vengan enmendados, puede ser que traigan dos cosas precisas, que son creer y querer de veras".
} 
contra el Espíritu Santo, es decir, a los soberbios, se les perdonan los pecados si se humillan, ¿cómo no perdonar a quienes pecan por ignorancia y flaqueza? En resumidas cuentas, el ministro, a la hora de absolver, tiene que creer en que la malicia no es más fuerte que "la infinita caridad de un Dios omnipotente" (Regla XI, 63v).

Terminado este repaso del contenido, no obvio otros aspectos que estimo interesantes del planteamiento teológico del autor. Uno atañe a la asunción de la docrina escolástica defendida por Buenaventura, entre otros, de la institución pneumática de los sacramentos, de forma que él es el que instituye, en el caso concreto de la penitencia, "su uso y frecuencia" (Regla V, 27v, 28r) ${ }^{38}$. Otro refiere a la jerarquía sacramental para aquilatar sus argumentos: si el sacramento del altar, que es el "más augusto", se le administra a indignos, ¿por qué negar el de la penitencia, que es de menor rango? (cf. Regla V, 29r) ${ }^{39}$. Finalmente, su exégesis en absoluto fundamentalista de la Escritura, como se advierte en su comentario sobre el pecado contra el Espíritu Santo (cf. Regla $\mathrm{X}, 63 \mathrm{r})$.

Por otra parte, la exposición de las distintas reglas permite al lector hacerse una idea bastante certera de la teología penitencial del momento y de la recepción de la doctrina de Trento, así como de las diferentes escuelas al respecto y de las cuestiones morales implicadas. Ni que decir tiene que esta panorámica a veces adquiere tintes caricaturescos en virtud de la mordaz crítica con que el autor despacha a quienes piensan distinto de él (encarnados en este religioso escrupuloso) y de la bondad con la que trata, no sin cierta arrogancia, sus propios argumentos ${ }^{40}$. Este desglosamiento, al que se unen sus menciones a Agustín, Jerónimo y Juan Crisóstomo, así como a los grandes compendios jurídicos, hace de su escrito un ejemplo de teología positiva.

Cambiando del fondo a la forma, como destacan sus discípulos, Pastor de los Cobos no cuida la manera de citar, "ni daba estos con terminantes palabras, contentándose con asegurar el sentido, y a veces terminaba con ellos los periodos, dándolos en latín para no defraudar las sentencias de la energía

${ }^{38}$ Cf. J. Granados, Tratado general... 86-87.

${ }^{39}$ Cf. Y. M. Congar, "La idea de sacramentos mayores o principales": Concilium 31 (1968) 24-37.

${ }^{40}$ Solo cito una frase plástica a este respecto que muestra hasta qué punto su discurso llega a la descalificación: "Por ver esa voluntad ser buena; y después de haber creído, y muchas veces a tantos, vuelven y viven perdidos y sin freno... Padre mío, yo también sospecho que este escrito aprovechará a Vuestra Paternidad muy poco, y eso no quita el que tome charitative este trabajo, a lo menos para mí fructuoso, con esperanza de que forte a Vuestra Paternidad le sirva de algo" (Regla IX, 47r). A esto se pueden unir sus comparaciones afrentosas (cf. Regla I, 5r). 
de este idioma"41. Estas pinceladas lingüísticas se perciben en las páginas que siguen. El uso del latín es constante: unas veces, textos enteros; otras, sintagmas; otras, simplemente palabras. Sus referencias a la Escritura (tomadas de la Vulgata), al concilio o a los diversos autores la mayoría de las veces son traídas ad sensum o adaptadas a los periodos castellanos (e incluso a sus propios intereses), lo que torna difícil localizar sus fuentes. Aun con todo, se ha procurado cotejar lo que cita. A lo dicho, cabría añadir su recurso a las preguntas retóricas, a un lenguaje afectado, a un nutrido número de comparaciones y ejemplos, y a múltiples personajes, como si barruntara una teología narrativa.

Por último, por lo que atañe a las normas seguidas en la transcripción de este manuscrito, se ha procurado salvaguardar la escritura tal como la deja el autor. En este sentido, se han respetado la ortografía del momento (alteración de v-b, n-m, y-i, q-c, j-x, g-j, z-c), así como sus sinalefas continuas. Para facilitar la lectura, se han desarrollado las abreviaturas que hemos descifrado, se han añadido entre paréntesis letras o palabras que faciliten la comprensión, se ha procedido a una acentuación moderna de las palabras, se ha intentado adaptar los signos de puntuación a nuestro uso. Se emplea el signo / para indicar la separación de líneas, así como // la de folios, que van señalados en superíndice con las consabidas $r$ (recto) y v (verso). Los cuantiosos subrayados que aparecen en el escrito, la mayor parte de ellos porque se trata de textos latinos, se transcriben en cursiva. Finalmente, no faltan esas palabras que, por diversos motivos, no he sabido interpretar y que se indican con el símbolo (?).

\section{Transcripción}

Respuesta / a un religioso, docto / y timorato, que consul- / tó los miedos, y escrúpulos de su concien- / cia en la Administración del Santo Sacra- / mento de la penitencia a gentes sin temor / de Dios ni enmienda de sus culpas.

Mui Señor mío, / ia ve Vuestra Merced no ser el papel de sus / preguntas capaz de respuestas. Son de práctica de confe- / sionario. Esa es difícil reducirla a pluma, siendo diver- / sa, según son diversas las personas, y estas revestidas / con multiplicadas convinaciones de cosas, y cosas de es- / tas, de aquellas, y las otras circunstancias. La especula- / tiva es más fácil de que ai muchas summas, que preten- / den reducir aciertas reglas la práctica. Una novísima / alemana del docto jesuita Rauter es mui preciosa, pe- / ro siempre es especulativa, ô reglas abstractas. Esta es / ciencia juris; la otra, ciencia facti. Es ciencia juris, aunque / siempre in ordine ad factum. La práctica es ciencia

\footnotetext{
${ }^{41}$ AA. VV., Disertación... VI.
} 
facti / in ordine ad jus. El Jus es fácil, porque se comprehen- / de en las leies, mandatos, cánones, gecretos y en las / glosas, e interpretaciones de los theólogos canonistas. / Todas dirigen al factum, ô son para que los fieles sean dirigi/ dos por ellas ad mores, dignos de la vida eterna. El factum / ô sciencia facti, summamente difícil porque no es cien- / cia ceñida a una cosa fixa, como de molde ô estam- $/ /^{1 \mathrm{v}}$ pilla, sino que se varía longe, late, diverse, según / en cada persona que se confisca, se mudan todas / las cosas. Es verdad que siempre mira en la prác- / tica ad jus, arrimándose ael quanto el factum pudi- / ese ser ordenado, mirando siempre ad aedificationem, y precaviendo la destrucción. Quiero decir que el / factum sea siempre lo que más sirviese al hombre para / su salvación, y no para su perdición. Esta es la mente / de los legisladores; esta es el alma de las leies divinas / y humanas, eclesiásticas y civiles. El acertar / con esa mente de Dios, y de los hombres, en sus leies / es la verdadera ciencia tam juris, quam facti. Pero / ¡quán difícil! Y, no obstante, Vuestra Paternidad me pregunta muchas / cosas de esta práctica; y ia ve mi Padre Maestro que es cosa / no solo ardua, sino imposible, siendo esta práctica di- / versa para cada persona, siendo infinito el Pueblo Cristiano.

Ya me hago cargo que Vuestra Paternidad no me pide lo que su / juicio ve ser imposible explicarse, y que solamente / quisiera unas reglitas prácticas, con las que su ánimo / se dilatara para administrar al Salvador enel confesio- / nario, haciendo esa grande obra con dilatada confianza, / seguridad y anchura. Quisiera mi Padre Maestro saver mane- / jar este oficio como coadjutor de quien instituió los sa- / cramentos y los dispensa por sus sacerdotes, como em/ presa la maior que Dios ideó, por medio de la cruz, qual / es la justificación de las almas para su justificación $/ /^{2 r}$ en la vida eterna. Y ia se ve la alegría que debe / causar en el Ministro que coadjuva â Jesucristo en / tal asumpto. Pero a Vuestra Paternidad le sucede (dice) al contrario, / porque se muele, se cansa, se aflige, y lo peor es que / saca escrúpulo, se turba su conciencia y teme el / castigo del mismo, a quien se le está ministrando con / tanto trabajo, mortificación y charidad, como que fue- / ra más combeniente el no servirlo para darle gusto, / para ser premiado, para evitar su enojo, su castigo, su ene- / mistad, su indignación. ¿Y quién tan creiera sino es un / espíritu tenebroso, que ignora lo que es el sacramento, / su institución, su fin, su virtud, y las grandes ideas del / que lo instituió, para que por él, / como por fuente manantial, / se reparasen unicuique pro suo capro las abismales / riquezas ganadas por el mismo hijo de Dios muerto en la / cruz? Si se administra fideliter el sacramento, sacarán / los místicos después de tanto trabajo, paciencia, charidad, / y tanta mortificación y sufrimiento en tolerar a los malos / y réprobos, que vienen mesclados con los escogidos sien- / do precisa esa mescla en el campo de la Yglesia, no queri- / endo esta por mandato del amo segregar la cizaña del / trigo hasta su tiempo; 
si después, digo, de tolerar tantas es- / pinas que en buenos y malos se experimentan solo / por charidad, y por dar gusto â Dios, se sacara el incurrir / en su enojo, y temer su castigo, se seguirá de ai creer / mal iniquamente de Dios, y decir blasfemamente que el que $/ /^{2 v}$ mandó la administración de ese sacramento y la Yglesia que / manda con todo rigor su práctica â los fieles, y estos que / lo practican frecuentemente, y los predicadores que lo a- / consejan, instan y claman por su frequencia, y los / confesores que ponen esa práctica como provechosa / por penitencia, lo que hacen con ese mandato es po- / ner lazo a los sacerdotes, y anzuelo en que sean presos, / saliendo sus conciencias lazeradas, y sus almas perdidas, / solo por atender aque las de los otros no se pierdan. Se / les manda a los fieles por remedio para su salbación el / que acudan al sacerdote como â juez. Este mandato no / lo pueden cumplir cada uno solo. Es juicio que pasa / entre dos. Es preciso uno que relate su causa, y juez / que la oyga para la sentencia. El cristiano, por una parte, / haze bien en venir, en obedecer, en buscar quien le / oiga; y el juez, el confesor, el sacerdote, ¿haze mal / en oírle, en aiudarle? ¿En darle la mano? ¿En cor- / regirlo? ¿En sanarlo del todo quando el penitente alar- / ga la suia para salir afuera? Ciertamente, si de esa / obra de tanta charidad saca mal el confesor, escrú- / pulo y estrechez, fuera ese mandato y ministerio lazo / y escándalo para los ministros; no misericordia, y corona / de honor por su poder y dignidad.

Vuestra Paternidad vien ve esto, que es verdad; y por eso qui- / siera saver algunas reglas que le sirvieran de luz para ad- / ministrar bien sacramento $\tan$ bueno, de modo que se $/{ }^{\beta r}$ sirva, y se dé gusto â Dios en franquear sus thesoros. / Se le dé al cristiano la mano, y el sacramento que es suio, y para / él se instituió. Se cumpla con la charidad tan man- / dada del próximo, y con el bene facere tan encomendado / por el Salvador aun a los malos y enemigos. Y finalmente / que se dé el sacramento con el orden de devido; esto es, no hacien- / do el sacramento fin, siendo medio, al fin mismo hacerlo me- / dio, porque esto fuera desorden mostruoso, que enoja al / mismo author del sacramento y castigara al ministro por / ignorar la voluntad divina en sus ideas misteriosas. / La salvación del próximo es el fin de los sacramentos. / Estos son medios bien ordenados por Cristo, para ese asum- / pto con promesa de dar muchas gracias a los que no con / fingida feê, buena voluntad y recta intención, quisie / sen participar de la cruz, cuia virtud infinita allí se / oculta, para comunicarse más ô menos, según menos / ô más feê, y buena intención, se llegasen al sacramento / inefable los penitentes. Porque fuera desorden lasti- / moso si, por mirar por el sacramento, faltase el confesor / ala charidad del próximo, siendo esta el fin, y el sacra- / mento, el medio. Si siendo más útil, más comveniente, / de más provecho para algo dar el sacramento al próximo, que / no el negarlo, no obstante, no mirar el sacerdote a este por / mirar al sa- 
cramento fuera, transformar el orden de las / cosas, y agraviar al sacramento mismo, sacándolo de la / razón de medio como fin; y al próximo, a su bien, a su //3v utilidad, a su salvación, mirarlo como cosilla de poca / monta; y después quedar el ánimo con alegría, y con / segura conciencia, como azaña heroica a fabor deel / sacramento, aunque sin edificación, antes quizá con des- / trucción del bien del próximo, â quien se le debe más / miramiento que al sacramento, como que es este medio y fin del próximo.

El no saver Vuestra Paternidad valancear estas cosas / para la segura práctica es (dize) lo que le aflige, le cansa, / le atormenta, dándole horror al confesonario, al que / le teme, añade, como una espada desnuda y afiliada. / Y para su consuelo despachar mucho sin cansancio, / y sin escrúpulo, me pide Vuestra Paternidad alguna luz y remedio, / siendo esas prendas dones del Espíritu Santo. Ni que re- / gla se puede dar en común que sirva para infinitos / incidentes en particular. Si Vuestra Paternidad se contenta con / reglas abstractas, es cosa fácil; pero para la práctica / poco útil; porque lo que sirve para uno, suele dañar para / otro; lo que en una ocasión salió bien, en otra fue un / desatino monstruoso. No obstante, lo que ai eneso de / incombenientes para particularizar la práctica que / dista tanto de generalidades abstractas, diré â / mi Padre Maestro algunas reglas que más convengan al a- / sumpto de su papel, y a las muchas preguntas que con- / tiene, y a las inútiles aflicciones conque se estrecha, se / amarga, se molesta, se escandaliza. $/ /^{4 r}$

\section{Regla I}

El hacer bien hecho ese ministerio del confesionario se / reduze â dispensar el caudal del Amo (y nuestro) con fide- / lidad; esto es lo que se busca inter dispensatores, ut fidelis / quis inveniatur ${ }^{42}$. Con sola esta fidelidad cumplió el / confesor: con ella, aunque el penitente por su culpa no / obra fideliter, el juez oirá gaudenter: Euge serve bone / et fidelis, quia in modico fuisti fidelis intra in gaudium (domini tui) ${ }^{43}$. / Pero Vuestra Paternidad solo mira aque los penitentes sean fieles, can- / sándose, machacándolos inútilmente. Desuerte que sus / angustias, y escrúpulos, son de que los otros no vienen / a su gusto. Y si Vuestra Paternidad lo haze, o no, fideliter, en eso ni aun / duda. Y para quitar todo ese escrúpulo se pone el remedio / de hablar mucho, de afanarse en convertirlos, y de que- / rer oler el dolor; y, sino, negar la absolución. Con / es-

${ }^{42} 1$ Cor 4,12 .

${ }^{43}$ Mt 25,21.23. El autor cambia el 'super pauca' de la Vulgata por 'in modico'. Para el texto de la Vulgata, sigo la versión en línea: http://www.drbo.org/lvb/index.htm. 
tas quatro cosas, y ellas oír solamente a quatro / personas, bregando con ellas toda una mañana, y / aburriendo a los que están deprisa, negándoles el bien de / el sacramento que deseaban recibir, solamente por an- / darse con dilaciones ociosas, para poder oler el dolor / de uno, ô otro, y los demás cristianos (que damos / gracias â Dios de que vengan, y los predicadores los / aterran para que se confiesen) que se vaian enorama- / la rabiosos asus casas, perdida la mañana y familia / por aver aguardado aque Vuestra Paternidad huela el dolor, y con / afrenta, y escándalo, que resulta en detención tan $/ /^{4 \mathrm{v}}$ grande para la gente que espera. ¿Y cómo quiere mi Padre / que se mueba a dolor el que oie con desgana, afrenta / y enfado? El dolor, perla preciosa del Espíritu Santo, / no se quaxa en ira, y enfado, ira viri justitiam Dei / non operatur ${ }^{44}$. Dela ira se saca lo que sacó el sacer- / dote que Vuestra Paternidad me dice, y no obstante el Padre Maestro jus- / ga que el mal está en los otros, y el mal ageno es / el que le da escrúpulo, el horror, el temor como â / una espada desnuda. Pero no le pasa por la idea / el que ese conjunto de cosas interiores tenebrosas / es mal proprio, es falta de fidelidad en el minis- / terio, es trabaxar mucho en que el próximo ven- / ga bien a confesar, y no trabajar en lo que al / confesor únicamente le toca, que es la fidelidad / tan mandada y deseada. Esto se ve claro en el pa- / pel, porque mi Padre solo busca saber de mí re- / glas para oler el dolor, pues con solo eso ia es fiel / Confesor. Demanera que el acierto está â juicio / de Vuestra Paternidad en poder oler al Spíritu Santo entre los hedo- / res de los vicios. No procura Vuestra paternidad oler al Spíritu Santo / en sí proprio, sino en el otro. Por eso, oliéndole los pe- / nitentes â carne, dice que no percibe, ni nada bue- / no huele, loque únicamente le aflige, y por eso quier/ re que io haga, de modo que en aquel muladar he- / diondo se huelan olores y perfumes del cielo con- / que ia vaia Vuestra Paternidad gustoso, y consolado, a su celda $/ /^{5 \mathrm{r}}$ con aver percivido: emisiones, sicut Paradisus ${ }^{45}$. Y / esto en todos, y que sean muchos, y en una ma- / ñana quisiera mi Padre confesar tantas como oie / decir confesamos nosotros, pues oi, dia de San José / (y es mui frequente), yo y mis tres clérigos hemos / despachado casi do(s)cientas personas contadas, sin / faltarles a cada penitente lo que pide, y toca, y le con- / biene, atentis omnibus circunstantiis. Aquí mira / el cuidado de su papel, no el que io le enseñe la fi- / delidad del confesor, sino la de el penitente. La fi- / delidad del penitente es una cosa, y otra la del con- / fesor. Aquel se le enseña su fidelidad quando con- / fiesa. Pero Vuestra Paternidad, para ser fiel confesor, solo pre- / gunta lo que al penitente le toca. Este es su cuida- / do, su angustia y su escrúpulo: ver que vienen / encenagados los otros. Es difícil, dice mi Padre, /

\footnotetext{
${ }^{44}$ St 1,20 .

${ }^{45} \mathrm{Ct} 4,13$.
} 
manejar con acierto el confesionario, por su / asumpto gredoso. ¿Y porqué es difícil y gredoso? / No da Vuestra Paternidad razón seria, sino la agena: Porque vie- / nen, dice, tan encenagadas las almas y envegecidas en los vicios, en especial luxuria consigo y con es- / traños, votos, juramentos, maldiciones, adulterios, / disensiones gravísimas en los matrimonios, quitar fama y honrra, que es un horror oírlos. Esto, dice / Vuestra Paternidad, le aflige, como que esos males impiden al / confesor, que lo haga con los penitentes bien, y que //5v cumpla con fruto, con gusto, y descanso el ministerio. /

Ciertamente si la aflicción fuera de charidad, / fuera bella cosa, como la que tenía San Pablo: quis / scandalizatur, et ego non scandalizator? Quis in- I firmatur, et ego non infirmor ${ }^{46}$ Pero que Vuestra Paternidad / se aflixa como que aquellos males le dañan asu / conciencia, asu empleo, asu ministerio, es / cosa extraña, porque la conciencia no se lacera / sino es quando el confesor falta a lo que le toca, / a lo que puede, y debe hazer con aquel caso, en / aquel asumpto gredoso, dificultoso, ô perdido. / Sepa Vuestra Paternidad lo que le toca. Óbrelo con paz, tranqui- / lidad, charidad, y fidelidad a Dios, y seguramente / esos males que oie y le oprimen, no le harán da- / ño alguno. Como la inundación de las aguas en / tiempo de Noé no dañaron al Arca, antes la / acercaron más al cielo, retirándola más de la / immundicia de la tierra, inqua omnis caro cor- / ruperat viam suam ${ }^{47}$. Mi aflicción, dice Vuestra Paternidad, es / no saber lo que me toca hacer, ofuscado mi ánimo con / tanta perdición, y io digo a mi Padre que el no saver lo / que le toca en esos casos, no es mal ageno, sino pro- / prio. No es ese mal, lo que oie de luxurias y abo / minaciones envegecidas, sino ignorancia pro- / pria por falta de prudencia, de virtud, de no ha- / ver crecido en la feê, en esperanza, ni en chari- $/ /{ }^{6 r} \mathrm{dad}$, por males proprios y vicios envegecidos, quizá / maiores que los carnales, que oie a otros, por ser / vicios Pharisaicos de soberbia, de preferencia, de / concupiscencia: advocari ab hominibus Davi ${ }^{48}$, â / las cáthedras primas in sinagogis ${ }^{49}$, a la ira, â / la venganza, al desprecio de los otros, a la delatación / de la fama y del nombre, dilatando philacteria / sua en escritos, en sermones, en puestos, en / dignidades; a la sujeción de los otros al reino pro- / prio, el que, como con pobreza y austeridad no tiene / aplauso ni grande lucimiento, nace la concupis- / cencia

${ }^{46}$ 2Cor 11,29. Variante: "Quis infirmatur, et ego non infirmor? Quis scandalizatur, et ego non uror?".

${ }^{47}$ Gén 6,12 .

${ }^{48}$ Por el contexto, quizá se trata de una paráfrasis de Mt 23,7: "Et salutationes in foro, et vocari ab hominibus Rabbi”.

${ }^{49}$ Mt 23,6; Lc 11,43; 20,46. 
oculorum sobre la superbia vitae, y la concu- / piscencia carnis ${ }^{50}$, viviendo en la commodidad y re- / galo posible al estado, estorvando solamente lo que pue- / de ser contra el crédito de Maestro de espíritu, que es / el ídolo amado aque se dirige todo aun lo bueno, y mi- / entras asquean a los otros, y ponunt onera impor- / tabilia super humeros hominum; digito autem suo nolunt / ea movere ${ }^{51}$. Pues en verdad que el salvador no asqueó / â las meretrices, ni adúlteras, ni a los ladrones y pu- / blicanos, recibiéndolos a su fee; y tronaba contra los Pha- / riseos, y fulminaba raios de ira, y de amenaza, y repro- / bación: Vae vobis Pharis(a)ei hipocritae ${ }^{52}$, decía, quomodo po- / testis credere, qui gloriam ab invicem accipitis ${ }^{53}$.

Vae nobis, ad suos transierint vitia Phariseorum, / lloraba san Gerónimo. Este miedo sobre mí meda más //6v cuidado enel confesionario, que los dilubios de males / que oigo. Temo no sea que, por ser quizá coram Deo Pha- / risaico, no crea bien, no me alumbre su luz, y de ay, / no sepa obrar con fidelidad; y ciertamente esto es lo que / ai en ese ministerio de cuidado: no los males agenos. / De estos, que no los causo, antes en lo que puedo los curo, / los reprehendo y los perdono, no me hará Dios car- / go; pero sí de los míos, y más si no los veo, ni los corri- / jo, y aun me irrito si soi descubierto, y reprehendido / de otro. El obispo de Laodicea en el Asia, aun siendo / puesto por san Juan Evangelista, era coram Deo / abominable, y él se juzgaba grande obispo y Maestro. / Scio opera tua ${ }^{54}$, le dice Dios, y ve que eres mui malo / solamente con ser tibio; porque utinam frigidus esses, aut / calidus, sed quia tepidus es, (...) incipiam te evomere ex / ore meo ${ }^{55}$. Más valía que fuese frío eum humilitate, as- / queándose assí mismo, disgustado consigo proprio, / con el hedor de los vicios, que tibio eum superbia, y es- / timación propia, por la que se olía â cielo, y â Pa- / raíso oloroso. Porque por la confesión humilde de su / frialdad hallaría commiseración. Pero con la sober- / via de no ser frío como los carnales, ni ser tan malo / velut hic Publicanus ${ }^{56}$ (que oigo y veo a los pies, cubierto / de males y horrores), se juzga limpio, sentado enel / trono, enel tribunal del Magisterio. Y como el ôbis- / po de Laodicea se ve rico Maestro

\footnotetext{
${ }^{50}$ Cf. 1 Jn 2,16 .
}

${ }^{51}$ Mt 23,4. Variante: "Alligant enim onera gravia, et importabililia, et imponunt in humeros hominum: digito autem suo nolunt ea movere".

\footnotetext{
${ }^{52}$ Mt 23,13.14.15.23.25.27.29.

${ }^{53}$ Jn 5,44 .

${ }^{54}$ Ap 3,15 .

${ }^{55}$ Ap 3,15-16.

${ }^{56} \mathrm{Lc} 18,11$.
} 
en la Yglesia y Juez rec- //7r to, que save apartar de sí a los sucios: Recede ame / (dice al asqueroso) quia ego mundus sum ${ }^{57}$. El tibio Pre- / lado Laodicense, aun cargado de males, se juzgaba / rico de virtudes. Dicis, quod debeo sum, et locupleta- /tus, et nul(l)ius egeo ${ }^{58}$. Pero ¡o' quán diferente era el jui- / cio de Dios! Su luz le dixo, y le respondió, quantas ha- / bebat iniquitates, et peccata, et ostendit illi scelera, et / delicta sua ${ }^{59}$. Delitos maiores que los que asqueaba en / los fríos carnales. Eres un ignorante, le dize, y no / sabes quién y quál eres: Nescis quia tu es miser, et / miserabilis, et pauper, et cecus, et nudus ${ }^{60}$. Yo creo que, / si el confesor espantadizo de los males de los seglares / fríos oiera dentro de sí la voz de la luz reprehen- / sora que le descubriera su miseria, su pobreza, su / ceguedad y desnudez de toda virtud, tubiera más hor- / ror de oír de tal boca sus miserias que el horror que / concibe quando oie las abominaciones de los penitentes. / Y assí mismo creo, ô sospecho, que la aflicción que horro- / riza â Vuestra Paternidad en oír a los que confiesa nace de no cono- / cerse, y de querer ponerles remedio fiado de sí proprio, / y por sus esfuerzos, sin fee en la virtud de Cristo, y / sin la esperanza en las promesas de el sacramento, / y sin charidad que omnia credidit, omnia spe- / rat, omnia sustinet ${ }^{6 l}$. Y me pide Vuestra Paternidad que le dé remedio, no / para sus males, sino para remediar a los otros penitentes, que / es lo que le horroriza, y le aflige. Pero io no tengo otro $/ /^{\mathrm{v}}$ remedio que darle que el consejo que el Spíritu de Dios dio al / Ángel dicho de Laodicea: Suadeo tibi emere a(/)me aurum / ignitum probatum, ut locuples fias: et vestimentis albis in- / duaris, et non a(p)pareat confusio nuditatis tuae, et co(l)lirio / inunge occulos tuos ut videas ${ }^{62}$. Este es el remedio de / todas las cosas proprias y agenas: la charidad. Esta / es el oro conque somos ricos, y para emriquer â otros: / ame Vuestra Paternidad a los penitentes, y verá cómo acierta en todo, / en saver decirles, en prudencia para la doctrina, para la / medicina, para no perder el tiempo en esfuerzos inútiles, / en saver por fin

${ }^{57}$ Is 65,5. Así aparece también en el Thesaurus Patrum. Ch.-Gz. (Thesaurus Patrum floresque doctorum qui cum in Theologia, tum in Philosophia olim claruerunt hoc est Dicta sententiae et exempla ex SS. Patribus Probatissimisque scriptoribus collecta et per locos communes distribute cura et opera plurimorum rebus sacris addictorum, Volumen Tertium, Parisiis ex typis Ecclesiasticis Beaucé-Rusand, 1823, 616. Sin embargo, el texto de la Vulgata dice: "Recede a me, non appropinques mihi, quia inmundus es. Isti fumus erunt in furore meo, ignis ardens tota die".

${ }^{58}$ Ap 3,17. Variante: "Quia dicis: Quod dives sum, et locupletatus, et nullius egeo".

${ }^{59}$ Job 13,23. Variante: "Quantas habeo iniquitates et peccata, scelera mea et delicta ostente mihi”.

\footnotetext{
${ }^{60}$ Ap 3,17.

${ }^{61} 1$ Cor 13,7. Variante: "Omnia suffert, omnia credit, omnia sperat, omnia sustinet".

${ }^{62}$ Ap 3,18.
} 
sentenciar, en dar ô negar la abso- / lución siempre en uno ô en otro in edificatione. Y según / lo que más al reo y miserable le combiene, porque cha- / ritas non agit perperam. Audi Pater mi quid Spiritus / dicat Ecclesiis ut docearis fidelitatem in ministro ab eo qui / testis dicit: Fidelis et verus ${ }^{63}$, nombres conque el Salvador / se apellida quando reprehende y exorta al de Laodicea.

\section{Regla 2}

Para tal ministerio es mui preciso formar una su- / blime idea del sacramento, y de su Author que es un Dios / sabio, y omnipotente; idea de sus promesas, de sus pa- / labras, de su verdad, y fidelidad, porque si el confesor mi- / de aquella grandeza con la estricta y aporada idea de / su imaginación, de su sentido, e incredulidad, es preci- / so que, en su exercicio, se estreche, se aflixa, y se excru- $/ /{ }^{8 r}$ pulize, aun quando hizo lo que pudo de su parte. Es me- / mester, pues, feê grande de la virtud del sacramento al / modo de la que tenemos del Baptismo; porque es / como otro Baptismo, pues es, si este la tabla prime- / ra conque el hombre se libertó del naufragio, aquel, / la segunda tabla del remedio. No caben en el pen- / samiento lo que depositó Dios en el Baptismo para / los que creen que, baptizados en agua y sepultados / en ella como en signos, son sepultados in sanguine / Christi ${ }^{64}$, et mortui eum mortuo homine Deo. Y por esta feê / como el Divino Crucificado fue sepultado y resucitó / glorioso del sepulcro, assí el baptizado, si crediderit, / sale resucitada su alma del sepulcro de sus vicios, / anegados estos enel más roxo de la sangre de Cristo; co- / mo salieron libres los israelitas a la orilla, anegadas las / tropas enemigas egipciacas in mare rubro ${ }^{65}$; como in / diebus No ${ }^{66}$, anegados todos

${ }_{63} 1$ Cor 13,4: "Caritas non aemulatur, non agit perperam, non inflator". Ap 3,22: "Qui habet aurem, audiat quid Spiritus dicat ecclesiis". Ap 3,14: "Haec dicit: Amen, testis fidelis et verus".

${ }^{64}$ Ef 2,$13 ; \mathrm{Hb} 10,19$.

${ }^{65}$ Ex 15,4. Es de notar la connotación bautismal que los Santos Padres otorgaron al Cántico de Moisés, teniendo en cuenta la relectura de 1Cor 10,1-2 (cf. Tertuliano, De baptismo 9,1-3, SC 35, 7879; Ambrosio de Milán, De sacramentis I,4,12, SC 25b, 66; Agustín de Hipona, s. 363, PL 39, 16341638; Isidoro de Sevilla, Quaest. in V.T., XV, 2-3; XVI, 1-2, PL 83, 295; De eccl. off. II,25,1, PL 83, 820). Cf. M. Dulaey, Bosques de símbolos. La iniciación cristiana y la Biblia (ss. I-IV), Cristiandad, Madrid 2003, 137-170. La liturgia de la Vigia Pascual sigue otorgándole un puesto preeminente a dicha perícopa veterotestamentaria.

${ }^{66} \mathrm{Cf}$. Is 54,9; Mt 24,37; Lc 17,26; 1 Pe 3,20-21. Esta última cita refiere una lectura expoliativa del diluvio, otro de los grandes iconos bautismales en la patrística (cf. Tertuliano, De baptismo 8,3-4, SC 35, 77-78; Ambrosio de Milán, De sacramentis 2,1,1-2, SC 25b, 74; Agustín de Hipona, c. Faust. 12,17, PL 42, 263). Cf. M. Dulaey, Bosques de símbolos...227-252. 
los vicios, y vicios del mundo, / purificado el mundo con tal agua y Baptismo, salió / limpia y libre la pequeña tropa de justos acercándose / más y más el arca al cielo, mientras más inundaban / las aguas del dilubio. Ahora, aunque nuestro Baptismo es de / tan inefable virtud, como rara vez se da a los adultos en- / cenagados y perdidos, se da sin cuidado ni aflicción, ni es- / crúpulo alguno enel ministro, qual sucede en la confe- / sión, quando vienen encenagados y envegecidos en sus pe- / cados, pero aunquando se daba a los adultos cathecúmenos, se $/ /{ }^{8 v}$ daba sin aflicción, ni amargura; antes eran días festi- / bos, y de alegría universal a la Yglesia, vistiendo a las tropas / baptizadas de gala, de vestiduras blancas que lucían por / toda la Pascual Octava.

Nadie se aflixa. Los ministros mientras más / bautizaban, maior era su alegría por tantos hijos de Dios / que parían al cielo, y a la Yglesia matri filiorum letami. / Pues ¿porqué, pregunto, aflige aora dar el Bautismo de Pe- / nitencia, y no contrista ministrar el de agua? Pues / verdad que el mismo es el que dixo: Qui crediderit et bapti- / zatus fuerit, salbus erit ${ }^{67}$, que quien dixo: Accipite Spiritum / Sanctum, quorum remiseritis peccata, remit(t)untur eis ${ }^{68}$. $\mathrm{Si} /$ el miedo es ver a los penitentes encenagados y envege- / cidos en vicios, no venían mejor al Baptismo mu- / chos de los cathecúmenos pr(a)esertim los que de la genti- / lidad se convertían. En san Agustín avrá visto Vuestra / Paternidad las costumbres que el santo llora en sus cathecúmenos, / de los que muchísimos dilataban el Baptismo más y / más, y algunos no se baptizaban hasta la muerte, en / la que se acudía con prisa para que no murieran sin la / saludable agua. Y ¿porqué esto? Por vivir a su gusto en / vicios, y lograr con facilidad el perdón de todo. Ya se / ve que esto era pura feê y mala cristiandad. Pero, / como viniesen al Baptismo, el santo obispo se alegraba, lo / celebraba y alababa, exortándolos a la vida casta y / cristiana, sin que manchasen las blancas vestiduras. $/ /^{\mathrm{r}}$ Es verdad que no admitía al Baptismo a los que que- / rían proseguir en sus vicios y juntar el cristianismo / que profesaban con la vida vieja de la carne y del mun- / do, que renunciaban al entrar en la Yglesia. Pero lo mismo / sucede aora en la penitencia, la que no damos al que / terco gusta de mantener sus vicios. Mas, como el ca- / thecúmeno que quisiese mudar de vida renunciando la / vida carnal y mundana, lo Baptizava con alegría. / Y aun el agustino cita opinión en su tiempo (opinión le / llama, y no herejía), la que no sigue y abomina, que decía / deverse dar el Baptismo al que lo pidiese, aunque fuese / su vida escandalosa y sin emmendarla. Porque / decían que

\footnotetext{
${ }^{67} \mathrm{Mc} 16,16$.
}

${ }^{68}$ Jn 20, 22. Así lo enseña el Concilio de Trento, en la sesión VI, capítulo 14, y en el c. 3, que dicen: "Accipite Spiritum Sanctum, quorum remiseritis peccata, remituntur eis, et quorum relinueritis, relenta sunt" (I. López de Ayala, El sacrosanto y ecuménico concilio de Trento, traducido al idioma castellano, Sierra y Martí, Barcelona 18287, 68, 170; DH 1542; 1703). 
siempre le haría provecho al hombre unirse / e incorporarse con el fundamento por el cual podían ser / salbos, aunque edificasen sobre el fo(e)num stipulam es / lignum. Se engañaban con el dicho de san Pablo, primera de Chorintios / 3, versículo 12, que dize que Cristo es el fundamento y aliud nemo / potest ponere propter id, quod positum est, quod est Christus / Jesus. Y añade: Si quis autem superaedificat super funda- / mentum hoc, aurum, argentum, lapides pretiosos, ligna foenum / stipulam, uniuscujusque opus manifestum erit: dies enim / Domini declarabit, quia in igne revelabitur: uniuscujusque / opus quale sit, ignis probabit. Si cujus opus manserit quod / superaedificavit, mercedem accipiet. Si cujus opus arserit, de- / trimentum patietur: ipse autem salbus erit, sic tamen quasi / per ignem ${ }^{69}$. Esta salbación, decían, está por el funda- $/ /^{9 \mathrm{v}}$ mento en que estribaban por el Baptismo, aunque sus / obras fuesen malas, que se significaban per foenum, sti- / pulam et lignum. Esta doctrina ya la tiene condenada la / Yglesia contra los Novatores ${ }^{70}$, que dicen basta la feê en Cristo, / aunque las obras sean malas. La Iglesia nos ha ense- / ñado â entender â san Pablo enese su pasage dificul- / toso, y bien pudieran los hereges aver visto, para / no ser engañados, lo que dize el mismo Apóstol al / siguiente verso: Nescitis, quia templum Dei estis, et Spi- / ritus Dei habitat in vobis ${ }^{71}$; este es efecto del Bautis- / mo, y añade: Si quis autem templum Dei violaverit, / disperdet illum Deus ${ }^{72}$. No dize que lo salbará (después que / sus abominaciones ardiesen) por el fundamento, sino que / lo reprobará in aeternum, que eso significa disperdet / illum Deus.

Por esto san Agustín no daba el Baptismo a los / que gustaban de sus vicios, o no querían la vida conti- / nente cristiana, sino que sin dexar la vida munda- / na se llegaban alas aguas salutíferas. Pero como qui- / sieran dexar la mala vida y tomar las costumbres / cristianas, se alegraba más y más quanto maior la / tropa que renacía. Pues ¿porqué, mi Padre Maestro, se aflige / quando es mucha la tropa de penitentes? El sacra- / mento de la penitencia es vice-baptismi. Si llegan ma- / los enfermos asquerosos, mal habituados, lo mismo / sucedía con los cathecúmenos. Si es porque no se ve //10r enimienda, aunque la prometen, en los baptizados su- / cedía lo mismo, aunque el santo obispo se cansaba en / el púlpito para exortarlos. Quien leiere sus sermones / ad Populum verá los males que el santo llora y pondera, / que, comparados con los que aora afligen, se ve que está /aora la Yglesia más gobernada, y con más continencia / por el precepto del confesar, y por la frequencia con- / que

\footnotetext{
${ }^{69} 1$ Cor 3,11-15.

${ }^{70} \mathrm{Se}$ refiere a las doctrinas protestantes y filoprotestantes.

${ }^{71} 1$ Cor 3,16. En la Vulgata, el versículo está formulado como pregunta.

${ }^{72} 1$ Cor 3,17 .
} 
se recibe, que no en los tiempos antiguos, enque / se ve más escasa su usso. Pues ¿qué es lo que aflige â / mi Padre? La inundación de males que experimenta, / dize, sin poder darles remedio, aunque me canso y los / machaco. Dize el adagio: Que el que no quisiere ver lágri- / mas, no vaia a la guerra. No vaia Vuestra Paternidad a los hospitales / si se aflige de ver enfermedades, y llagas horribles. El mé- / dico entra ino se horroriza, y obra loablemente, aunque / vea males de muerte e incurables. No escrupuliza / ni pierde el horror de gran Médico como el enfermo / no muera por su culpa, ô por falta de asistencia cha- / ritativa, ô por ignorancia de lo que le toca. El sacramento / de la Penitencia es piscina salutífera, que tiene virtud per- / manente para salbar, no a uno solo, y que llegase primero, / sino a todos ${ }^{73}$. No se espante Vuestra Paternidad de que acudan enfer- / mos asquerosos rematados. ¿Adónde han de ir? Además, / ¿no se les manda y aconseja que vaian a esa Piscina? ¿No / se les dice que no ai otro remedio ia después del Baptismo? / Pues ¿porqué mi Padre se aflige de que vengan, de que obedez- $/ /^{10 v}$ can, que crean, que pidan al Ángel, que los anegue / en las aguas, creiendo que la sangre de Cristo oculta / es la que los laba, los cura, ô los mexora? El Salba- / dor no asqueó ni extrañó que en la Piscina de Jeru- / salén hubiera multitudo magna languentium, caeco- / rum, claudorum, aridorum ${ }^{74}$. Ni para curar al de 38 / años hizo más que indagar su voluntad y, viendo que / quería ser sano, lo levantó del lecho, con sola la pre- / vención de la emmienda para lo futuro: Noli amplius / pe(c)care, ne deterius tibi aliquid contingat ${ }^{75}$.

De aquí se ve que la estrechez escrupulosa de / Vuestra Paternidad nace del tener poca idea del sacramento o de creer / que el omnipotente que lo instituió para sanidad del mundo / fue en confianza de que, después de 17 siglos (en los que / el sacramento se havía practicado en la Yglesia para mante- / nerse como sobre esa columna), había de venir un tal / Padre Maestro confesor que, con sus esfuerzos, haíncos y estre- / chos achuchos, avían de sanar los enfermos cristianos con / el sacramento. No vemos estos haíncos escrupulosos en / los que ministran a los adultos el inefable sacramento de el / Baptismo aun â los asquerosos como no quisieran ia / sus vicios. Pues ¿porqué Vuestra Paternidad los abomina y con escrúpulos / se acobarda quando, con buena voluntad, piden el / sacramento de la penitencia? Ya veo la diferencia que ai / de uno a otro sacramento, porque el Baptismo es Jubileo / pleníssimo, o indulgencia plenaria, que Dios Padre conce- $/ /{ }^{11 r}$ dió al mundo perdido por el Adán pecador en virtud / del sacrificio de la Cruz, cuia suavidad perfumó el / cielo,

\footnotetext{
${ }^{73}$ Cf. Jn 5,1-9.

${ }^{74} \mathrm{Jn} 5,3$.

${ }^{75} \mathrm{Jn} 5,14$. Variante: "Jam noli peccare, ne deterius tibi aliquid contigat".
} 
y, aplacada la ira divina con tal víctima y holoca- / usto de un hombre justo, y Dios verdadero, como hijo na- / tural y único del Padre celestial, dio perdón general a los / baptizados ${ }^{76}$ (y a otros por otros medios que ignoramos quando / no es culpa suia no recibir el Baptismo pr(a)sertim antes / de instituido en los quatro mil años que precedieron $)^{77}$ para que / el segundo Adán fuese restaurador de la fracción hecha / sin culpa nuestra, no por voluntad propia. Y por la / grande hazaña de Jesucrsito, y por su justicia y agena / voluntad, senos diese de gracia esa plenaria Yndulgencia. / La serpiente engañó al hombre para que comiese el fruto / que pendía del Árbol, el que le pareció aspectu hermo- / so y deleitable. Pero, del mismo modo, nuestro Hombre Dios / se puso en el Árbol, colgó ese fruto dulce y deleitable de la / cruz para engañar a la serpiente y a la muerte su co- / adjutora en la desgracia. Como lo ideó, así sucedió, porque / la serpiente se avalanzó al árbol, desgajó su fruto y / la muerte lo mascó y tragó; pero no lo dirigió ni pudo / tenerlo en el sepulcro sinque saliese victorioso de las / fauces del infierno. Ya lo tenía dicho el profeta: ¡Ô!, mors, ero mors tua, morsus tuus ero, inferne ${ }^{78}$. Salió / de entre los muertos burlada la muerte, soltando ella / la presa que era suia por el decreto contra el géne- / ro humano morte morieris ${ }^{79}$, pero clavándolo en la cruz $/ /{ }^{11 v}$ el segundo Adán, se borra esa sentencia que salió / del Árbol vedado, y en el segundo árbol se escribió /

${ }^{76}$ Véase la doctrina anselmiana de la satisfacción (cf. E. Briancesco, "Lenguaje hipostático y satisfacción redentora en san Anselmo": Patrística et mediaevalia 12 (1991) 33-51; O. González de Cardedal, Cristología, BAC, Madrid 2001, 296-302; R. J. Daly, "Images of God and the imitation of God: Problems with atonement”: Theological Studies 68 (2007) 36-51; J. M. Goyarrola Queralt, "La categoría de la satisfacción en la obra Cur Deus homo de san Anselmo": Nova et vetera 87 (2019) 57-72).

${ }^{77}$ El autor defiende la existencia de la salvación más allá de los límites de la Iglesia institucional, es decir, más allá de la recepción del bautismo sacramental. La doctrina tradicional habla de otros tipos de bautismo, que no son el del agua, como el de deseo (cf. DH 788; 1604; Agustín de Hipona, bapt. 4,14,21, PL 43, 167-168; Tomás de Aquino, Summa Theologica III, q. 69, a. 4, ad 2) y el de sangre (cf. Mt 10,32.39; Cipriano de Cartago, Ad Fortunatum Praef. 4, CCSL 3, 184-185; Epistola 77,2,2, CCSL 3/3, 619; De domenica oratione 24, CCSL 3/1, 106). Cf. CEC 1258-1261. Asimismo, junto a la interpretación moderada del extra ecclesiam nulla salus a raíz del descubrimiento de América, la teología asume el postulado eclesiológico agustiniano de la Ecclesia ab Abel (cf. Agustín de Hipona, s. 341,9,11, PL 39, 1499-1500; 4,11, PL 38, 39; ep. 102,12.15, PL 33, 754.756; en. Ps. 142,3, PL 37, 1846), complementario a la doctrina del Christus totus (cf. Agustín de Hipona, en. Ps. 30,II, s.1,4, PL 36,232; 37,6, PL 36, 399-400; 74,4, PL 36,948-949). Cf. F. Sullivan, ¿Hay salvación fuera de la Iglesia? (Bilbao, DDB, 1999), 39-56; S. Madrigal, "Eclesialidad y universalidad de la salvación a la luz de la noción Ecclesia ab Abel": P. Rodríguez Panizo y X. Quinzá (eds.), Cristianismo y religiones (Bilbao, DDB, 2002), 271-322; G. Tejerina Arias, "La eclesiología agustiniana del Christus totus": Revista Agustiniana 42 (2001) 1139-1179.

${ }^{78}$ Os 13,14 .

${ }^{79}$ Gén 2,17. 
otra: morte vives, para que la tropa resucitada por / el Baptismo cante el mote alegre: Ubi mors vic- / toria tua? Ubi est stimulus tuus? ${ }^{80}$. Salió el engaña- / dor divino, Primogenitus mortuorum ${ }^{81}$, a vida eterna, dan- / do a los fieles desde luego el Spiritu de vida que los / resucite de la culpa, y con promesa asu tiempo (to- / dos juntos) de unificar el cuerpo mismo, para que sea / completo el triumpho de el resucitado: Et ego, dice, / resuscitabo eum in novisimo die ${ }^{82}$; qui sermonem meum serva- / verit, mortem non gustabit in aeternum ${ }^{83}$. Esta indulgencia / plenaria y remisión de todas las culpas es de gracia, / por justicia agena sin satisfacción propria, admiti- / endo el Juez la paga del fideijustificador y fiador del caudal / de su sangre y vida, pagando los deudores acosta / agena. Esta gracia se da en el Baptismo; pero en / el sacramento de la penitencia, aunque es como Bap- / tismo, ô la segunda tabla en que evadimos el naufra- / gio de los pecados, sucede la cosa de otro modo.

Es assí que, perdida la gracia tan pasmosa y / dádiva de tanta indulgencia y ganada a tanta costa / (cosas ciertamente inefables), era razón por tal ingratitud / que no hallara el hombre remedio en el mal, no ia / ageno, sino proprio, y voluntario. Assí lo creieron al- / gunos, reusando dar penitencia a los que, ia cristianos, //2r volvían al vómito. Se movieron a este rigor del otro dicho de / san Pablo: Voluntarie enim peccantibus nobis post ac- / ceptam notitiam veritatis, iam non relinquitur hostia pro / peccatis. Terribilis autem quaedam (ex)spectatio judicii, et ignis / aemulatio, quae consumptura est adversarios ${ }^{84}$. Asssí mismo / de otro dicho del capítulo 6, versículos 4, 5, 7: Impo(s)sibile est eo: qui semel / sunt illuminati, gustaverunt etiam donum caeleste, et partici- / pes facti sunt Spiritus Sancti, gustaverunt nihilominus / bonum Dei verbum, virtutesque saeculi futuri et prolapsi / sunt; rursus renovari ad poenitentiam ${ }^{85}$. Con esto quizá mi / Padre Maestro se afligirá mucho, y se pondrá más escrupulo- / so, y no hay para que se aflixa el confesor haciendo su / officio bien hecho; porque contra ese santo exercicio no / trae cosa ninguna san Pablo. Algunas Yglesias antiguas, / por esos dichos de la Carta a los Hebreos, tardaron mu- / cho en creer ser de san Pablo, y sino nimis seró no / la admitieron

\footnotetext{
${ }^{80} 1$ Cor 15,55 . Variante: "Ubi est mors victoria tua? Ubi est mors stimulus tuus?”.

${ }^{81}$ Ap 1,5 .

${ }^{82}$ Jn $6,40.45 .55$.

${ }^{83} \mathrm{Jn} 8,52$.

${ }^{84} \mathrm{Hb} 10,26-27$.

${ }^{85} \mathrm{Hb} 6,4-6$. Variante: "Virtutesque saeculi venturi et prolapse sunt". Adviértase que el autor cita erróneamente la numeración de los versículos.
} 
por escripta canónica ${ }^{86}$. A Novato y / Novacianos ${ }^{87}$ les sirbió de tropiezo ese dicho Apostólico, / porque negaban la penitencia a los que pecaban después / de el Baptismo. Pero fue en Nobato â buscar de / el sagrado Texto, porque no negaba este herege la peni- / tencia coram Deo acuia misericordia dexaba â / los pecadores baptizados, y solamente decía que la Yglesia / no los podía admitir a la penitencia, ni por más ar- / repentimiento y castigo podían ser más admitidos / a la comunión de los fieles, ni a los sacramentos, //12v ni ad societatem cristianorum. Pero la Yglesia enseña otra / cosa explicando al Apóstol en sentido lexítimo.

No obstante, en los primeros siglos algu- / nas Yglesias particulares hacían lo mismo con los peca- / dores post baptismum; pero no en todos los pecados, sino / en crímenes gravísimos, como la apostasía, adulte- / rio, homicidio. Aestos los dejaban (sin remedio de la Yglesia) a la divina misericordia, que no tiene límite por parte / ninguna ${ }^{88}$. Porque juzgaban aquellos prelados

${ }^{86}$ Recuérdese que la carta a los Hebreros no era admitida como canónica por los protestantes, y que fue el Concilio de Trento el que fijó el canon bíblico de la Iglesia Católica en la sesión IV del 8 de abril de 1546 (cf. DH 1501-1508).

${ }^{87}$ Novaciano (Novacio) fue un sacerdote romano, de origen frigio, del siglo tercero que, tras la persecución de Decio y vacante la sede romana, se postuló a ocuparla, junto con Cornelio. Saliendo este elegido, aquel lo acusó de laxismo moral por haber promovido, a través de una penitencia pública especial, la readmisión de quienes apostataron de la fe durante la persecución para salvar su vida. Novaciano defendía que la Iglesia no tenía poder para perdonar pecados como este. Ante la indiferencia a sus postulados, Eusebio de Cesarea afirma que, sirviéndose de malas artes, se hizo consagrar obispo de Roma. Lo cierto es que, convocado un sínodo de obispos italianos por Cornelio en el 251, se lo condenó como cismático y se lo excomulgó. Reuniendo a un grupo de adeptos, erigió la "Iglesia de los puros", que defendía la carencia de facultad eclesial para perdonar pecados como la apostasía, proponía un segundo bautismo para los lapsi y propugnaba la invalidez de los sacramentos del bautismo y de la penitencia administrados por ministros pecadores (cf. A. Piñero Sáenz, Los cristianismos derrotados, EDAF, Madrid 2007, 274-280; F. A. Adrien Pluquet, Diccionario de las herejías, errores y cismas, V, Imprenta de la Viuda de Palacios e Hijos, Madrid 1850, 159-163). Novato, por su parte, fue un presbítero cartaginés que, junto con Felicísimo, se rebeló contra Cipriano, acusándolo de excesiva dureza con los lapsi. Excomulgado, escapó a Roma y se unió a la Iglesia cátara, con lo que asumió unas tesis contrarias a las que defendía en África (cf. J. Alzog, Historia universal de la Iglesia, I, Imprenta Pablo Riera, Barcelona 1868, 325-326). Algunos autores confunden ambas identidades, algo que quizá ocurra en esta obra.

${ }^{88}$ De nuevo el autor argumenta desde la convicción de que la institución eclesial y sacramental no agota el torrente de la gracia divina. En parte, este es uno de los elementos que la teología contemporánea salvaguarda al acuñar el concepto fundamental de 'sacramentalidad', y comprender el sacramento como realidad simbólica (cf. V. Botella Cubells, Sacramento. Una noción cristiana fundamental, San Esteban, Salamanca 2007, 25-28, 103-109; L. M. Chauvet, Símbolo y sacramento, Herder, Barcelona 1991, 159-162; I. Oñatibia, "De la dialéctica al símbolo. Un giro importante en la teología de los sacramentos": Estudios eclesiásticos 56 (1981) 1399-1431; A. Novoa Cid Fuentes, “Comunicación simbólica y sacramento": Compostelanum 45 (2000) 199-125). 
no era / conveniente ni decente admitir con externa reconcilia- / ción asu seno a los que per tantum nefas sanguinem fede- / ris palluissent. Y habían menospreciado el Spíritu gracioso / que recibieron en el Baptismo. Este rigor no era del / gusto de Cristo, cuio Spíritu, todo benignidad y manse- / dumbre, dio su vida por los pecadores, y dice: Non veni / vocare justos; sed peccatores ${ }^{89}$. Y a los Apóstoles, que querían / bajase fuego del cielo contra los incrédulos, los repre- / he(n)dió sobre su zelo, que no era del Spíritu de Dios: Nes- / citis cuius Spiritus sitis ${ }^{90}$. Y assí se vio en los que tubieron / este rigor caídas horribles en heregías, apartándose / de la Yglesia. Tertuliano ${ }^{91}$, hombre tan grande y defensor de / la feê en sus escritos y apologías, se disgustó y separó de / la Yglesia de Roma porque esta daba penitencia a los Adultos, / y le pareció mexor la Iglesia y rigor de Montano, haciéndose / montanista ${ }^{92}$. Lucifero, autor de los luciferianos, no quería / admitir a los herejes que se volvían a la Yglesia ${ }^{93}$. Ôtros Padres $/ /{ }^{13 r}$ daban penitencia, pero una vez sola. Assí como

${ }^{89}$ Lc 5,32.

${ }^{90}$ Lc 9,55. Variante: "Nescitis cuius Spiritus estis".

${ }^{91}$ Tertuliano (Cartago, c. 155-c. 230) fue el primer gran exponente de la reflexión teológica latina. Pagano de nacimiento y educación, y proveniente del ámbito del derecho, una vez convertido, entre el 190 y el 195, adaptó al latín, con eficacia y propiedad, la terminología y densidad teológicas con las que la tradición griega había desarrollado las doctrinas cristológica, trinitaria, sacramental... De temperamento apasionado, se convirtió en uno de los grandes apologistas de la Iglesia africana, ya frente a los judíos, ya ante los paganos, especialmente el gnosticismo, y, por ello mismo, a partir del 213, y tras nueve años como simpatizante, se separó de la Iglesia católica y se adhirió al montanismo, que lo satisfacía por su propuesta rigorista. Aun con todo, insatisfecho por el cariz oriental de la secta, fundó su propio movimiento, el tertulianismo (cf. G. Laiti, "Tertuliano": Cristianismo. Diccionario enciclopédico san Pablo, San Pablo, Madrid 2009, 923-924; C. Á. Balaguer y J. M. Serrano Galván, "Introducción": Tertuliano, A los mártires; El escorpión; La huida en persecución, Ciudad Nueva, Madrid 2004, 7-15; S. Vicastillo, "Introducción al autor": Tertuliano, Prescripciones contra todas las herejías, Ciudad Nueva, Madrid 2001, 13-27).

${ }^{92}$ En el siglo V recibió el nombre de 'montanismo' una 'nueva profecía', de corte milenarista y extática, derivada del cristianismo joánico y fundada en Frigia, hacia el 172, por Montano, natural de Ardabán y antiguo sacerdote de Cibeles, quien afirmaba ser el Espíritu Santo prometido por Jesús (cf. Jn 14,26; 16,7). Dicho movimiento se extendió por Asia Menor, la Galia, Roma y el África cristiana. Debido a su escatologismo radical, afianzado por la peste y los terremotos que sacudieron la zona en el decenio de los sesenta del siglo segundo, se caracterizó por su rigorismo. Promovió el martirio (con la consiguiente renuncia exagerada al mundo), prohibió las segundas nupcias e incluso el matrimonio, propuso una acentuada ascética (con duros y prolongados ayunos), condenó la apostasía a causa de las persecuciones (alentando que los mismos cristianos denunciaran a quienes lo hacían) y rechazó perdonar a los culpables (cf. A. Zambarbieri, "Montanismo": Cristianismo... 672; C. Á. Balaguer y J. M. Serrano Galván, "Introducción... 29-34).

${ }^{93}$ Bajo el nombre de Lucifero se esconde Lucifer de Cagliari, obispo de esta localidad de Cerdeña, probablemente desde el año 353 hasta su muerte, acontecida en el 370. Participó en el Concilio de Milán del 355 como legado pontificio de Liberio, decantándose a favor de Atanasio de Alejandría y 
el Bap- / tismo no se podía reiterar, así el de la penitencia se daba una / vez sola. Mucho se ve y se oie en lo antiguo de que la penitencia se / debe dar una vez sola. No debe Vuestra Paternidad ni por esto afligirse; por / que esta práctica de la penitencia una vez sola se sabe que era / de la penitencia solemne y pública, y reconciliación externa / con la Yglesia en gravísimas culpas; y, aunque oi vemos algún / rasgo de ese uso en los crímenes de Apostasía y heregía, â / los que se arrepienten y piden misericordia y penitencia, / la da con benignidad el Santo Tribunal, como adjuren y de- / testen los crímenes y abominaciones; la da y absuelbe / públicamente con la penitencia conveniente. Pero una vez no más, no dos. Pues a los relapsos en los delitos mismos, los niegan / otra penitencia pública y los relaxan a la potestad secular, / la que les da aun pena más terrible que la antigua de / los cánones, quales la muerte. Pero, aunque les niegan los sa- / cramentos y la comunión, pero no el de la penitencia, en que se ve / que la Yglesia no excluie a nadie del sacramento si lo quiere y / lo pide con la segura creencia que es la segunda tabla. / En los otros delitos gravísimos, la potestad civil toma oy a su / cargo poner penitencias, como en adulterios públicos / ó denunciados homicidios, falsarios y latrocinios, reser- / vando así los Obispos los que son contra los sacramentos y / de sujetos eclesiásticos.

Con ambas Potestades se govierna la Yglesia en lo pú- / blico, en lo exterior y en el fuero externo, pero sin que se $/{ }^{13 v}$ toque en nada contra el sacramento de la penitencia, que es ju- / dicatura de misericordia, como Piscina y segundo Baptismo, / instituido para remedio de flacos. Es así que, aunque el Bap- / tismo fue y es un don inefable, digno de averse mere- / cido por sola la muerte del Cordero de Dios Inma- / culado. Pero, como dando el Baptismo

en contra de las tesis arrianas. Este hecho provocó que el emperador Constantino II, proarriano, disolviera el concilio y exiliara a Lucifer, quien durante los siguientes siete años vivió entre Siria y Tebas, y escribió cinco libros. Restituido en su diócesis por el emperador Juliano en el 362, la purificó de las tendencias arrianas y, en el Concilio de Alejandría de dicho año, se opuso a readmitir en la fe católica a los obispos que, por debilidad, habían profesado las tesis arrianas en los concilios de Rémini y Seleucia. Como solución a la división que se vivía en la Iglesia de Antioquía, pasando por esta ciudad en su regreso del destierro, consagró obispo a Paulino, medida que dificultó aún más la situación eclesial en la zona y que fue desaprobada por san Dámaso, san Hilario de Poitiers, san Atanasio o san Eusebio de Vercelli. A partir de entonces, rompió con estos, a quienes acusó de semiarrianismo por admitir a los obispos arrepentidos, y asumió posturas rigoristas en este sentido. A su muerte, sus discípulos, denominados luciferianos, entre los que destacan los clérigos de la Iglesia romana Hilario y Faustino, se caracterizaron por su defensa ardiente del Concilio de Nicea y por una exageración del rigorismo, exigiendo rebautizar a los cismáticos y herejes (cf. T. Kauhanen, Lucifer of Calgliari and the Text of 1-2 Kings, SBL Press, Atlanta 1978, 5-6; A. Alba López, "El cisma luciferiano": G. Bravo y R. González Salinero (coords.), Minorías y sectas en el mundo romano, Signifer Libros, Madrid 2006, 177-192; J. Pérez Mas, La crisis luciferiana: un intento de reconstrucción histórica, Institum Patristicum Augustinianum, Roma 2008). 
tanta gracia, / aún no quita la concupiscencia e ignorancia (aun- / que las aminora y da virtudes contra ellas) dexadas ad / agonem, y para que el hombre tenga más gloria, gana- / da la corona eterna con las grandes virtudes, / sucede que los más por flacos soldados, y por que cum dormirent homines ${ }^{94}$ y se descuidasen en la custo- / dia de tal perla se ensucian más, y más se empeo- / ran, que antes eran malos, et fiunt novis(s)ima baptizati pejora prioribus ${ }^{95}$. Por esto fuera apurada y reducida / a pocos la gracia de la cruz e indulgencia del Baptismo, / si los caídos después no hubieran remedio. Es, pues, / honor y excelencia de la cruz el segundo Baptismo ô / segunda tabla de la penitencia. Por esto, este sacra- / mento es mui parecido al de el agua en la virtud in- / mensa de dar gracias y perdonar culpas, de justificar / al hombre pecador, bolbiéndole la estola primera de la / gracia, y dándole al Spíritu Santo por el que se seaijó ${ }^{96}, \mathrm{y} /$ por eso heredero del Reino. Es, pues, preciso creer / mucho de la virtud y promesa del Salvador al sacramento / para administrarlo, no con amargura escrupulosa, sino con $/ /{ }^{14 \mathrm{r}}$ deliciosa alegría, como se da sin escrúpulo amargo el / Baptismo.

${ }^{94} \mathrm{Mt} 13,25$. Este versículo se convirtió en una proclama antivaldense durante el medievo, especialmente en Alemania, que encuentra su punto de inflexión en los Concilios de Constanza (14141418) y Basilea (1431-1438) (cf. G. M. M. Van Dussen and P. Soukup, The Anti-Waldensian Treatise Cum Dormirent Homines: Historical Context, Polemical Strategy, and Manuscript Tradition, Brepols Publisher, Turnhout 2013, 358). En el barroco español, por el contrario, este versículo evangélico da lugar a obras homiléticas, en las que se expresan las preocupaciones propias de la oratoria del momento. Cercano a Pastor de los Cobos es José de Barzia y Zambrana, autor de una recopilación en tres volúmenes titulada Despertador Christiano de sermones doctrinales, Francisco de Ochoa, Granada 1678, obra de gran acogida entre el público, tal como denotan sus múltiples ediciones, lo que propició el aumento de los volúmnes y que él mismo escribiera un Compendio del Despertador christiano, Juan García Infanzón, Madrid $1691^{3}$. De Bercia, natural de Málaga, fue canónigo de la Iglesia del Sacromonte y catedrático de Sagrada Escritura de las Escuelas, Canónigo de la Iglesia de Toledo, Prior del Real Priorato de Santa María de Sar y predicador de su Majestad. Su obra contiene sermones doctrinales que abordan cuestiones como el pecado mortal, el sacramento de la penitencia y diversos temas escatológicos, siendo su propósito la conversión de los oyentes (cf. A. Morgado García, La diócesis de Cádiz. De Trento a la desamortización, Universidad de Cádiz, Cádiz 2008, 252-259; P. Rueda Ramírez y M. Fernández Chaves, "El terremoto como noticia: relaciones de sucesos y otros textos del temblor de 1680": Estudios sobre el Mensaje Periodístico 14 (2008) 585). O los sermones de adviento de Francisco Ignacio de Porres, Discursos morales, para los domingos de adviento, y del año, María Fernández, Alcalá 1645.

${ }^{95} \mathrm{Mt} 12,45$. Variante: "Fiunt novissima hominis illius pejora prioribus".

${ }^{96} \mathrm{El}$ autor destingue los diversos niveles de la gracia, tan propios de la escolástica y neoescolástica, al tiempo que debatidos en los ss. XVII y XVIII, tal como muestran la disputa de auxiliis y la cuestión jansenista (cf. J. L. Lorda, La gracia de Dios, Palabra, Madrid 2004, 303-328; A. Ganoczy, De su plenitud todos hemos recibido (Barcelona, Herder, 1991), 252-257). Sobre los diversos niveles y dimensiones de la gracia, cf. J. L. Ruiz de la Peña, El don de Dios, Sal Terrae, Santander 1991, 315-370, 372-384. 
Solamente le puede al Padre Maestro causar el escrúpulo la / diferencia que ai del Baptismo de agua al de la penitencia. / Es assí que quien recibió el Baptismo por satisfacción age- / na, y por méritos del Cordero sacrificado en la cruz, y / asado al fuego de la charidad, con dolores y tormentos, / no recibirá el de la penitencia sin satisfacción propria; / porque, perdida tanta gracia por voluntad propria, ya es / preciso que el pecador baptizado faciat fructos dignos / penitentiae ${ }^{97}$. De aquí vinieron las pentiencias rigoro- / sisimas antiguas determinadas por los Cánones / contra los baptizados pecadores. Es precisa, pues, ia sa- / tisfacción propria para que, unida con la de la cruz, se al- / canze la indulgencia de la segunda gracia. Y ¿qué vemos oy? Esto / aflige a Vuestra Paternidad, y más si compara la práctica de la anti- / gua Yglesia con la de la ahora en infinita tropa sin dolor, / sin enmienda y sin penitencia alguna. Y io le digo / que es menester creer mucho de la virtud del sacramento / para darlo sin amargura en medio de las miserias.

\section{Regla III}

No es buena regla para la práctica de el sacra- / mento la antigua de la Yglesia, sino es la feê establecida / en el Tridentino sobre este sacramento. Es assí que la / Iglesia aido creciendo sicut aurora consurgens $^{98}$, y oi está /14v como sol en medio día, ô en el Zenit de su luz. Por esto se ha / conocido más de el sacramento de la pentiencia. Para su / práctica se ha mandado su uso. Aconseja su fre- / quencia. Los fieles buenos y malos lo practican con / utilidad provechosa. Los ministros lo administran con / laudable trabajo y mérito del premio prometido al / fiel sierbo. Se ha entendido el pensamiento de Jesu- / cristo en haberlo instituido, y dexado a la Yglesia tal / tesoro. Se save explicar los lugares de la escriptura / que parece quitan la esperanza de la penitencia; sin- / gularmente los dichos de san Pablo a los Hebreos; y, en / quanto a la satisfacción y penitencia, se ha dado con- / veniente méthodo para la práctica.

Es assí que, sin que estorve la doctrina de / san Pablo, con el mismo Apóstol, savemos ciertamente / seis cosas: la $1^{\text {a }}$, que el Baptismo no se puede segunda / vez reiterar; la $2^{\mathrm{a}}$, que Cristo no puede morir dos veces; / la $3^{\mathrm{a}}$, que los delitos mui graves después del Baptismo / no se pueden remitir si no es con ficitultad; la $4^{\mathrm{a}}$, que no / ai delito, por máximo que sea, que non valeat expiari, / sino es en la desesperación, è impenitencia final; la / $5^{\text {a }}$, que en la ley de Moysés no ai víctimas algunas que / sean capazes para expiar delitos y pe-

\footnotetext{
${ }^{97}$ Lc 3,8. Variante: "Facite ergo fructus dignos poenitentiae".

${ }^{98}$ Cant 6,9.
} 
cados; la $6^{\mathrm{a}}$, que el / único camino que resta para alcanzar la remisión de / los pecados después del Baptismo es el sacramento de / la penitencia. Por eso, la Yglesia a nadie le cierra esa $/ /{ }^{15 r}$ puerta, y al que la pide con buena voluntad, se le fran- / quea la entrada. Con esta verdad se ve que san Pablo no / habla contra el sacramento de la penitencia, y a otra cosa / mira su enseñanza. Se ve que habla de delito particul- / lar, no de todos en común: Voluntarie enim nobis pecanti- / bus (dice) post acceptam notitiam veritatis iam non relinquitur / pro pecatis hostia ${ }^{99}$. El Apóstol se ve que habla del pecado / de apostasía, porque en el verso antecedente dice: Non de- / sendam esse col(l)ectionem nostram ${ }^{100}$, y da la razón: porque, si assí / sucediera, iam relinquitur hostia pro pecatis.

Escribe a los hebreos, y si esto(s) se buelben al Ju- / daísmo, ia no tienen hostia ninguna para labar tal man- / cha; porque ni Cristo les vale, al que han renunciado, / ni las hostias y sacrificios antiguos, por estar ia abr- / rogados, ni otro Mesías futuro, que no ai otro más / que Jesucristo, ni ay esperanza de que Jesucristo bu- / elba más, ni otra vez â morir: Christus resurgens ex mor- / tuis, iam non moritur: mors illi ultra non dominabitur. Quod enim / mortuus est peccato, mortuus est semel ${ }^{101}$. Esta apostasía es de / la que el Apóstol habla, y siempre de qualquiera pecado que / hable el Apóstol habla de su imposibilidad para la expiación / more humano, esto es, de lo que se llama imposible entre los / hombres, qual es lo que es sumamente difícil. Por eso decir / non relinquit hostia quiere decir agre, et vix relin- / quitur hostia ${ }^{102}$, que expíe tal apostasía, porque estos apóstatas son / ciertamente indignos de indulgencia, porque, con cierta ciencia y conocida $/ /^{15 \mathrm{v}}$ ia la verdad, y con venenosa malicia, con su infideli- / dad e ingratitud abrazan las fuentes de la divina miseri- / cordia para darles la gracia de la penitencia.

Muchos Santos Padres, entre los quales san Juan Chrisóstomo / y el Ambrosio, construien al Apóstol, como que habla de / el Baptismo, como si dixera: Nullus relinquitur eis / iam baptismus. Porque el Baptismo es figura de la muerte / de Cristo, que fue la hostia única pro pec(c)ato, y assí, volun- / tarie pec(c)antibus, ya no pueden ser limpios alo (aliis) bap- / tismo, sicut neque alia Christi morte expiari po(s)sunt. Pe- / ro este sentido parece que excluie

${ }^{99} \mathrm{Hb} 10,26$.

${ }^{100} \mathrm{Hb}$ 10,25. Variante: "Non deserentes collectionem nostram".

${ }^{101}$ Rom 6,9-10a.

${ }^{102}$ Así se comenta el iam non relinquitur pro peccatis hostia de Heb 10,26 en la Biblia sacra vulgatae editionis Sixti V Pontificis maximi iuffu recognita, et Clementis VIII auctoritate edita, cum selectissimis Litteralibus Commentariis, Tomus XXVII, Modestus Fentius, Venetiis 1757, 226: "Id est, agre et vix relinquitur hostia pro peccato, qua peccatum illud expietur, tum quia tales apostatae plane indigni funt venia, licet auxilia sufficientia illis non, denegetur; tum quia fua certa malitia, et infidelitate claudunt fontes divinae misericordiae". 
del remedio del sacra- / mento de la Penitencia; porque san Pablo no les dexa re- / medio alguno, sino terribilis, quaedam (ex)spectatio judicii ${ }^{103}$. / Por eso, mexor otros Padres entienden este dicho apostólico de / todos los gravísimos delitos pr(a)esertim de la apostasía y / abnegación de la feê y religión cristiana, quando alguno / voluntariamente de intento y de malicia, y aun con- / tra su conciencia, se aparta a corpore Ecclesiae, im- / pugna su doctrina, calumnia sus costumbres, las murmu- / ra y escandaliza, y segrega a los fieles miembros de ese / cuerpo, sembrando seísmas y discordias. De este peca- / do, dizen, habla Jesucristo contra los fariseos impugna- / dores de la verdad, atribuiendo sus milagros â Belcebud, / quando dixo que el pecado contra el Spíritu Santo no se remitía / neque in hoc saeculo, neque in futuro ${ }^{104}$.

No obstante, obligados los Prelados de algunas $/ /{ }^{16 r}$ particulares iglesias, de el terror de este lugar de san Pablo, / no daban penitencia â los mui graves crímenes. A estos los / desechaban â caetu fidelium, et a comunione sacramentorum, / dexando sus causas a la divina misericordia, como que no ca- / bían tales culpas en las llaves de la Yglesia, aunque Cristo Jesús / no puso límite quando entregó asu iglesia las llaves mismas, di- / ciendo universalmente que, cumque solveritis in terra, erunt soluta et in caelo ${ }^{105}$. Además, los pecados que absolbían eran / castigados con terribles castigos. Por estos los fieles huían de / la confesión, contentándose con la que hacían en secreto / â Dios. No había aún, con esa rigorosa disciplina, precepto de / confesar â tiempo determinado. Sucedía con la commu- / nión entonces lo que ahora con la confirmación, y ô- / tros sacramentos de vibos, en los que, aunque piden estar el que los recibe en gracia, pero como con la confesión y peniten- / cia interna se justifican, no ai mandato de que preceda / precisamente el sacramento de la Penitencia, excepto la eucaristía, / sobre la qual la Yglesia manda que, para recibirla el que pecó gra- / vemente, por más contrito que se juzgue y crea que por tal peni- / tencia recibió la gracia, no obstante, se le manda que prece- / da ala sumpción Eucarística el sacramento de la Peni- / tencia ${ }^{106}$. Por esto se ve en lo antiguo poco uso de este sacramento. / Y en los redicadores y santos obispôs, como san Juan Chri- / sóstomo, se oie clamorear a los pecadores, que exortándolos, / extrechándolos, urgiendo y atterrándolos, para que hagan e- / nitencia coram

${ }^{103} \mathrm{Hb} 10,27$.

${ }^{104} \mathrm{Mt} 12,32$.

${ }^{105}$ Mt 18,18. Variante: "Et quaecumque solveritis super terram, erunt soluta et in caelo".

${ }^{106}$ Explicación de la práctica sacramental del entonces. Además de mostrar el orden que se seguía en la administración de los sacramentos, también señala la circularidad existente entre Eucaristía y Penitencia, así como la doctrina según la cual no basta con la contrición perfecta para adquirir el perdón, sino que esta debe ir acompañada por el voto del sacramento. 
Deo, para que lloren, clamen, pidan y se //16v justifiquen. De aquí es que la penitencia interna es la / que tenía el gran crédito en la Yglesia y poca fama te- / nía el sacramento de la Penitencia. Pero oi la tiene grandíssi- / ma, qual debe ser, según su institución. Este ha sido el ba- / tallón grandísimo en la Yglesia de aora para defender los / doctores cathólicos la definición de Tridentino contra / los potestantes, ia cathólicos novatores, assí que esta santa / Synodo ha dado toda la luz aeste sacramento, según fue / la institución de Jesucristo. Ciño a quatro cánones sub / Anathemate esta feê y su explicación. Los cánones 3, 4, 6 / de la sesión 13 dizen lo que en esto ai ${ }^{107}$, y Vuestra Paternidad puede ver / (que) en ellos se define la potestad de remitir los pecados da- / da a la Yglesia en aquellas palabras: Accipite Spiritum san- / tum, quorum remiseritis peccata, remituntur eis ${ }^{108}$. Las / partes de la confesión espera(n) la íntegra y perfecta re/ misión de los pecados, que son confesión, contrición y / satisfacción. Define que la confesión sacramental es / instituida por derecho divino ${ }^{109}$, como necesaria ad salutem, / y que la Yglesia desde los principios obserbó el modo de / confesar secreto el pecado â solo el sacerdote, y por eso / anatematiza al que dixese que ese modo es ageno de / la institución y mandato de Cristo, y que solamente es in- / vención nueba y humana, como no practicada en / la Yglesia primitiva, y últimamente define que es de derecho / divino el que el pecador confiese: omnia et singula pec- / cata mortalia, por precisión ad salutem obtinendam, $/ /{ }^{17 \mathrm{r}}$ y que no es solamente útil ad erudiendum, et consolandum $p(o)$ $e$ - / nitentem, nique, si se obserbó en algún tiempo esa confe- / sión, fue tantum obserbata ad satisfationem imponendam cano- / nicam ${ }^{110}$. Esta es la summa de la Doctrina Cathólica sobre / el sacramento de la Penitencia.

Sobre este punto han bramado los herejes doctos. / No dexan piedra que no muden, singularmente el Daleo / protestante, para indagar, examinar y repasar todos los / archibos escritos, monumentos antiguos de los tres primeros / siglos de la Yglesia, y comprobar con el uso y el hecho de la prác- / tica antigua que la nueva definición del Tridentino es / falsa y novedad humana, lo que se dize del sacramento / de la Penitencia. Pero los doctores responden suficientemente / a sus cabilaciones, y siempre se ve victoriosa la ver- / dad

${ }^{107}$ El c. 3 trata sobre Jn 20,22 como fundamento de la autoridad eclesial para remitir y retener los pecados (cf. DH 1703), el c. 4 sobre la necesidad de los actos del penitente (cf. DH 1704) y el c. 6 sobre la confesión como instituida y necesaria para la salvación (iure divino) (cf. DH 1706).

108 Jn 20, 22-23.

${ }^{109}$ Véase lo expresado en la introducción sobre las diversas interpretaciones del iure divino.

110 Trento, sesión XIV, c. 7: I. López de Ayala, El sacrosanto y ecuménico... 171-172 (DH 1707). Variante: "Et olim observatam fuisse tantium ad satisfactionem canonicam imponendam". 
definida. Lo cierto es que nunca demuestran estos malsi- / nes ${ }^{111}$ lo negatibo de no haber habido el uso del sacramento. / Es verdad también que ni los cathólicos pueden demostrar / la parte afirmatiba de su uso, del modo que oi se usa en la / Yglesia. Pero siempre salban con verdad sólida la definición / de la Yglesia, aun en su antigüedad primitiva. No lo demu- / estran, porque se oie en lo antiguo la confesión pública / y públicas penitencias. Los quatro órdenes de peni- / tentes conviene asaver, el orden flentium, auditionis, / substractionis et consistentiae ${ }^{I I 2}$. Y si se enquentra algún / pasage en san Agustín, ô en el Chrisóstomo, que diga con / la pentiencia oculta y confesión auricular, fácilmente //17v ola construien de la pública, o infieren el poco o nin- / gún uso, y, de ai, no ser necesaria ad salutem, sino la / Penitencia coram Deo, y no coram Presvitero. Ô / también inferían no ser usso antiguo la confesión / íntegra de todos y de cada uno de los pecados, como de- / finió el Tridentino.

Mucho an trabajado los cathólicos en sacar la / verdad de esa definición, como es cosa de hecho, depende de la Ystoria y sucesos de siglos tan remotos. Con su / mucho estudio de historiales, acasos escritos de los Padres, / exortaciones en los sermones a la pleve y práctica / de los prelados en sus Yglesias, han podido averiguar / muchas cosas que conducen a la definición conciliar, / aside la siempre usada la confesión auricular, su inte- / gridad quoad omnia et singula pec(c)ata, sus partes, su / necesidad ad salutem, ser el sacramento secunda tabula iure / divino post baptismum lapsis in peccatum ${ }^{113}$. Su author Jesu- / cristo, su intención, la práctica misma, que ahora saltem / quoad substantiam ${ }^{114}, a b$ inicio siempre entendida, y ob- / servada desde la primitiba Yglesia.

${ }^{111}$ Del hebreo malsín: cizañero, soplón (https://dle.rae.es/mals\%C3\%ADn).

${ }^{112}$ Conforme al Derecho Eclesiástico de la época, dichos órdenes se describen así. En primer lugar, el orden de los afligidos (ordo flentium), que, postrados en el vestíbulo de la iglesia, imploraban las oraciones de los fieles y que eran admitidos para cumplir la penitencia pública. El segundo se corresponde con el de los oyentes (ordo audientes), es decir, el de aquellos cuyos ruegos habían sido escuchados por la comunidad y se les permitía escuchar, desde la parte última de la Iglesia, la proclamación de la Escritura y el sermón del obispo. El tercer orden era el de los postrados (ordo genuflecdentium o substractorum), que, ya en la nave de la iglesia, recibían las imposiciones de manos y las bendiciones del obispo. Por último, el de los sentados (ordo consistentium), que, aunque todavía no presentaban las ofrendas ni podían participar de la Eucaristía, sin embargo, podían sentarse al final de la iglesia y, con el resto de los fieles, asistir a la oración común (cf. P. J. Riegger, Institutionum iuris prudentiae ecclesiasticae. Pars IV. Libros IV et V. Decretalium Gregorii IX, P., Trattnern, Viennae 1780, 397-398).

113 Trento, sesión XIV, capítulo 5: I. López de Ayala, El sacrosanto y ecuménico... 153 (DH 1679). Variante: "Et omnibus, post Baptismum lapsis, jure divino necessariam existere". Adviértase que, en esta ocasión, el concilio no habla de la penitencia como segunda tabla de la salvación.

${ }^{114}$ Es esta una fórmula antiprotestante, tal como se advierte en Francisco Suárez, Defensio Fidei Catholicae et apostolicae adversus anglicanae fectae errores, Didacum Gomez de Loureyro, Conimbricae 1613, 630. 
Lo primero han hallado que, desde el primer / siglo de la Yglesia hasta el décimo, viguit usus quidam de / Penitencia publica, con la que eran castigados cier- / tos atroces crímenes, ô públicos o denunciados al / obispo. Estos castigos eran separarlos de la Yglesia o pri- / varlos de la Eucaristía, y otros exercicios de Peniten- $/ /{ }^{18 r}$ cia, como aiunos largos y penosos, oraciones y cosas se- / mejantes ${ }^{115}$. Lo $2^{\circ}$, que siempre viguit obligatio de denun- / ciar al obispo a los delinquentes. Lo $3^{\circ}$, que a la pública / penitencia se sujetaban no solo la ydolatría, el homoci- / dio y adulterio, sino también otros mui graves crí- / menes, si eran públicos, o legitime provocados. Lo $4^{\circ}$, que / si los crímenes no eran públicos, sino secretamente / denunciados o manifestados (?) al sacerdote por con- / fesión voluntaria, entonces se dexaban al juicio pru- / dente del sacerdote ô del ôbispo el determinar, atendi- / endo a la condición de la persona y circunstancias, si / se habían de castigar con pública penitencia. Por / esto, común y regularmente se libraban de esta pública / penitencia los clérigos, las casadas, las doncellas, los jó- / venes, y universalmente los que confesaban pecados en los / sagrados penitenciales cánones no comprehendidos, ô pe- / cados no reservados, llamados reservados aquellos a los que / taxata erat per canones Penitencia ${ }^{116}$. Lo $5^{\circ}$, que en el si- / glo sexto se comenzó a seguir la regla de sugetar a la / penitencia pública simpliciter tal de substracción a- / quellos crímenes que en el fuero externo se castiga- / ban con pena de muerte. Lo $6^{\circ}$, que siempre en la Yglesia / avía obligación de confesar qualesquiera pecados reserva- / dos, esto es, los que en los cánones penitenciales se con- / prehendían sub pena, aunque no fuesen públicos ni de-/ nunciados, sino plane ocultos. //18v

Esta práctica antigua descubierta ia se ve que poco / sirve para el asumpto grande de la confesión sacramen- /tal al sacerdote. Por eso han trabajado mucho los / theólogos cathólicos para tapar la boca a los hereges, por / descubrir lo visto: que viguit in Ecclesia siempre la obli- / gación de sugetar a las llaves de la Yglesia omnia peccata / mortalia, aun los no reservados, en orden a darles / penitencia, poniendo a los delinquentes saltem in ordine /

${ }^{115}$ Se refleja aquí la tradición de la primitiva Iglesia, que, en la línea de la tradición judía, practicó un modelo penitencial de excomunión, mas no tanto para apartar definitivamente al penitente, cuanto como llamada de atención que provocara su conversión y su regreso a la comunidad eclesial. La finalidad de la exclusión, por tanto, es doble: salvaguardar la integridad de la Iglesia y favorecer la salvación del pecador. Es así como hoy se comentan textos como 1Cor 5,1-13 (cf. P. Caspani, Lasciatevi riconciliare in Cristo, Cittadella Editrice, Assisi 2013, 21; M. Ponce Cuéllar, Tratado general de los sacramentos, Edicep, Valencia 2005, 260-261) y, sobre todo, la interpetación eclesiológica de Mt 16,17-19 (cf. J. Ramos Regidor, El sacramento de la penitencia... 151-164; A. Maffeis, Penitenza e unzione dei malati, Queriniana, Brescia 2012, 111-135).

${ }^{116}$ Referencia a la penitencia tarifada. 
consistentiam $^{117}$, que eran los que por sus delitos no comul- / gavan apartados de la Eucharistía. Por esto añaden que / en la Yglesia siempre se dio y se conoció la obligación / de confesar congruo tempore saltim ${ }^{118}$ in pericolo mor- / te, omnia prorsus mortalia, aunque oculta ${ }^{119}$. Esta / conclusión en que está el punto la prueban lo primero quando / vemos a los Padres que istan y urgen a los fieles sobre la / confesión que se hace al sacerdote. No hablan de / pecados reservados solamente, sino de todos: instan indis- / criminatim. Lo $2^{\circ}$, la práctica de confesar todos los / pecados sin distinción de unos a otros se ve ia en el $5^{\circ} /$ y $6^{\circ}$ siglo; aquí no se introduxo por nuebo orden ni / mandato, ni por alguna conciliar disposición; luego se / ve que vino de la antigua tradición. Lo $3^{\circ}$, porque ia en / el $4^{\circ}$ y $5^{\circ}$ siglo se ve esa práctica en la Yglesai occi- / dental saltem. Lo $4^{\circ}$, porque vemos ia en los dichos siglos $/ 4^{\circ}$ y $5^{\circ}$ que todos los cristianos querían confesar / integre de todos los pecados saltem in articulo mortis. $/ /{ }^{19 \mathrm{r}}$ Estas antigüedades las prueban con mil testimonios, au- / thoridades y monumentos antiguos; pero, aunque / son pruebas verosímiles, pero no para convencer â / los doctos hereges, que reproducen argumentos â sus / soberbios ôjos indisolubles.

Entre muchos dicen que, si fuese conocida la / penitencia sacramental por necesaria, los Padres la / instaran, la mandaran, la urgieran, y vemos, dicen, que / no instan esa confesión al sacerdote, antes se ve en san / Juan Chrisóstomo que dice no ser necesaria, porque ense- / ña muchas veces que se debe confesar â solo Dios, y que / no es necesario que confesemos homine ac conserbo. / Lo $2^{\circ}$, porque dice que la confesión se ha de hacer sola me- / moria, seu emimeratione omnium peccatorum, para que / assí exubescat de suis pec(c)atis, coram Deo quotidie, sicut / David dicit: Se confiteri pec(c)ata sua Domino; et quia Pro- / feta dicit: Dic, iniquitates tuas ut justificeris ${ }^{120}$. Lo $3^{\circ}$, por- / que, en infinitos lugares en que habla de la Penitencia, en nin- / guno dice claramente que se deben confesar los pecados al / sacerdote, antes señala los medios para que sean perdonados; / conviene asaver: las limosnas, el perdonar las injurias, / el aiuno, la humildad, y si dice de la confesión, no deter- / mina an sacerdoti

${ }^{117}$ Referencia al orden de los consistentes, visto anteriormente.

${ }^{118}$ Variedad de saltem.

${ }^{119}$ Doctrina clásica sobre la integridad de la confesión en la teología sacramentaria del momento, como puede percibirse en Jacobi Platelii, SI, Synopsis cursus theologici, Viduae B. Belleri, Duaci 1706, 584; Honorati Tournely, Cursus theologicus scholastico-dogmaticus, sive Praelectionum theologicarum, IV, Metternichiana, Coloniae 1751, 135; Renati Hyacinti Drouven, De re sacramentaria contra perduelles haereticos. Libri Decem, Tomus Tertius, Thomam Lettinelli, Venetiis 1789, 194, entre otros ejemplos.

${ }^{120}$ La cita profética es Is 43,26. 
sit facienda; solamente recurre â / la penitencia interior y lágrimas: v.gr., en la homilía / sobre el Salmo 50, dice: Si in pec(c)atorum tuorum memoria / venerit collachrisma, atque hac ratione ea in lecto de- $/ /^{19 \mathrm{v}}$ lere potes ${ }^{121}$. Si millies pec(c)asti, millies p(o)eniteas. Haec phar - / maca indesinenter adhibe ${ }^{I 22}$. Estas cosas que se ven en / los Santos Padres y en san Agustín frequentemente no deben mu- / dar un punto la grande idea del sacramento que nos / ha dado la Yglesia por el Spíritu Santo, enseñándonos ia cla- / ramente la intención benigna del Salbador en haber / dado tal medicina para nuestras llagas. La idea de el / sacramento ha sido siempre una, quoad substantiam / en la Yglesia, pero quoad usum disciplinam y de los frutos / prometidos por el sacramento, tiene oy más luz, mexor / práctica y más fuctuosa idea.

\section{Regla IV}

La intención de Cristo en el modo y disposición con que / gusta que se administre el sacramento es la regla a la que / el confesor se debe arreglar para administrarlo con gozo / y sin amargo escrúpulo. ¿Y qué intención es esta, dice / mi Padre Maestro? Porque esta intención, dice el Tridenti- / no, fue entendida ab initio, y que no define cosa nueba, / y que no se practicase en la primitiva Yglesia. Digo que / siempre se entendía la substancia del sacramento, sus / partes, su integridad, su necesidad, el cómo, el tiempo, el / quándo. La disciplina y castigo de los delitos ha tenido mu- / chas variaciones según en la diversidad de circunstan- / cias y de tiempo ha convenido, según la idea que de el / sacramento tenían las Yglesias, sus Prelados, hasta que ia / el Spíritu Santo ha dado plena idea a la Yglesia para su frequen- $/ /^{20 r}$ cia, para su útil práctica, y que sea como un manantial / perenne en la Yglesia adonde se laben toties quoties jus- / tos y pecadores, como con buena voluntad lo reciban, /

${ }^{121}$ Variante de los maurinos: "Si in lecto sis, atque in peccatorum tuorum memoriam venias, lacrymare, atque hac ratione ea in lecto delere potes" (Sancti Joannis Chrysostomi, Opera Omnia. Opera et studio: Monachorum Ordinis Sancti Benedicti e Congregatione S. Mauri. Tomus V, Parisiis 1842, 6, 582).

${ }^{122}$ La versión de los Maurinos reza así: "Peccasti? Poenitentiam age. Millies peccasti? Millies poenitentiam age. Haec pharmaca subinde abhibeo, ac tumorem reprimo" (Sancti Joannis Chrysostomi, Opera Omnia. Opera et studio: Monachorum Ordinis Sancti Benedicti e Congregatione S. Mauri. Tomus V, Parisiis 1842, 3, 578). Por su parte, así lo cita Eusebio Amort: "Peccasti? Poenitentiam age. Millies peccasti? Millies poenitentiam age. Haec pharmaca indesinenter applico, et tumorem comprimo" (Demonstratio critica religionis catholicae, nova, modesta, facilis, Joannem Baptistam Recurti, Venetiis 1744, 208). Nuestro autor mezcla ambas tradiciones y las cita libremente. 
perdonando al humilde no solo usque septies, sed usque / septuagies septies ${ }^{123}$. Lo mismo ha sucedido sobre la prác- / tica de las Yndulgencias, práctica desconocida en la / Yglesia hasta el siglo undécimo, y entonces comenzó con / poquedad y escasez, y ia oi vemos tanta franquicie aun / en indulgencias plenarias, con tanto fruto y prove- / cho del Pueblo Cristiano, aunque no logren por su parte to- / do el tesoro. Pues en verdad que la Yglesia nueba no ideara / abrogarse esa potestad de condonar penas a los delin- / quentes en cosa de tanta substancia, sino viera esa / práctica en la Yglesia antigua saltem quoad substantiam, / como se ve aun desde san Pablo, que remitió al incestuoso de / Corinthio después de las penas que le puso, y después era / mui frequente en la Yglesia el que los obispos dieran in- / dulgencia a los reos, principalmente in Cena Domini, absolbi- / éndolos de la pena que les faltaba. Ahora el modo, la solem- / nidad, la frequencia, la menor penitencia, la idea ia ma- / ior, que ai de esa potestad para dar y enriquecer a los fieles / arrepentidos, y para aiudar aun a los defunctos, es lo nue- / bo y mejor ordenado, como sucede en la práctica de el sacramento / con más fruto y provecho de todos.

Pero como (dice mi Padre Maestro) la Yglesia antigua no tubo / idea del sacramento quod substantiam de su integridad quoad //20v omnia pec(c)ata, y singularmente su necesidad ad justifi- / cationem, quando san Chrisóstomo y otros Padres hablan de / la confesión al sacerdote no como precisa, y lo más que / se rastrea es para la hora de la muerte, y en vida comulga- / ban como justificados con sola la penitencia â Dios, con / aiuno, con limosna, oración, perdonar injurias, según / la divina promesa: Dimit(t)e nobis debita nostra, sicut et nos / dimit(t)imus debitoribus nostris ${ }^{124}$. Dimit(t)e et dimit(t)emini ${ }^{125}$. / Beati misericordes, quoniam et ipsi misericordiam con- / sequentur ${ }^{126}$. Date et dabitur vobis ${ }^{127}$. Candem mensura, qua / mensi fueritis, remetietur vobis ${ }^{128}$. Date elemosinam, / et ecce omnia munda sunt vobis ${ }^{129}$. Petite, et accipietis ${ }^{130}$; y assí / mil promesas sobre la limosna, y el perdón de inju- / rias. En esto se ve que había poca idea del sacramento / en lo antiguo, o lo menos si se juzgaba

${ }^{123}$ Mt 18,22.

${ }^{124}$ Mt 6, 12.

${ }^{125}$ Lc 6,37.

${ }^{126}$ Mt 5, 7.

${ }^{127}$ Lc 6,38.

${ }^{128} \mathrm{Mt} 7,2$. Variante: "In quo enim juicio judicaveritis, judicabimini: et in qua mensura mensi fueritis, remetietur vobis".

${ }^{129}$ Lc 11,41 .

${ }^{130} \mathrm{Jn} 16,24$. 
útil, mas no / necesario iure Divino, como define el Tridentino. Ya- / demás, si por confesión interna el hombre siempre / se justificaba, se sigue que la confesión y absolución sa- / cramental no es primo justificativa, sino tan solamente / necesaria necesitate pr(a)ecepti, cosa que no conbiene con / la doctrina de los theólogos, ni con la propiedad de las / palabras, por las que al sacerdote se le confiere la / potestad de absolber pecados, y aun quizá por esta idea no / se daba el sacramento (quando se daba) con la forma / absoluta remisiva ego te absolbo, sino con la deprecati- / va absolbat te Deus ${ }^{131}$, por la imposición de las manos. //21r

No se aflixa Vuestra Paternidad ni sospeche que el Chrisóstomo ni los / Padres antiguos tuvieron del Sacramento otra idea quoad subs- / tantiam que la que ahora tiene la Yglesia. Estos otros, y doctrina del / Chrisóstomo acerca de la Penitencia interna sin inculcar / ni instar mucho porque los fieles reciban el sacramento, pudo na- / cer de que los Padres eran de opinión, y de la sentencia que / aun oy no está condenada ${ }^{132}$, conviene asaver: que a la con- / fesión sacramental debía siempre preceder contrición / justificatiba, o quizá sentían que no toda contrición justifica- / ba, sino sola la amorosa e intensa. Ô por lo menos (y es mui / verosímil) sentían, y era parecer de su theología, que por qual- / quiera contrición, aunque no fuese inmensa, y la amorosa se / daba la remisión del pecado para un efecto, y no para otro: el gran- / de y perfecto, conviene asaver: se daba la remisión del pecado / quoad reatum infermi, et p(o)enae aeternae, pero no la remisión / per colacionem gratiem santificantis seu adoptionem hominis in / Filium. Ninguna de estas tres sentencias impugna a la fee, / ni a la decisión conciliar. No la primera, porque fue senten- / cia común, y antigüísima, y aun prevalebat hasta el / Tridentino, y defendieron mordicus tropa magna de varones / eminentes, y theólogos máximos, que era necesaria previa / contrición justificativa para el sacramento de la penitencia; / y aun después del Tridentino no faltan grandes theólo- / gos de los que algunos concilios interfuerunt que aun el / día de oy defienden la antigua sentencia en

${ }^{131}$ Interesante asunción, por parte del autor, de la fórmula indicativa (remisiva, dice él) de la penitencia, en la línea del Concilio de Trento, que conservamos aún hoy, y que le "otorga un particular relieve a la acción y ministerio del sacerdote". Durante el primer milenio se optó más bien por las fórmulas deprecativas, con las que se pide a Dios que absuelva y perdone los pecados de quienes imploran su misericordia, de modo que se prima el papel de Cristo como ministro principal del sacramento (cf. D. Fernández, El sacramento de la reconciliación, EDICEP, Madrid 1977, 255). En la revisión del ritual del sacramento tras el Concilio Vaticano II, se debatió proponer diversas fórmulas de absolución, tanto indicativas como deprecativas, para que los sacerdotes o las conferencias episcopales eligieran en cada momento. Sobre la reforma del ritual, cf. A. Gubnini, La reforma de la Liturgia (1948-1975), BAC, Madrid 1999, 577-593.

${ }^{132}$ Interesante referencia a la diversidad de escuelas y a las cuestiones debatidas, mas no definidas. 
toda la anti- / güedad celebrada. Después del Tridentino sensim han- $/ /^{21 v}$ se inclinado maior número de doctores ala sentencia / que dice: basta la atrición ${ }^{133}$ que preceda, la que ha preba- / lecido ala antigua. Y si fue, y es lícito a tantos doctos doctores ense- / ñar que la contrición justificatiba debe preceder al sa- / cramento de la penitencia, que mucho que el Chrisóstomo / la predicara y la urgiera sin oponerse a la doctrina de / la Yglesia, por lo qual se dice que suff(f) icit confes(s)io interna / ad delenda pec(c)ata; pero no basta ad christiano pr(a)ecepta ad / implenda ${ }^{134}$. Ni la segunda opinión es contra la feê, / pues oy la defienden insignes theólogos, que dizen que / sola la contrición intensa y amorosa justifica, y reflexio- / nando los dichos del Chrisóstomo, este parece era su pensa- / miento.

La tercera sentencia es más dificultosa, pero ni / es contraria a la doctrina de la Yglesia, porque no es de feê que / los Padres del Testamento antiguo obtubieron la remisión de los pe- / cados en ambos efectos; ni que se dixieron y fueron justos, ami- / gos e hijos de Dios en el sentido proprio, y por haber recibido / actu la gracia justificante, con la que actu adoptamur in statu / filiorum Dei. Porque una cosa es recibir la remisión de los / pecados por condenación extrínseca, remitiendo Dios el / reato de la pena y su indignación enemiga; y otra cosa es / recibir la remisión de la culpa por infusión de la gra- / cia, y adopción sobrenatural en hijo de Dios ${ }^{135}$. Porque / una cosa es ser el hombre justo por la justicia de su vo- / luntad y rectitud de la mente; y otra cosa es ser //22r justo por gracia santificante e infusión del Spíritu / de Cristo, para ser hijo heredero del reino y hermano / del Unigénito. Finalmente, una cosa es ser hijo y here-/dero con Cristo designatione, seu destinatione; y otra co- / sa es ser ia hijo actuali adoptione, seu actuali investi- / tura per Spiritum San(c)tum, qui datus est nobis ${ }^{136}$. Por esto, el / evangelista san Juan admira la gracia del nuebo Testamento / sobre el antiguo, en el qual los justos eran hijos tantum no- / minati, seu destinati. Pero en el nuebo, quotquot autem / receperunt dedit eis potestatem filios Dei fieri ${ }^{137}$. Videte (dice) / qualem cha-

${ }^{133}$ Véase lo dicho en la introducción sobre las disputas entre contricionistas y atricionistas.

134 Doctrina tomista dominante en la dogmática y moral del momento. Véase E. Amort, Demonstatio critica... 199; Ludovici Habert, Theologia dogmatica et moralis ad usum seminarii catalaunensis, II, Mattaei Rieger, Germania 1751, 260; Celestino Oberndorffer, Theología dogmatico-historico-scholastica ad usum inclyti et episcopalis lycei frisingensis, Sebastiani Moesmer, Frisingae 1777, 236; Antonio de San José, Compendium salmanticense in duos tomos distributum universae theologiae moralis, II, Benedictum Cosculluela, Pomplonae 17915 , 80.

${ }^{135}$ Sobre la diferencia entre pena y culpa, y la cuestión del reato de la pena, recuérdese lo dicho en la introducción.

${ }^{136}$ Cf. Rom 5,5.

${ }^{137}$ Jn 1,12. Variante: "Quotquot autem receperunt eum, dedit eis potestatem filios Dei fieri”. 
ritatem dedit nobis Pater, ut Filii Dei nomine- / mur, et simus ${ }^{138}$. Aora pues, si salba fide ${ }^{I 39}$, es lícito sentir / así de los Padres del viejo testamento, porque no será lícito / al christianismo sentir igualmente de los pecadores convertidos; esto / es, que por la contrición antes de la sucepción del Baptis- / mo, o de la absolución, logren que por sus pecados ia no ca- / igan en la pena eterna de la cárcel infernal tenebrosa. / Pero que ni logren tampoco la herencia de los hijos de Dios, / porque sí pertenecen al Reino por destinación, pero no / por la actualidad de la filiación selecta que recibieran por / la baptismal agua; ô por las de la sacramental peniten- / cia. Por eso quizá el Tridentino con acuerdo, poniendo las / partes y requisitos del sacramento de la penitencia, añade que / se requiere ad integram et perfectam remis(s)ionem pec(c)atorum ${ }^{140} ; \mathrm{y} /$ ia se ve qual es la entera y pefecta remisión de las / culpas, quando no solo nominemur filii Dei; sed vere //22v et actu simus ${ }^{141}$.

Esto es mui verosímil. Pero lo más dificultoso / está en la integridad de la confesión, quoad omnia et singu- / la pec(c)ata. Porque, considerados todos los testimonios de la anti- / güedad, no queda demostrado (desuerte que callen los acható- / licos) que los fieles de la Yglesia primitiva conocieran la obligaci- / ón de confesar toties quoties todos los géneros y especies de pe- / cados, y mucho menos el número que oy se juzga materia nece- / saria y parte esencial del sacramento de la Penitencia. Porque / se ve que muchísimos pecados que oi nos horrorizan, eran ten- / nidos y reputados, y hechados ad peccata minora, quotidiana / et dificulter evitabilia infirmitati humane. Por eso decían / poderse purgar oratione Domenica, sin ser necesario el / sugetarlos a las llaves de la Iglesia como oi se manda. Y aun / quando se ve en los siglos 6, 7, 8, más uso de este sacra- / mento, no se ve que en los penitenciales (enque se ponen todos / los géneros de pecados, que se han de sugetar al ministerio de / los Presviteros) se pongan todos los pecados tenidos por mor- / tales, v. gr., las blasfemias ex ira, imprecaciones malas, perju- / ros non graviter nocibos al próximo, detracciones graves, / injusticias en los contratos, actos de inmisericordia grave, / delectaciones obscenas en el pensamiento y en la vista. Dis- / cursos obscenos, ósculos lascibos, tactos impúdicos. Deseos / pravos de venganza, de concupiscencia. Y las trans- / gresiones del aiuno, del oír misa,

${ }^{138} 1 \mathrm{Jn} 3,1$.

${ }^{139}$ Referencia al primado de la fe protestante.

${ }^{140}$ Trento, sesión XIV, c. 4: I. López de Ayala, El sacrosanto y ecuménico... 171 (DH 1704). Véase Tomás María Cerboni, Institutiones theologicae quoad ad usum scholarum auctore ac magistro divo Thoma Aquinate, Tomus VI: De sacramentis ecclesiae, Ildephonsi Mompié, Valencia 1824, 293.

${ }^{141}$ Referencia implícita a la tesis protestante de la justificación forense. 
descuidos de cumplir los / votos de limosna, castidad, et paupertatis opera non consu- //23r mato. El sacrilegio per indigum communionem: las dudas / contra la feê y las heregías internas, im( $m$ )o las externas / nondum rupta externa unione eum Ecclesia; las gulas in cra- / pula et ebrietate. Estas culpas y otras innumerables fue- / runt rebocata ad pec(c)ata minora quotidiana, et dificulter / evitabilia, yno había obligación a confesarlas, sugetán- / dolas alas llaves de la Yglesia ${ }^{142}$.

Ya querrá mi Padre Maestro saver cómo se / compone esto, con lo que tenemos mandado creer por el Triden- / tino. Norabuena que se conceda este antecedente, por no / terquear en cosa de hecho con los soverbios y doctos presumi- / dos, que juzgan tener toda la práctica e historias antiguas de / los más remotos siglos a sus ojos ${ }^{143}$. Pero de eso nada se sigue / contra el Tridentino, si se quisieran humillar asus decretos; / porque de ese antecedente solo sale este consiguiente: luego / la práctica de este sacramento no es la misma en la Yglesia an- / tigua que en la moderna. Pero se distingue: Non est eadem / praxis quoad speciem infimam confesimis, transeat; quoad ratio- / nem generieam, se niega. Es assí que Cristo no es de feê que / instituiese los sacramentos, determinando las materias en to- / dos quod speciem infimam, v. gr. en la confirmación, en los sagrados / órdenes, en el Matrimonio, en la extremaunción. Aora pues no / sintiera contra la feê del Tridentino el que dixera que Christo dejó / a la Yglesia Potestad para determinar la materia del sacramento / quoad speciem infimam, y por eso Potestad para determinar quán- / tos y quáles pecados quiera reservar a las llaves de la Yglesia ${ }^{144} . / /^{23 v}$ Assí lo siente el célebre autor cathólico del que dize el padre Morino ${ }^{145}$, libro 8 de Penitencia, capítulo

${ }^{142}$ Enumeración de pecados en el mismo sentido en E. Amort, Demonstratio critica ... 253.

${ }^{143}$ Referencia a los protestantes y a su única aceptación de lo reglado en las primitivas iglesias y los primeros concilios, estimando novedoso lo proclamado en el Tridentino.

${ }^{144}$ Interesante alusión a las diversas formas de entender el fundamento cristológico de los sacramentos y, por consiguiente, de interpretar la institución sacramental (cf. B. Forte, La eternidad en el tiempo, Sígueme, Salamanca 2000, 257-264; A. González Dorado, Los sacramentos del evangelio, CELAM, Bogotá 1991, 171-185; J. Granados, Tratado general... 75-104; F. Taborda, Sacramentos, praxis y fiesta, Paulinas, Madrid 1987, 117-125).

${ }^{145}$ Jean Morin, o Johannes Morinus (Blois, 1591-París, 1659), fue un biblista y teólogo francés de gran prestigio, de tendencia galicana, versado en el conocimiento de las lenguas, la Escritura y la tradición eclesial, especialmente de los Santos Padres y de los escolásticos. Hijo de padres calvinistas, se convirtió al catolicismo en 1615 e ingresó tres años más tarde en la Congregación del Oratorio de Nuestro Señor Jesucristo. Conocedor de la tradición oriental, entre 1638 y 1640 fue llamado por Urbano VIII a Roma para integrar una comisión que estudiara los ritos de la Iglesia oriental (cf. L. Hervás y Panduro, Biblioteca jesuítico-española, II, Taravilla, Madrid 2009, 73; J. I. Fortea Pérez, "La asamblea del clero de 1641 y el debate en torno a la contribución eclesiástica en Francia": A. Galán Sánchez y J. M. Nieto Soria (eds.), Poder, fisco y sociedad en las épocas medieval y moder- 
25, número 15, ser author de ninguna / sospecha: este es el padre Hallerio ${ }^{146}$, quien distingue entre la / materia Phísica y la moral de los sacramentos. Y añade / que la Yglesia no ha recibido potestad para las materias Phísicas: / pero que las morales dependen del juicio, y determinación / de la Yglesia. De aquí infiere que (en) el sacramento de la penitencia, ma- / trimonio y orden puede determinar lo que juzgase ser conveniente, y razón.

Esta doctrina del padre Hallerio no repugna ala Escriptura / ni a la feê cristiana, porque Cristo dixo: Quodcumque ligaveritis, erit / ligatum $^{147}$; quorum remiseritis, erunt retenta ${ }^{148}$. Luego Cristo dexó libre / a la Yglesia el reservar a su juicio y llaves los pecados que quisiere. $\mathrm{Ni} /$ repugna al Tridentino, porque aunque en la sesión 13, capítulo 5, declara â Cristo / integram pec(c)atorum confe(s)sionem fuise institutam eamque post Baptismum lapsis, iure / divino

na, Ministerio de Hacienda, Madrid 2018, 309-338; http://www.nuovorinascimento.org/rosp-2000/ persone/morin.htm; http:/www.treccani.it/enciclopedia/jean-morin; https://www.britannica.com/ biography/Jean-Morin-French-theologian). Entre otras obras, publicó un famoso Commentarius Historicus de disciplina in administratione Sacramenti Poenitentiae tredicim primis saeculis in Ecclesia Occidentali et huc usque in orientali, Frederici à Metelen, Antuerpiae 1682 (primera edición en París, en 1651), donde pone de manifiesto su criticismo y su quehacer positivo. Su magisterio sobre el sacramento de la penitencia fue muy valorado por los defensores de las tesis contricionistas, considerando sus estudios erudísimos (cf. Giuseppe Lavani, Lezioni sacre e morali sopra il santo libro degli Atti Apostolici, III, Salomoni, Roma 1781, 11). Sin embargo, era detestado por los atricionistas, tal como se advierte en la argumentación de Giuseppe Benaglio sobre la falta de apoyo en los Santos de la tesis que defiende la necesidad de un amor benevolente para justificarse en el sacramento de la penitencia, ya sea imperfecto, en sentido teológico, o inicial, en el sentido que le otorgaban los que él denominaba 'nuevos' doctores, que tenían como punto de referencia al P. Morino (cf. Conte Giuseppe Benaglio, Dell'Attrizione, quasi materia e parte del Sacramento della Penitenza, secondo la dottrina del Concilio di Trento, I, Claudio Wilmant, Milano 1846, 333-334).

${ }^{146}$ Es presumible que el autor se refiera a Ricardo Haller (1551-1612), jesuita alemán, maestro en filosofía y doctor en teología. Durante bastantes años estuvo encargado de los estudios de la Compañía en diversos colegios y universidades, incluso en el recién creado noviciado de Landsberg. Confesor de la archiduquesa Margarita, vino a la corte española en 1598, donde no contó con la anuencia del duque de Lerma. El general de la Congregación aprovechó su puesto para defender ante la Corona los derechos de la Compañía. De cariz belicista en la política exterior, se caracterizó por su moderación en los postulados teológico-morales, como se advierte por sus aportaciones en las juntas que abordaron la expulsión de los moriscos. Por lo que a nuestro tema se refiere, propagó el acto de la contrición con su Breve apuntamiento acerca de la contrición, según unos en 1580, según otros, ya en el siglo XVII, pues no aparece en la impresión ni lugar ni fecha de la misma. Este opúsculo tuvo gran difusión tanto en Europa como en América Latina (cf. F. B. Medina, "Haller, Richard": C. O’Neil y J. M. Domínguez (dirs.), Diccionario histórico de la Compañia de Jesús, II, UPCo, Madrid 2001, 1871; F. Labrador Arroyo, "Haller, Ricardo": http://dbe.rah.es/biografias/20398/ricardo-haller; A. González Polvillo, Análisis y repertorio... 57-58).

${ }^{147}$ Mt 16,19. Variante: "Quodcumque ligaveris super terram, erit ligatum et in caelis".

${ }^{148}$ Jn 20,23. Variante: "Quorum remiseritis peccata, remittuntur eis: et quorum retinueritis, retenta sunt". 
necesariam existere; Christumque sacerdotes sui vicarios reliquisse / ad quos omnia mortalia crimina deferantur. Et eum hoc juditium / causa incognita a sacerdotibus exercere non posit opportere $\hat{a} / p(o)$ enitentibus omnia mortalia peccata in confe(s)sione recensere ${ }^{149}$. / Aunque el Concilio de Trento, digo, declara esto, pero fácilmente / se responde que todo eso lo pudo y debió decir el Tridentino porque, / quando sermo est de instituir algo, de dar luz, fundar derecho, poner / precepto y obligación, se deben poner las proposiciones absolutas y / puras; porque la intención del legislador siempre respicit pri- / mario ad statum sui objecti perfectum, aquel que ultimato tiene en / su ánimo. Esta es $a b$ initio su intención, aunque no siempre in- $/ /^{24 \mathrm{r}}$ tente llegar desde luego aeste estado perfecto. Lo pretende, pero no / statim succesive, según lo permitiere la condición de los tiempos, / de los lugares, de las personas, de las circunstancias. Por eso, en seme- / jantes instituciones ai lugar ala variación en quanto a la observancia / de las Leies, y asu execución según la prudente determinación / de los Prelados. Yaun las mismas leies tacite son modales, desuerte / que hagan este sentido restricto, no absoluto: Volumus hoc fieri, et ur- / geri, in quantum conditio temporum, locorum, personarum, et circunstan- / tiarum permiserit ${ }^{150}$.

Assí Cristo dice: Multa habeo vobis dicere, sed non potestis / portare modo ${ }^{151}$. Y san Pablo: Non potuit vobis loqui quasi spirituali- / bus, sed quasi carnalibus $^{152}$. Del mismo modo la monogamia, v.gr., / est juris naturalis, et divini, pero tacite fue modal assí: Inquantum / conditio temporum permiserit. Assí también la abrrogación dela / Ley de Moisés en la nueba fue dada per legem abstolutam, y por con- / cilio Apostólico, y miraba al estado perfecto. Pero mientras pudo te- / ner ese estado, la circuncisión fue permitida, y aun la abstinencia / a $\operatorname{su}(f)$ focato et sanguine aliquando ${ }^{153}$ fue mandada, porque entonces / convenía. Del mismo modo, Cristo ordenó otras muchas cosas, saltem / implicite, y las tubo in intencione esplicándola(s) con términos / generales, v. gr., la profesión explícita de todos los artículos que / succesive y con el tiempo se habían de definir en los concilios / generales, el culto e inbocación expresa de los santos, la adora- / ción solemne de Cristo in Eucharistía, el uso de las indulgen- / cias pontificias, la ex-

${ }^{149}$ Se trata de la sesión XIV, y no de la XIII, como indica el autor. Llama la atención este desliz, porque un poco más adelante, como veremos, transcribe literalmente el inicio de este capítulo 5, escribiendo entonces sesión XIV. En esta ocasión, el autor cita con bastante libertad, redactando un párrafo con frases del texto conciliar. Para el texto de este capítulo, cf. I. López de Ayala, El sacrosanto y ecuménico... 153-154 (DH 1679).

\footnotetext{
${ }^{150}$ Véase también Е. АмоRт, Demonstratio critica ... 254.

${ }^{151} \mathrm{Jn} 16,12$.

${ }^{152} 1$ Cor 3,1. Variante: "Non potui".

${ }^{153}$ Cf. Hch 15,19; 21,25.
} 
tensión de la jurisdicción in rebus disciplin(a)e / del Papado en todos los demás obispados, la deboción universal del pue- //24v blo por los defunctos, el culto de Dios solemne en los templos, el / uso de los diezmos, la inmunidad de las personas, de los lugares y / de las cosas eclesiásticas, la división de la potestad eclesiástica clerical en / subdiaconado y órdenes menores. Las quales cosas, aunque se pue- / dan decir ser instituidas por Cristo, y por eso juris divini, / pero en la execución no / fueron intentadas por todo tiempo ni para qualquiera hedad de la Yglesia, / sino fueron instituidas e intentadas en su perfección para la hedad / de su estado perfecto. Del mismo modo, aunque la Yglesia siempre / aia entendido la integridad de la confesión aver sido intenta- / da por Cristo, y por eso ser juris divini, como dice el Concilio, no / obstante, pudo esa intención e institución de la entera confesión / undequaque haber sido tacite modal, esto es: que obligue certe pro / semper, pero inquantum tulerit conditio personarum, locorum, cir- / cunstantiarum. Por esto, se puede responder que la Yglesia antigua no / juzgó conveniente reservar asu conocimiento todos los pecados como ma- / teria de el sacramento de la penitencia. Además que no está en el / Tridentino definido como artículo de feê que la Yglesia siempre juzgó / y sintió que actu se requiere la confesión entera de los pecados, y que / esto estubo siempre en usso. Porque solamente está definido, y es de / feê, que la confesión íntegra se requiere por derecho divino. Esto se verifica / tácitamente diciendo de Cristo specialiter confirió a la Yglesia jus retinendi / que libet pec(c)ata, asu juicio y conocimiento, ita ut nec Deus ipse velit ea / remi(t)tere, sine confe(s)sione illa peccatorum, que Ecclesia voluerit, pero / congruitate temporum, et locorum retinere, ac su(a) e congnitioni reservare ${ }^{154}$. / De aquí se infieren dos cosas: la una, que no está definido cono artículo $/ / 25 \mathrm{r}$ de feê en el Tridentino que la práctica de la integridad de la con- / fesión, en quanto al número y especie de todos los pecados, semper vi- / guerit, y la otra, que como aboslute necesaria fue en todo tiempo co- / nocida en la Yglesia, porque, aunque parece que el Concilio quiere decir / eso en la sesión 14, capítulo 5 por estas palabras: Ex institutione sacra- / menti P(o)enitentiem tam explicata universa Ecclesia semper / intellexit institutam etiam esse a Domino integram pe(c)catorum confe(s)sionem, / et omnibus post baptismum lapsis, jure divino nece(s)sariam existere: / quia Christus accensurus in c(a) elum, sacerdotes sui ipsius vicarios reli- / quit, tamquam Pr(a)esides, et judices, ad quos omnia peccata mortalia / deferrentur ${ }^{155}$. Y aunque dixo esto, pero no queriendo definirlo todo, sino / loque ciñó y definió en algún canon expreso.

${ }^{154}$ Véase Matthia Dannenmayr, Historiae Ecclesiasticae, Institutiones historiae ecclesiasticae (Panormi, Francisci Arrate, 1815), 241, quien cita a Morin, Haller y Amort, además del Tridentino.

${ }^{155}$ I. López de Ayala, El sacrosanto y ecuménico... 153 (DH 1679). Variante: "E terris ascensurus ad caelos... omnia mortalia crimina deferantur". 
Es assí que no se juzga definido lo que el concilio enseña / en los capítulos, ni se juzga como artículo de feê, ni decisión con- / ciliar, como lo enseña Tournelio ${ }^{156}$, enemigo de los jansenistas in- / tensísimo, mui alabado en Roma por su Tratado de Eucharistía, y / theólogo celebérrimo de la Francia: este, en la questión 4, artículo 6, que / res, dice assí: Illud solum tanquam de fide definitum haberi debet, quod / in Canonibus Conciliorum sub anathematis pena ad credendum / propositum. (...) Namque ea tantum pro definitis de Fide a Tridentino ha- / benda sunt, quae sunt canonibus expres(s)a, et sancita, non quae / in capitulis pr(a)emit(t)untur ad canonum inteligentiam et provationem ${ }^{157}$. / Assí Tournelio. Lo que sí es verdad, más verdad será en las questio- / nes de facto, qual es esta acerca de la constante práctica de la Yglesia, / y más quando sin ella subsisten en su vigor las definiciones conciliares. / Estas están en los quatro cánones de lo que ia dixe. Estos quatro cá- //25v nones son verdaderos, aunque no aia sido siempre usada en la / Yglesia la confesión pec(c) atorum integra.

Lo $1^{\circ}$, porque la Yglesia (aun sin ese uso) siempre en- / tendió las palabras de Cristo: Quorum remiseritis pec(c)ata re- / tenta sunt ${ }^{158}$, de la potestad de re-

${ }^{156}$ Honorato Tournely (1658/9-1729), tras cursar filosofía en París, se doctoró en 1686 y obtuvo la cátedra de Teología, siendo catedrático de la Sorbona entre 1692 y 1716 . Especialista en teología moral, algunos autores lo tachan de jansenista (filojansenista lo cataloga J. I. Saranyana (dir.), Teología en América Latina, II/1, Iberoamericana-Vervuert, Madrid 2005, 661), si bien la crítica más ecuánime lo presenta como un renovador de los temas teológicos desde las nuevas perspectivas de la teología histórica y como un gran conocedor de la teología clásica, cuya doctrina desprende pureza y seguridad (cf. J. Belda Plans, Historia de la Teología, Palabra, Madrid $2010,211)$. De hecho, el autor de esta carta lo presenta como un "enemigo intensísimo del jansenismo", tal como defiende la crítica hodierna (cf. I. Alva Rodríguez, "Francisco Javier Alegre (1729-1788). Una aproximación a su obra teológica": Anuario de estudios americanos 68/1 (2011) 308). Escribió un Cursus Theologici sive Praelectionum Theologicarum, publicado en 1710 (cf. J. J. Leonardo Lemos Montanet, Obra viva, de Ángel Amor Ruibal, Betanzos 2004, 73). De 1725 a 1729 publicó otro curso de teología que lo hizo famoso, al tiempo que lo situó en el ojo de la crítica: las Praelectiones theologicae de gratia Christi, quas in scholis sorbonnicis habuit Honoratus Tournely. En esta obra trata la cuestión de la gracia, intentando equilibrar la gracia eficaz y la eficiente. Por lo que a nuestro tema respecta, resulta intereante su Carta de un theólogo de Padua, escrita a otro joven de Bolonia, en la qual le da alguna noticia de Tournely, y de sus tratados teológicos, vertida del italiano en Español, del 7 de marzo de 1772, en línea, https://books.google.es/books?id=Zh87tuUBJYcC\&pg $=$ PA2\&lpg $=$ PA2\&dq=honorato+tournely\&source=bl\&ots=t3bxvsY7Xq\&sig=ACfU3U3oDrbyyUJe5iA9sbl6DDO4QeTTFA\&hl=es\&sa=X\&ved=2ahUKEwjduLzo7JfpAhWmA2MBHU0PD94Q6AEwA3oECAkQAQ\#v=onepage\&q=honorato $\% 20$ tournely\&f=false.

${ }^{157}$ Honoratus Tournely, Praelectiones theologicae de Augustissimo eucharistiae sacramento, Nicolaum Pezzana, Venetiis 1731, 194. Variante: "In capitibus... ad Canonum subsequentium intelligentiam et probationem".

${ }^{158}$ Jn 20,23. 
mitir los pecados reserbados â / su conocimiento y juicio, y de los pecados $u l$ tro confesos. Lo $/ 2^{\circ}$, es verdad que siempre estubo en uso el modo de confesar se- / crete pec(c)ata reservata Ecclesi(a)e cognitioni, como aora lo es, aunque / non omnia prorsus fuissent reserbata. Lo $3^{\circ}$, es verdad que / la confesión es instituida y necesaria jure divino; porque Cristo, / confiriendo la potestad de retener los pecados, por lo mismo insti- / tuió que esta potestad había de reducirse â usso, y poreso, que vel / aliqua vel omnia pec(c) ata pro congruitate temporum esse reti- / nenda, ac reservanda cognitioni ecclesiae ${ }^{159}$; desuerte que no hu- / biese otro camino, ni para con Dios la remisión se pudiese conseguir / sin el propósito confitendi. Lo $4^{\circ}$, porque sin ese usso siempre es / verdad que ad integram et perfectam remisionem pecatorum se requi- / ere confesión, contrición y satisfacción; porque ia muchos siglos / antes del Tridentino comenzó gradatim el uso de reserbar la / Yglesia asu conocimiento y juicio todos los pecados. Pues ¿porqué no podrá / el Concilio definir esa necesidad de la confesión, precediendo ia la / retención de la Yglesia de todos los pecados? Porque basta para que sea necesa- / ria ala justificación el que alguna cosa sea mandada por la Yglesia. Assí / se ve que el Concilio anathemate fecit a los que negasen que se requi- / ere ad justitiam retinendam vel reparandam observar loque so- / lamente requiere Ecclesiae ordinatione, v. gr. en la sesión 7, canon //26r 13 dize: Si quis dixerit, in Eucharistiae sacramento, non ese / festiva peculiari celebritate venerandum; neque in proce(s)sioni- / bus, solemniter circumducendum, anathema sit ${ }^{160}$. Y en la sesión / 24, canon 9, clericos y sacris ordinibus constitutos pos(s)e Ma- / trinonium validum contrahere, non obstante lege Eccclesiastica, / anathema sit $^{161}$. De adonde se ve que, si estos y otros cánones / se entienden de la obligación fundada indispositione Ecclesiae, / del mismo modo se podrá entender el canon de la necesidad de / la confesión entera, presupuesta la retención de la Yglesia tan an- / tigua quoad omnia pec(c)ata.

Lo $5^{\circ}$, que aun sin esa práctica es verdadero que la entera con- / fesión omnium pec(c)atorum, dequalquiera manera que la Yglesai eam requirit, / la

${ }^{159}$ E. Amort, Demonstatio critica ... 255.

${ }^{160}$ Una vez más yerra el autor en su citación, ya que se trata del c. 6 de la sesión XIII, que dice así: "Si quis dixerit, in sancto Eucharistiae sacramento Christum, unigenitum Dei Filium, non esse cultu latriae, etiam externo, adorandum; atque ideo nec festiva peculiari celebritate venerandum; neque in processionibus, secundum laudabilem, et universalem Ecclesiae Sanctae ritum, et consuetudinem, solemniter circumgestandum, vel non publice, ut adoretur, popolo proponendum, et eius adoratores esse idololatras; anathema sit" (I. López de Ayala, El sacrosanto y ecuménico ... 132; DH 1656).

${ }^{161}$ Variante: "Si quis dixerit, clericos in sacris ordinibus constitutos, vel regulares castitatem solemniter professos, posse Matrimonium contrahere, contractumque validum esse, non obstante lege Ecclesiastica, vel voto...” (I. López de Ayala, El sacrosanto y ecuménico... 297; DH 1809). 
manda como necesaria jure divino. De esto ai muchos exemplos, / v.gr., de derecho divino se dice ser la residencia de los obispos, la obliga- / ción de predicar, obligación de ofrecer sacrificio por el pueblo, la in- / munidad ecclesiástica, la obligación de pagar diezmos, la potestad de / poner entredicho, la potestad pontificia de reservar casos, poner / censuras, recibir apelaciones en causas de particulares legos, de / establecer impedimentos, de exigir ad natas dispensar indul- / gencias universales del thesoro de la Yglesai por vibos y defunctos, la / prohibición de comprobar y vender beneficios, el aiuno quadrage- / simal, la communión eucharística, la observancia del domingo, / la prohibición de las usuras todas, monogamia in veteri testamento, / la observancia de los votos. Todas estas cosas, y otras muchas, aunque / quoad substantiam et quoad obligationem in actu secundo, dependen de la de- / terminación de la Yglesia, no tanquam per modum primo obligantis, sino per $/ / 26 \mathrm{v}$ modum conditionis et ap (p)licationis de la ley aliunde pr(a)eesistentis al / uso actual de su obserbación ${ }^{162}$; assí del mismo modo pudo suceder / acerca de la confesión omnímoda de los pecados mortales: pu- / do suceder, digo, que la Yglesia ab initio no quisiera obligar aun / Pueblo recientemente convertido de la gentilidad al Cristianismo, y / mesclado con gentiles e idólatras (a los que fácilmente volbieran / si los estrecharan) aque confesasen omnia pec(c) ata, que fácilmente / cometían et dificulter erant evitabilia a sus costumbres antiguas, / y feê flaca, contentándose con la obligación de confesar ciertos pe/ cados enormes, quales juzgaban la apostasía, homicidio, adul- / terio y otros semejantes, según el juicio de los Prelados en sus Ygle- / sias y prefecturas.

Ni obsta el que el Tridentino diga en la sesión 14 y defina / (el) canon 1 que el sacramento de la penitencia fue instituido por Cristo, y que / el canon 4 defina que, para la remisión de los pecados, se requiere confesión, / contrición y satisfacción, como partes del Sacramento. Porque, / como dice Bellarmino ${ }^{163}$

${ }^{162}$ Cf. E. Amort, Demonstratio critica... 255.

${ }^{163}$ De familia acomodada y sobrino del papa Marcelo II, Roberto Belarmino (1542-1621) estudió con los jesuitas, en cuya congregación ingresó en 1560. Desde muy pronto sobresalió por sus aptitudes para el estudio, formándose en filosofía en el Colegio Romano e instruyéndose en teología en la Universidad de Padua. En 1569 lo envían a la de Lovaina, donde entra en contacto directo con las doctrinas protestantes y donde destaca como teólogo polemista, rebatiendo las tesis del rector Miguel Bayo. Tras siete años en Flandes, es requerido a Roma, donde regenta la cátedra de Controversias en el Colegio Romano. Fruto de sus lecciones es quizá su obra más significativa: Disputationes de controversiis christianae fidei adversus huius temporis haereticos (1586-1593). Prototipo de la teología contrarreformista, en estos cuatro volúmenes lleva a cabo una defensa, contra los protestantes, de la Iglesia, su constitución, el Papado y su doctrina. Su quehacer teológico se caracteriza por su sólida fundamentación en la Escritura, los Padres, la tradición teológica y el concilio de Trento, así como por la suavidad con la que trata los argumentos contrarios, mostrando en todo momento su querencia de la verdad y del diálogo. Como teólogo del Papa, tras una breve experiencia de gobierno (rector 
De P(o)enitentia, libro 1, capítulo 11, la penitencia fuera sa- / cramento, aunque la confesión no se requiriese jure divino, porque / salbaretur, dice, la razón del sacramento en la absolución ultro / confitentium aut digni p(o)enitentium. Assí no fuera contra el Tri- / dentino el que dixera que la confesión es (nota buena) parte integral / del sacramento, la que se requiera sane assí para la naturaleza del / acto que es judicial, y para su decente administración, como por ser / esa la intención de Cristo, y determinación de la Yglesia. Pero que no / es parte esencial tam ex natura actus, quam ex institutione Christi / pro mello statu Ecclesiae aut conditione personarum dispensabilem. $/ /^{27 \mathrm{r}}$ Ciertamente si oi vemos que varios casos y motivos dispensan de la / antigüedad de la confesión, que experimentamos cada día, / ¿porqué, pregunto, no pudo suceder en los primeros siglos un / complexo de muchas dificultades, y espinas, que se encontra- / ban en la obligación general a la exacta y omnímoda confesión / de los pecados? ¿Y que esto obligó a la Yglesia auna disposición ge- / neral de confesar pe(c)cata, quotidiana, et si gravia? ${ }^{164}$. Y que durase / hasta que viniese otro estado de la Yglesai más perfecto, quando / ia in actu secundum se pudiera perfecte, et ommimode urgere et im- / plere intentio Christi, como está oy.

Esto está dicho ami Padre Maestro para que, viendo la intención / de Cristo en el usso, no sele estreche ni escrupulice en administrar / un sacramento de tanta utilidad y gracia para el creiente franque- / ando ese tesoro, arreglándose ala intención de Cristo, que fue favorecer a los francos dándoles segunda tabla conque salgan del naufragio al puerto.

\section{Regla V}

Según está oi la práctica del sacramento de la Penitencia, / es preciso que esté expuesto aque lo reciban y se les adminis- / tren a los que no lo merecen, pero sin culpa del ministro, que / lo administra con charidad sincera. Esto es

del Colegio Romano primero y provincial de Nápoles después), escribió Christianae doctrinae explicatio (1598), un catecismo al uso para divulgar las doctrinas católicas. Se vio involucrado en la reforma del calendario y en la revisión del martirologio, el texto de la Vulgata, el Ritual romano y el Breviario, así como en la defensa del catolicismo ante los hugonotes, en el caso Galileo y en la disputa De auxiliis. Fue nombrado cardenal (1599) y arzobispo de Capua (1602), cargo, este último, al que renunció. Cf. G. Galeota, "Belarmino, Roberto”: C. O’Neil y J. M. Domínguez (dirs.), Diccionario histórico de la Compañia de Jesús, I (Madrid, UPCo, 2001), 387-390.

${ }^{164}$ Sobre la gradualidad del pecado en la época, cf. E. Amort, Demonstratio critica ... 211, 219; actualmente, cf. CTI, "La reconciliación y la penitencia": http://www.vatican.va/roman_curia/congregations/cfaith/cti_documents/rc_cti_1982_riconciliazione-penitenza_sp.html\#Pecado_-_Pecado_grave_-_Pecados_cotidianos; G. Mora, La vida cristiana. Teología moral fundamental (Santander, Sal Terrae, 2007), 332-346; A. Gesché, Dios para pensar, I (Salamanca, Sígueme, 1995), 80-85. 
preciso, mas no / tanto como me dize el Padre Maestro, quien, ofuscado con los ma- / les que oie, me añade que, atendiendo al moral para absolver, o negar / la absolución, y más atendiendo alas proposiciones conde- / nadas. De veinte personas que uno confiese en un día, / ¿apenas hallará una aquien absolber, pater mi, modice $/{ }^{27 v}$ fidei, quare dubitasti? ${ }^{165}$ Pues io lo mismo de otra manera, porque / de 50, y a veces de 60 y 70 personas que frequentemente / absuelbo en una mañana, apenas hallo de quien dude que / absuelbo como combiene, miro al sacramento con más feê, y / que es institución de un Dios omnipotente, y que es el Spíritu Santo / el que ha ordenado este uso, y frequencia de recibirlo. Y no / creo que será para ningún fruto, ni para perder el tiempo, ni / para que se canse el ministro, y en valde, y que tenga escrúpulo, y / tema el castigo de su charitativo trabajo. Creo sus prome- / sas, y que no con engaño dixo: quorum remiseritis pec(c)ata, remi- / t(t)untur eis ${ }^{166}$. De aquí me parece mi boca quando absuelbo con la / invocación del nombre de Dios, del Padre, ex quo omnia, / del Hijo per quem omnia, y del Espíritu Santo in quo omnia ${ }^{167}$, I me parece una fuente de aguas vivas, que manan de / la cruz del Hijo de Dios, y que salen de mis labios como por / un caño que derrama el agua en los que piden con buena / voluntad, y cae como en ciertas vasijas, ô vasos, los que / la reciben con más o menos fruto, y según es el vaso grande / ô pequeño, estrecho o dilatado, pero siempre con algún pro- / vecho como vengan con buena feê y voluntad a pedir el agua / viba, como la pidió la samaritana ${ }^{168}$.

No obstante, es preciso que para el agua como stetit oleum / por falta de vasija en la viuda de Eliseo ${ }^{169}$. Quiero decir que se / frustre el bien en los que vienen con mala voluntad, o vienen / no solo con pecados (que eso no fuera el daño, pues buscan / en la fuente el remedio), sino que vienen pecando. Estos $/ / 28 \mathrm{r}$ no reciben agua sacramental, pero sin culpa del confesor; / porque este es buen caño que mana la doctrina que apren- / dió sine fictione, et sine invidia communicat etiam misero / pec(c)atori ${ }^{170}$. Más escrúpulo deve tener el ministro sino fuera / fiel caño, si pusiera estorbo al agua para que saliera dulce, pací/ fica y abundante, por estrecharse, limitarse, atascar con es- / torbos el venero, y de aí, que saliera el agua o ninguna, ô arras- / trada como en vena mal rota, la sangre en sangría mal / hecha. Padre mío, si angustiantur vasa carnis, di-

\footnotetext{
${ }^{165}$ Mt 14,31.

${ }^{166}$ Jn 20,23.

${ }^{167}$ Cf. Rom 11,36; 1 Cor 8,6.

${ }^{168} \mathrm{Cf}$. Jn 4,1-42.

${ }^{169}$ Cf. $2 \operatorname{Re} 4,6$.

${ }^{170} \mathrm{Cf}$. Sab 7,13.
} 
latentur / spatia charitatis ${ }^{171}$, y con eso, si fuese sin fruto el sacramento, / que sea la culpa del terco, del perdido, del incrédulo, y no / sea del ministro, ni que quede con escrúpulos por males / agenos. Estos males son precisos en tan infinitos que / vienen al sacramento. La Yglesia es pública escuela de en- / señanza, y hospital de medicina, la fundó el Salbador co- / mo quiso y convino, sin pedirnos consejo. La Yglesia recibe en / su gremio a todos los que creen, y piden, y se baptizan. Es red / ex omni genere piscium congregata ${ }^{172}$. Es era en que está el tri- / go con la paja, y esta es tan abundante que cubre al trigo, y ala / vista parece que se perdió la cosecha siendo copiosísima. Es ofi- / cina figuli adonde ai vasa in honorem et vasa in contumeliam / formata ${ }^{173}$; están los réprobos mesclados con los electos; es / campo donde el buen grano se ve cubierto cizanorum copia et / abundantia ${ }^{174}$. No senos permite hacer división, ni haun pode- / mos segregar con cierto juicio sufriendo la Yglesia a los malos, ha- / ciendo quanto puede para que sean buenos, sin separarlos usque admesem $/ / 28 v$ en que el Juez supremo los separe. No tiene conqué hacerlos / buenos la Yglesia sino es con la doctrina (si la creen, y reciben) y con / los sacramentos y con el castigo. De este poco o nada, sino es en / los males públicos, los que se castigan con otro fuero para correpción / de los impíos; pero con el fuero de la conciencia poco o nada se / puede, con el castigo en un Tribunal de misericordia la que castiga / con mano blanda solamente lo que basta para la enmienda, y siempre / para el bien del que lo desea y pide con buena voluntad.

No viniendo, pues, todos con buena y verdadera voluntad, / es preciso que se dé a veces al indigno, y más siendo infinito el Pue- / blo cristiano, y con mandato estrecho, cuia transgresión tiene vigo- / roso castigo de confesar los pecados mortales cada año por la / quaresma ${ }^{175}$. Además, el mandato de confesar siempre que aian / de tomar la communión; y se recibe muchas veces al año. / Assí mismo la deboción al sacramento es mucha, y ia se tiene en tal / respecto y esperanza de su fruto, que se frequenta aun diariamente / sin mandato, juzgando gran crimen muchos justos el comul- / gar sin sacramental confesión. Esto haze que, por la multitud / y por la frequencia, es preciso que

${ }^{171}$ Agustín de Hipona, s. 69, 1, PL 38, 440-441.

${ }^{172}$ Mt 13,47. Variante: "Congreganti”.

${ }^{173}$ Rom 9,21. Variante: “An non habet potestatem figulus luti luti ex eadem massa facere aliud quidem vasa in honorem, aliud vero in contumeliam?".

${ }^{174}$ Cf. Mt 13,24-30.

${ }^{175}$ Cf. Concilio de Trento, sesión XIV, capítulo 5 y c. 8: I. López de Ayala, El sacrosanto y ecuménico... 157, 172 (DH 1683; 1708). Repárese en el carácter pedagógico de este precepto conciliar, que el autor subraya en varios lugares y que es recogido por la tradición en la conveniencia de la confesión frecuente, como se vio en la introducción. 
muchas veces el sacramento se / frustre, no estando nunca lo bueno y precioso entre muchísimos, / ni aun entre muchos. Esto es assí, pero el confesor ¿porqué se / ha de afligir haciendo su deber? ¿Porqué ha de sacar escrúpulo de / aiudar al Pueblo cristiano, aque cumpla lo que la Yglesia y Dios le / manda, habiendo instituido ese uso el Spíritu Santo. /

Mire Vuestra Paternidad aquántos peligros está expuesto el sacramento / del altar, recibiendo indignos, incrédulos y sacrílegos, y el //29r sacerdote que lo ministra no se aflige, ni escrupuliza, aunque dé / la comunión â centenares de gentes, y aún queda su deboción / más cumplida y ferborosa quando la multitud quam pavit pane / c(a)elestis ${ }^{176}$ es más copiosa y estensa. Dirá mi Padre que tiene el consuelo / de que ia han confesado, y que han pasado por ese crisol, y ael no le to- / ca más. Poco consuelo es ese para no ver el sacerdote en el peligro aque / expone el sacramento poniendo en las lenguas inmundas de muchos / como en un muladar asqueroso con tantas culpas como Vuestra Paternidad me / quenta, y se horroriza, siendo la lengua la que más peca con mil / desórdenes: Quatenus lingua universitas est iniquitatis ${ }^{177}$. Añada / mi Padre el que muchos no confiesan, y, no obstante, comulgan por / cumplir, temiendo el confesor: ô porque se avergüenzan, ô porque / no les riñan, y afrenten, ô porque no los quisieron alguna vez absolber, / y toman la comunión sin confesar. Otros no por esto, sino por / ignorar qué cosa es no quererlos absolber, aunque el confesor les nie- / gue la absolución, y les explique su indignidad, juzgando que ia / cumplieron con esto que dicen toca confesar; con solo el haber con- / fesado, aun sin haber sido absueltos, se ban al comulgatorio sin / escrúpulo, como que no ai más que hazer que lo que hicieron, y ia / van contentos conque confesaron, y comulgaron. Vuestra Paternidad mismo, / con veinte que confesó, dize que apenas uno creê que ba bien absuel- / to, y si los absuelbe, queda con amargo escrúpulo. Pero, si luego / da la comunión a los mismos, de esto no tiene escrúpulo, aun / sabiendo que expone el sacramento del altar (más augusto que / el de la confesión), atantos peligros y desacatos. Y ¿porqué esto? Por / que se save que el sacramento es público, y todos son convidados como en $/ /^{29 v}$ la parábola de la cena, malos et bonos ${ }^{178}$. Él que lo instituió lo dispuso / assí, y supo y previó las irreverencias aque se exponía. El mismo / está allí como Juez secreto, que secretamente haze la distinción, y se- / grega unos de otros, dando a los malos ut juditium sibi ipsis man- / ducent ${ }^{179}$. Pero no quiere

${ }^{176}$ Cf. $1 \operatorname{Re} 18,4$.

${ }^{177}$ St 3,6. Variante: "Et lingua ignis est, universitas iniquitatis".

${ }^{178}$ Mt 22,10.

${ }^{179} \mathrm{Cf}$. Jn 6,55.57. “... poenitentia gravior atque luctuosior, in qua proprie vocantur in Ecclesia paenitentes, remoti etiam a sacramento altaris participandi, ne accipiendo indigne, judicium sibi 
que el ministro segregue publice en acto / general y común. Assí, el Salvador mismo desechó â Judas de la / mesa, pero secrete lo entregó a Satanás et post bucellam introi- / vit in eo diabolus ${ }^{180}$. Este es el consuelo que tiene Vuestra Paternidad en dar la / communión, aunque la expone a mil peligros contra la reveren- / cia de tal sacramento el ver que no le toca más, y hacerlo que debe / un ministro público executor de los órdenes del Salbador, se- / gún este quiso poner esa mesa franca en la Yglesia.

Esto es verdad. Pero io añado a Vuestra Paternidad que, siendo preciso / (por lo mismo) el que el sacramento de la penitencia se exponga a mu- / chos peligros, los que el confesor ni le toca, ni puede escusar- / los, no deverá afligirse, ni excrupulizar en administrarlo â / los fieles, quando la franquea prudenter et juste. Lo mismo sucede / en la confirmación, en el santo óleo, en el matrimonio y en los / órdenes. Enestos sacramentos, como no hay mandato de confesar, / aunque sí lo ai de estar en gracia y de recibirlos con segura con- / ciencia, poco o nada se cuida por el ministro el que se confiese an- / tes el que los recibe. El obispo confirmará centenares con gran / consuelo y sin escrúpulo, aunque puede saber y sospechar la indi- / gnidad de muchos, grandes y chicos, y mozuelos viciososo que se / llegan sin haber confesado, conque expone a irreverencia un / sacramento tan grande, como que es apéndice del Baptismo, y que //30r solo lo pueden dar los prelados, y no los presvíteros. Y porque el obispo / queda consolado y sin escrúpulo de haber confirmado a muchísimos, / y con más y maior complacencia quando es mucha la multitud, y la turba / copiosísima. Porque solamente cuida de lo que le toca, y de hacer bien he- / cho su oficio, y cumplir bien su ministerio repartiendo a todos / los suios la gracia que depositó en el Spíritu Santo. En lo demás que / toca a los confirmandos, ipsi videant. Basta que estén contritos, aun- / que no confesados, y si ellos no procuran la contrición / ni se valen de la confesión, y por eso van mal a la confirmación, / ese mal, esa irreverencia, es mal ageno, el que sibi imputent, y no es mal / del ministro público, que no le toca entonces segregar lo bueno de / lo malo. Assí sucede en los órdenes, en las que, si confiesan, es porque / comulgan; pero las órdenes pr(a)esertim las menores, se dan sin exa/ minar si el ordenado se confesó o no, ipse videat, y si las recibe / indigne, sibi imputet. El óleo se da con gran consuelo de haber / llegado a tiempo el sacerdote al moribundo sin haber recibido / ningún sacramento. El párroco casa sin cuidado maior de que / los contraientes confiesen con solo ver el mandamiento de desposo- / rio. En lo demás, basta que estén contritos y, si no lo están, ipsi vi- / deant, y de los males que de aí nacen, sibi imputent.

manducent et bibant" (Agustín DE HiPONA, s. 352,3,8, PL 39, 1558).

${ }^{180}$ Jn 13,27. 
Esto lo está viendo Vuestra Paternidad y no se atreverá con reglas de el mo/ ral, ni con el Tridentino, a hacer cargo â ningún párrocho, ni / obispo, metiéndolos en escrúpulo sobre que no administran fideliter / el sacramento quando se arreglan en todo a los sagrados cánones, y / concilios, y aquí entra aora mi admiración con Vuestra Paternidad, quien queda con es- / crúpulo amargo, no sea que le falte a la reverencia del sacramento de la $/ /^{30 v}$ penitencia, quando, si falta, es por culpa agena. Más consuelo, / digo, puede tener el confesor en tu ministerio que aun el obispo / y presvítero en otros sacramentos. Porque en la confirmación, v. gr., / ai certeza el que no han confesado, y duda fundadísima y sos- / pecha prudente en muchos de que no van ni contritos. Pero / en la penitencia se sabe fixamente que han confesado. Se ven señas / (provables a lo menos) de su arrepentimiento. Lo piden, lo dese- / an, seles exorta ala perseverancia. Lleban más para la absolución / y exceden los confesados para ser absueltos a los confirmados, en / que el confesor los ha enseñado, reprehendido, les ha predicado / y les ha dado motibos para la contrición con inmediación â / las llagas que descubren, venciéndose en manifestarse. Están / con el empacho y reprehensión más humildes, y por eso más / dispuestos a la absolución sacramental, que no los otros para la / confirmación; yno obstante, el ministro de esta queda sin es- / crúpulo, y con consuelo en confirmar muchos. Y Vuestra Paternidad queda / escrupuloso en absolver en una larga mañana a 4 personas.

Ya oio a Vuestra Paternidad responder que es mucha la diferencia de / este sacramento â los otros de vibos. Porque en estos el ministro lo / comunica y reparte per modum / difusionis et liberalitatis divinam gratiam et misericordiam. Pero en el de la penitencia se da per modum / juditium, y aquí entra mi amargura, dice mi Padre, por escrupu- / lizar si en esta judicatura hago lo que me toca. El obispo, el / presvítero, el que da la communión, hacen lo que les toca, y con / esa certeza quedan con alegría y consuelo de aver ministrado / fideliter en su oficio. Esto es verdad, y no niego a Vuestra Paternidad la razón $/ /{ }^{1 \mathrm{lr}}$ que el sacramento de la pentiencia es, y se da, per modum juditium et sen- / tentiam juditialis, y que se requiere más interiorizarse en la / causa y en la conciencia, que no en otros sacramentos cuios / actos son diversos. Pero no le toca tanto al ministro que pueda darle / escrúpulo amargo sobre si la absolución es irreverencia al sa- / cramento. Porque sobre este punto son iguales todos los sacramentos. / Porque qualquiera ministro que sea fiel administrador de las rique- / zas, que le han entregado para que las dispense con utilidad, / y para el fin aque Dios mira en su institución, debe guardar / justicia entre ambas cosas, entre el sacramento y el hombre / que le recibe. De suerte que al próximo no sele defraude el fru- / to del sacramento, ni a este del honor y respeto debido; y assí / como en todos los sacramentos ai laprecisión por lo dicho ia de que / se exponga a peligro de conferirse â indignos, lo mismo su- / cede en el de la 
penitencia, en que el juicio no puede ser tal / que se pueda hacer exacta diferencia del grano y de la ziza- / ña. Son los sacramentos expuestos al público por lo que es preciso / los reciban buenos y indignos, tolerando Dios esa irreveren- / cia de los malos, para que los buenos tengan ese fructo y provecho: el / que no tubieran separados. Mientras por estar mesclados fue / providencia altísima que el bien sacramental de unos fuese ex- / puesto para todos. Por esto no se afligen en darlos los buenos Ministros, / aun sabiendo ese peligro de irreverencia, con tal de que no sea por / culpa suia, haciendo en ese asumpto lo que les toca. Ni Vuestra Paternidad se / debe afligir ni menos escrupulizar sobre su ministerio hecho para / utilidad del próximo. //11v

\section{Regla VI}

Díceme Vuestra Paternidad que le dé regla para saver hacer lo que toca; porque, / haciendo y cumpliendo bien su obligación, no tendrá que ex- / crupulizar, como ni tienen escrúpulo los ministros de otros sa- / caramentos. Pero su aflicción, dice, está enque no save regla fixa en / que estribar, pues las que dan las summas del moral y mo- / ralistas son tan estrechas que, si el confesor se ha de arreglar por / ellas, de veinte personas encenagadas que oie, apenas se halla una / que se pueda absolber sin escrupulizar. Alo que digo que la Theolo/ gía Moral, las Leies, los Cánones, las Prohibiciones y las Proposici- / ones mismas condenadas, todo todo da dilatación y anchura al que / las penetra. Porque toda la ley, regla, prohibición y ordenanza mira a la / caridad, la que no estrecha, sino dilata. La theología moral se funda en / la Ley de Dios, en los sagrados cánones y papales decisiones. Y ¿qué / pretende la Yglesia en sus ordenazas? No otra cosa, como fin úl- / timo, que la salbación del que confiesa, y que el sacramento se dé de modo / que le sirva para la salud del alma. Deque se ve que el confesor que da el / sacramento quándo, y cómo y porqué ve que le conviene al no ser absu- / elto, y ve que le combiene más que no negarlo, lo da según moral, según / moralistas, arreglado al dictamen de la Yglesia, a la intención de los cánones, / al deseo de los papas, y según la intención de Cristo en haber / dejado ese thesoro para salbación de los perdidos. Por esto se da con / prudencia y justicia, fortaleza y templanza. Vea ay, mi Padre Maestro, / nuestras miserias en todo, nuestras (?)ías ${ }^{181}$, que nos lleban de la mano / para que no ofendamus ad lapidem pedem nostrum ${ }^{182}$. Son las reglas / de la direc-

\footnotetext{
${ }^{181}$ Un borrón en el manuscrito impide distinguir la primera letra de esta palabra.

${ }^{182}$ Posible referencia a Mt 4,6: "Quia angelis suis mandavit de te, et in manibus tollent te, ne forte offendas ad lapidem pedem tuum".
} 
ción para obrar bien. Arréglese Vuestra Paternidad aellas y no faltará //32r un punto al moral, ni le quedará escrúpulo en dar la abso- / lución.

Ya sé io eso, dize Vuestra Paternidad, pero mi aflicción está en que, viendo / a las almas tan encenagadas, se me turba y ofusca el ánimo, / y con el enfado e ira que se lebanta por la terquedad de los peniten- / tes, por sus desigualdades, sin razones, rusticidades, desatenciones, / despropósitos, inconrrigibilidad y a veces defensa de sus vicios, se tur- / ba la prudencia para no obrar justamente con fortaleza y templan- / za: me ponen pec(c)atores laqueum, et de mandatis Domini erro fre- / quenter ${ }^{183}$. Esta es mi duda, para la que necesito de regla. Ya Vuestra Paternidad en su / dicho descubrió el mal, y la raíz ya se ve que no es la raíz primaria: / los vicios fatales de los penitentes. Estos son ocasión no más, que / ocasionan la ira y la imprudencia. Pues en verdad que no ai / regla moral, ni cánones, ni theología que diga que se dé el sacra- / mento imprudenter et cum iracundia. Porque la Escriptura nos / enseña que ira viri justitiam Dei non operata ${ }^{184}$. No obstante, de / este mal proprio no ai escrúpulo, y lo ai del mal ageno, no se(a) que / se falte a la theología y a las proposiciones condenadas. Por lo / qual me parece que Vuestra Paternidad use de la templanza para detenerse en / sus ardores; de fortaleza para animarse a trabaxo tan moles- / to y espinoso; de justicia para la ygualdad en lo que se debe al / sacramento, y más al próximo. Con esto, la prudencia alum- / brará para el acierto, y ministar su oficio sin escrúpulo. Esta / regla es la que más le combiene â Vuestra Paternidad, pues en sí mismo / tiene la mala raíz.

Ya veo que mi Padre Maestro quiere saver lo que toca al confesor $/ /^{32 v}$ más en particular, pero oi no puedo más que generalidades. / En común le toca al confesor dar al penitente la doctrina asu / ignorancia, la medicina asus llagas y la absolución al que / la necesita y desea. Esto lo save qualquier moralista; pero no / se deben dar estas tres cosas en cosas arduas. Supongo que se / pueden efectuar bene y melius, y optime vel perfecte ${ }^{185}$. Y vuestra Paternidad / lo que pretende es saber cómo se ha de dar y executar ese todo para / hacerlo bien hecho. Porque el hacerlo melius, y melius, optime, per- / fecte et perfectis(s) ime, toca en don apostólico, más o menos, quando / el Spíritu de la charidad dif(f)usus est in cordibus nostris ${ }^{186}$, y el fuego del / Spíritu Santo seráphico tiene la gracia de convertir a otros con sus / palabras, con sus exortaciones y con las centellas que salen de / su boca por pegarse en las entrañas agenas,

${ }^{183}$ Actitud contraria al "posuerunt peccatores laqueum mihi, et de mandatis tuis non erravi" (Sal $118,110)$.

\footnotetext{
${ }^{184}$ St 1,20. Variante: "Ira enim viri justitiam Dei non opertur".

${ }^{185}$ Gradualidad que un escrupuloso no sabe calibrar.

${ }^{186}$ Rom 5,5. Variante: "Diffusa".
} 
derritiéndose las / piedras más duras como cera blanda. Ô ¿qué don? ¿Qué ministros estos? / ¿Qué celestiales confesores? No somos nosotros tales; pero / procuremos acercarnos â esta altura, haciendo bene el oficio / con provecho proprio, y si se pudiese el ageno quanto estubie- / se â nuestro alvedrío.

Vuelbe Vuestra Paternidad a instarme sobre qué doctrina, qué medicina, y la ab- / solución quando convenga darla o negarla para hacerlo todo bene y como / se manda, para quedar seguro en conciencia. Pero si se ha de hablar / la verdad sin tergiversación, lo que Vuestra Paternidad desea saver únicamente / es ese tercer punto de la absolución. Ese es el grande río como / el de Ezequiel, que travadari non potest, porque eso de la doctrina co- / mo que es arroio, que llega a normas que usque ad $\operatorname{talos}^{187}$, o quizá usque ad femo- / $\mathrm{ra}^{188}$ para darles a los llagados medicina. No ai en eso para nadie dificul- //33r tad, nadie escrupuliza ni juzga que es tan ignorante que no sepa en- / señar lo que conviene, dar medicina aun a llagas gangrenadas. ¿Có- / mo escrupulizaran los confesores sobre doctrina los que (como Vuestra Paternidad usa) / la da a los penitentes, y tanta y con vehemente esfuerzo hasta can- / sarse y machacarlos? Y no obstante, es lo más difícil para el acierto. / Porque la doctrina y medicina tocan al confesor, y por eso nacen de / caudal proprio de su conciencia y de su virtud, de lo que, si la presun- / ción no le engaña, es preciso que dude de ambas cosas. Pero la abso- / lución no es de caudal proprio, ni depende de su virtud ni esfuerzo. Es / virtud y riqueza del Crucificado, que depositó en el sacramento la que reparte / sin trabajo ni escrúpulo según la intención del amo, cuio es el Thesoro; / y no obstante, ai seguridad en dar doctrina y medicina âqualquiera, ense- / ñando aveces importune lo que no conviene, ô respecto de las personas / o respecto de su estado, condición y vicios, ô respecto al tiempo, circuns- / tancias, y a lo que necesita el que oie con ociosidad, inutilidad, y despro- / pósito, y aun con enfado y daño del penitente, el que suele con la / doctrina empeorarse, como sucedió con el sacerdote que Vuestra Paternidad me / dice, y en quanto a la medicina, nadie juzga que la da mala, aunque sean / cosas tan arduas a la persona y a la calidad de la llaga tan im- / portunas que se ve que por lo arduo no llegarán â efecto, y / respecto de aquellos males es medicina imposible, y queda / el confesor consolado conque puso un vello remedio con so- / lo haberlo mandado. Esto es como el que, estándose haogan- / do, pidiese la mano a otro para evitar el peligro, y le dixese mui / confiado en el consejo que mejor era que saliese por su pie por / cima de las aguas, mandándole ese prodigio como Cristo en //33v

${ }^{187} \mathrm{Ez} 47,3$.

${ }^{188}$ Ex 28,42 . 
otra ocasión a san Pedro ${ }^{189}$. De aquí se ve que llamar Vuestra Paternidad al sa- / cramento de la pentiencia espada tasajante y afilada que le attemoriza, no / es por la doctrina, ni medicina, que toca dar al confesor, sino por la ab- / solución sola, como si Cristo lo hubiese instituido in pernitiem popu- / lorum, y para degollar con esa espada al pobre ministro que, con buena / charidad, se dedica â ese trabajo, y como si fuera espada de dos fi- / los, qualis est sermo Dei penetrabilior omni gladio ancipiti ${ }^{190}$, con- / tra los pecadores, y no contra los pecados ${ }^{191}$, siendo como es para segregar / las carnalidades y manchas del alma y del espíritu, pertingens / usque ad divisionem animae ac spiritus ${ }^{192}$, y como otro baptismo en que / queden anegados los vicios y el pecador, salbo ${ }^{193}$. Ciertamente, el dar / la absolución al reo, quitar grillos y cadenas al captibo, bautizar / al sucio para que quede limpio, dar un thesoro al pobre miserable, de- / satar las ligaduras para que el sentido quatriduano ligatis ins- / titis po(s)sit abrire in domum aeternitatis ${ }^{194}$, cubrirle turpitudinem nu- / ditatis vestimentis albis ${ }^{195}$, dar la mano para que salga del cieno a / donde estaba atollado el próximo, quando este da la suia para recibir esa / misericordia, y en una palabra, ser misericordioso con el próxi- / mo según el grande encargo de Jesucristo en su mandato nuebo: / todas estas virtudes que se practican en dar la absolución al pecador / son para Vuestra Paternidad espada afilada que sobre su cuello está puesta, espe- / rando solamente para descargar el golpe, ver si el confesor absuelbe. / Padre mío, si eso fuera assí, ¿qué fuera de la feê? ¿Adónde está la / promesa antigua de la divinia palabra, que dize: $E a$ dem mensura, / qua mensi fueritis, remetietur vobis ${ }^{196}$; et Beati misericordes, quoniam ipsi misericordiam consequentur ${ }^{197}$ ? No obstante, el cuidado es- //34r

${ }^{189}$ Cf. Mt 14,22-23.

${ }^{190} \mathrm{Hb} 4,12$. Variante: "Vivus est enim sermo Dei, et efficax et penetrabilior omni gladio ancipiti".

${ }^{191}$ Adviértase aquí, invertido, el famoso aforismo agustiniano: "Et quoniam nemo natura, sed quisquis malus est, vitio malus est: perfectum odium debet malis, qui secundum Deum vivit, ut nec propter vitium oderit hominem nec amet vitium propter hominem, sed oderit vitium, amet hominem. Sanato enim vitio totum quod amare, nihil autem quod debeat odisse remanebit" (Agustín de Hipona, ciu. Dei 14,6, PL 41,409; basado en el Sal 139,22).

${ }^{192} \mathrm{Hb} 4,12$.

${ }^{193}$ En la línea de la lectura expoliativa del bautismo desde el pasaje del diluvio, ya referida, el bautismo de agua sana destruyendo los vicios de los bautizandos. Simbolismo del agua en cuanto fuerza destructora (cf. M. Eliade, Images et symboles, Gallimard, París 1972, 199-201).

\footnotetext{
${ }^{194} \mathrm{Cf}$. Ecl 12,5.

${ }^{195}$ Cf. Ap 3,18.

${ }^{196}$ Lc 6, 38b.

${ }^{197}$ Mt 5,7.
} 
crupuloso en Vuestra Paternidad es dar la absolución; y ninguno ai sobre la en- / señanza y la medicina, que son demás cuidado que la judicatu- / ra, que son los tres oficios que tocan al confesor en ese ministerio? /

Por esto, el Padre Maestro no pregunta de esas cosas nada, porque / de esas cosas no escrupuliza. Es así que, aunque Vuestra Paternidad preguntara sobre / ellas, no tubiera qué decir ni conqué responder. Muchas exor- / taciones ai escritas, muchas reglas y precapciones para la / medicina, muchas recetas saludables para la perseverancia; / pero, ¿qué es lo que toca decir? ¿Cómo? ¿A quién? ¿En qué ocasión? ¿En qué / oportunidad? Singularmente la dosis, el tiempo, la moda de aplicar / la medicina, no sea que la doctrina y medicamento bellísimo que está en / la botica de los libros, para un efecto para una llaga, para un sugeto, para un / tiempo, se aplique adiversos acasos en que la atriaca ${ }^{198}$ se volbió antimonio ${ }^{199} /$ con que se empeoró el enfermo. Estas dudas que ocurren cada día en / la diversidad de cada persona hacen no poder io dar regla segu- / ra en la práctica. Unos anteojos son vello consejo para el corto de / vista, un anillo de diamantes medio provado por todos para ador- / nar los dedos. Pero póngase los anteojos en los dedos y el anillo / en los ojos, y parecerá ala vista una práctica ridícula y fea. No / se fíe Vuestra Paternidad tanto de sus doctrinas y esfuerzos a diestro y sinies- / tro, que más valen cuatro palabras a tiempo, i oportunas, que mil im- / portunas al tiempo, a las personas y alas llagas. El púlpito es para pre- / dicar, el confesionario para lo que es; aquí se oien las confesiones de los / arrepentidos con lo que se les exortó en el púlpito. Si en el confeso- / nario conbiene predicar âveces, pero según el tiempo, es oportuno, / sin hacer molestia a nadie. El Padre Maestro confiesa en una maña- $/ /{ }^{34 v}$ na a quatro personas, y predica quatro sermones largos sin que / les sirva a infinita tropa, que con desazón y molestia aguarda. Pero, / ¿no fuera más prudencia que Vuestra Paternidad los juntara en una Yglesia / y les predicara a todos en el púlplito y, aunque fuera largo tiempo, / oieran con gusto estando de espacio? Mas acada uno solo y / largo tiempo, con perjuicio de tantos en tan importuna ocasi- / ón, no es prudencia, ni justicia, sino destemplanza en dar / doctrina por no saver arreglarse al oficio con fortaleza.

Es verdad que le toca al confesor la doctrina, alumbrando la / ignorancia del que confiesa. Pero, aunque toca semper, mas no / pro semper, sino pro aliquando, quando conviene, maior / obligación ai para la integridad de la confesión, que aun para la doc- / trina, porque la integridad de la confesión es parte

${ }^{198}$ Palabra en desuso: Confección farmacéutica antigua, compuesta de varios elementos, como el opio, y aplicada a las mordeduras de serpientes y culebras (cf. https://definiciona.com/atriaca/).

${ }^{199}$ Palabra no del todo legible. Optamos por esta en virtud de su carácter perjudicial para la salud. 
integral / (alomenos) del sacramento, lo que no tiene la doctrina, que sirve / solamente de disposición previa; yno obstante, vemos que se dispen- / sa aveces; y en la Yglesia antigua, ia dixe, se dispensó para muchos / mortales que se reputaban por quotidianos, y en hombres lábiles por / sus malas costumbres, difíciles de evitarse. Y oy en muchos casos se da / el sacramento sin esa integridad de la confesión, porque esa dispensa la / piden las circunstancias. Y la Yglesai ningún pecado manda se con- / fiese para la confirmación, ni órdenes, ni matrimonio, ni para el santo / Ôleo; y aunque obliga al pecador a confesarse por mandato de Dios, / mandato que obliga semper, pero no pro semper. Ni la Yglesia obliga / â nadie â confesarse, sino en tres ocasiones: cada año por la / Quaresma, quando aia de recibirla Eucharistía y quando ai peligro de morir, / de asistir al Tribunal de Dios. Esto vemos aun en la confe- //35r sión, ¿con quánta más razón podrá haver, y ai frequentemente, cir- / cunstancia en que se dé el sacramento sin la doctrina, aliunde ne- / cesaria y utilísima?

Ciertamente, ai ocasiones en que no solo no obliga a dar doctri- / na, sino que daña, sino es quizá poca y con prudencia. Los doctos no / quieren ser enseñados, ni vienen al confesor como maestro; no creen / que son inferiores aél para ser discípulos del que desprecian por su lite- / ratura en su ánimo. Esa es menester enseñar al docto y maestro / en lo que necesita para sus vicios, una doctrina superior, y con tal / altura y maña prudente que el docto soverbio se humillara yse / reconociera inferior â tanta luz. Quizá de haber Vuestra Paternidad faltado â / dar la enseñanza que convenía al sacerdote, que medize, sucedió sa- / lir con la doctrina furioso y empeorado. Unas personas ai que, si / se les dize algo, se acortan, callan y empeoran, y otras ai que si / no se les reprehende mucho, juzgan que no han confesado. Otras / ai incapaces de enseñanza por muchas cosas, o sea, por no tener en- / tendimiento, ô por no haber tenido cultivo en su crianza, sin oír / nada, ni en esquelas, ni en púlpitos, criados y educados como / bestias, que aun no entienden el idioma con que se les enseña. Ô / muchos por estar sepultados, y atollados, en los vicios con los que caen / en un sueño profundísimo adonde era lexos de las verdades de / la feê, por más que se les quiera con ellas refrenar; otros por sor- / dos, y mudos otros, y otros semifatuos, alocados, simples, balbucientes, / turbados y temblando de aquel mal paso, y nada atienden sino / a salir del estrecho, y que no se les olbide nada de las culpas que / traen pensadas. Vaia mi Padre Maestro adetenerse con estos predicándo- $/ /^{35 \mathrm{v}}$ les con esfuerzo, y perder el tiempo inútilmente, el trabajo y la salud / del cuerpo con los repetidos ahíncos, y lo peor es, con esa impru- / dencia charitativa faltar al bueno y recto usso dese ministerio.

Es preciso sea diversa la doctrina, aun quando convenga darla. / Es menester esté el ánimo pacífico y limpio para que Dios alumbre la prudencia en lo 
que se habla, para no errar en el quánto ni en el cómo / ni en lo que toca para la corrección y la instrucción, que son dos cosas / â que se reduce la doctrina. La Yglesia no enseña igualmente â todos, dize el Agustino (en el) libro de Moribus Ecclesiae, 31: Ô! Ecclesia / catholica, mater Christianorum verissima, (dize) tu pueriliter pueros, / fortiter jubenes, quiete senes, prout cujuscumque non corporis / tantum, sed et animi (a)etas est, exerces et doces ${ }^{200}$. Y vuestra Paternidad, con los / encenagados que son en el ánimo pueri, y aun denиo $n_{a t i^{201}}$, y que / aquel día comienzan quizá la buena voluntad para la vida / cristiana, los quiere ia jóvenes y los trata como a fuertes, que- / riendo que sean ia robustos a fuerza de ahíncos, de machacarlos, / quando debe el confesor acomodarse al spíritu párbulo con que traen un solo / initio del temor de Dios, y flaco deseo de su salbación, el que debe / fomentar y acalorar dulciter no se extinga, no exasperarlo, ni / desampararlo para que se pierda, sino abrigar aquella voluntad que dize el / profeta: Dios es quien la prepara, praeparabitur voluntas a Domino ${ }^{202}$, / porque cresca, o alomenos, si se perdiese y apagase aquella llamita, que no / tenga el confesor la culpa por imprudencia. Este es el spíritu de la Yglesia, / y el que enseña la theología cathólica, docere et exercere pueros pue- / riliter; y, en llegando a ser jóbenes en las virtudes, iubenes vero / fortiter, según que la hedad del ánimo de cada uno pidiese. //36r

\section{Regla VII}

La judicatura es la que da al Padre Maestro más cuidado, y fatiga, que la / medicina y enseñanza en medio de ser estas dos más dificultosas. La / absolución, si se ha de dar o no, y el quándo se debe dilatar ô se ha de dar / sin miedo y de prompto, es el gran batallón deese ánimo afligido / y estrecho, quando carga sobre Vuestra Paternidad un dilubio de males de hombres en- / cenagados en sus constumbres, sin ver que se emmienden ni se / corrijan, ni hacer caso de lo que se les dice y reprehende. Qui- / siera el Padre Maestro ver que, con el aspersorio de su doctrina, salían / blancos como la niebe pura â una vida sin mancha. Pero / quis potest facere mundos homines corruptos

${ }^{200}$ Agustín de Hipona, mor. I, 30, 62-63, PL 32, 1336-1337.

${ }^{201}$ Cf. Jn 3,3.

${ }^{202}$ Con la variante "praeparatur", se trata de la traducción de Prov 8,35 conforme a la versión de los LXX. Así la cita Agustín de HiPona en retr. I,10,2, PL 32, 599; 2,1,2, PL 32, 630; c. ep. Pel., I, 18,36, PL 44, 567; II,9,20, PL 44, 585; IV,6,12, PL 44, 618; s. 333,1, PL 38, 1464. La traducción de la Vulgata reza así: "Qui me invenerit, inveniet vitam, et hauriet salutem a Domino". 
de immundo / conceptos semine? Nonné Jesuchristus qui solus est?203. Pues / ¿para qué el Padre Maestro quiere ser más de lo que es? ¿Para qué quiere ex- / ceder su ministerio de confesor, y ministro del único salvador, / haciéndose co-redemptor con él? Esta confianza propria, / (de) presunción altanera y estimación de sus fuerzas, de su litera- / tura y de sus ahíncos forzudos para sacar del lodo a los im- / mundos, es no creer la feê, que dice: Sine me mihil potestis fa- / cere ${ }^{204}$; vanum est vobis ante lucem surgere ${ }^{205}$; non est aliquid qui rigat, neque qui plantat, sed qui incrementum dat Deus ${ }^{206}$. Es creer / poco del sacramento y no esperar en Dios solo, sino en sí / mismo. Y viendo que nada se saca, sino tinieblas y amargas espinas, entra el después y la fuga del ministerio como de / una espada de dos filos. Esto es no conocerse bien Vuestra Paternidad assí / mismo, y sin conocerse un hombre assí mismo no podrá cu- / rar llagas agenas, aun en lo que le toca. Además, por atender //36v â uno ô aotro con conato, diciéndoles mucho, se cansa el cuer- / po, se debilita el ánimo, se amarga y se enflaqueze el spíritu / para continuar con más y más penitentes a los que es preciso, ya / fastidiado, los fastidie, y ni tenga ia fuerza, ni sepa qué decirles. / De lo que sale que, por hacer mucho por uno ô por dos, no haga nada por / muchos, no les diga, ni enseñe prudenter, y los heche a perder / con esas tinieblas, y Vuestra Paternidad quede amargo, cansado, y escrupuloso. / Mexor era hacer lo que dice el Psalmista: Fortitudinem meam ad te / custodiam $^{207}$, dando la doctrina con templanza para reserbar fuerzas al / camino que queda, viendo que adhuc magna tibi restat via ${ }^{208}$. Ôsi / Vuestra Paternidad no quisiere salir cansado de confesar â muchos, y muchísimos, / en días de concurso, jubileos y mundaciones de gentes, que oprimen, / sofocan y desazonan, tiene el caso eficaz remedio, combiene â / saber: no tomar la carga pesadísima aduna sobre sus ombros / proprios, sino sobre los agenos, sobre los del Gigante omnipotente, / que no a cien pecadores, ni a cien mill, millares; sino al mundo / universo de todos los siglos naufragó en el dilubio de males, y / abominaciones, lo tomó sobre sus ombros a peso, y lo sacó â / salbo. Esta feê diera paz tranquila, diera fuerzas y pru- / dencia para solo tocar la carga con la mano, en lo que solo toca / al ministro, sin cargarse con todo el peso â nuestra

${ }^{203}$ Job 14,4. Variante: "Quis potest facere mundum de immundo conceptum semine? Nonne tu qui solus es?".

${ }^{204} \mathrm{Jn} 15,5$.

${ }^{205}$ Sal 126,2 .

${ }^{206} 1$ Cor 3,7. Variante: "Itaque neque qui plantat est aliquid, neque qui rigat: sed qui incrementum dat, Deus".

${ }^{207}$ Sal 58,10.

${ }^{208} 1$ Re 19,7. Variante: "Grandis enim tibi restat via". 
flaqueza / insoportable, y solo puede aquel Gigante que portat omnia / verbo virtutis suae, purgationem pec(c)atorum faciens ${ }^{209}$.

Esto es lo que ignoro, dice el Padre Maestro, qué cosa es tocar la car- / ga con sola la mano sin cargarla sobre el ombro, ô no hacer sino / lo que está a nuestra mano, o lo que toca solamente a nuestro ministerio; ¿por // ${ }^{37 \mathrm{r}}$ qué, en llegando al oficio de juez, en que ha de sentenciar, no sé / lo que debo hacer sobre dar o negar la absolución? A lo que / digo que es cosa fácil, y no es tan ardua como Vuestra Paternidad la concibe. / Dixo san Agustín tratando de Ecclesiástica disciplina: Habe cha- / ritatem et fact quidquid vis ${ }^{210}$. Como Vuestra Paternidad ame a los penitentes, / haga lo que quisiera, o dé o niegue la absolución, porque, siendo / la charidad la que sentencia, será bien manejada causa, quia charitas patiens est, benigna est, non agit perperam ${ }^{211}$. Pero como / están mezclados, dize mi Padre Maestro, los justos con los réprobos, / con estos incorregibles, dudo el absolverlos, y no sé cómo la cha- / ridad misma los absuelba. Es verdad que están mesclados, y que / está dicho: Nemo potest corrigere, quem Deus derpexerit ${ }^{212}$. Pero por / lo mismo que están mesclados, e ignoramos qui sint eius vel / non, y nos está prohibido el separar antes de tiempo la cizaña / del trigo, tiene la charidad un dilatado campo para llober / misericordias, super bonos et malos, et super justos et injustos ${ }^{213}$. I Están mesclados buenos y malos; assí los adunó en una Yglesia / la altura altísima de los consejos de la mui profunda sabiduría. / Y ¿para qué sufre a los malos? Para que sean buenos y escogidos, desechan- / do solamente por último a los tercos. Vea aquí Vuestra Paternidad lo que haze la / charidad, aiudar con la doctrina y sacramentos â los malos, / lo que, aunque parescan â nuestros ojos mui perdidos, quizá Dios los / mira oculo vigilante para que no se pierdan, se enmienden y se / rindan, y, como confesando ia se rinden, ia obedecen, ia propo- / nen, ia comienzan la salud por el initio de una buena vo- / luntad, la charidad por si acaso le sirbe el sacramento, lo fran- //37v quea, aun al impío, como quien larga la mano para que salga del / cieno; y si por fin él es terco, es mucha gloria del confesor aver / sido charitativo con

${ }^{209} \mathrm{Hb} 1,3$.

${ }^{210}$ Quizá se aluda al famoso adagio agustiniano: "Dilige, et quidquid vis fac" (Agustín de Hipona, s. 163 B, 3: Miscelánea agustiniana, Romae 1930, 1, 214; ep. Io. 7,8, PL 35, 2033.

${ }^{211}$ 1Cor 13,4. Variante: "Caritas patiens est, benigna est. Caritas non aemulatur, non agit perperam, non inflatur". Beda el Venerable, "Tabernaculo et vasis eius, ac vestibus saacerdotum”, lib. III, cap. 11: J. A. Giles (ed.), The Complete Works of Veneraable Bede in the original latin, VII, Commentaries on the Scriptures (London, Whittaker and \&, Ave Maria Lane,1844), 353.

${ }^{212} \mathrm{Ecl} 7,14$. Variante: "Considera opera Dei, quod nemo possit corrigere, quem ille despexerit".

${ }^{213}$ Mt 5,45. 
el próximo, aunque perdido; na haze, pues, da- / ño la mescla de malos con buenos, debiendo la charidad exten- / derse a todos mientras ignora el éxito de cada uno.

De aquí sale sin escrupulizar la práctica de la absolución, / porque, si absuelbe, es la charidad la que manda, y, si niega la absolu- / ción o la dilata, es la charidad misma la que assí lo executa, / y siempre lo haze juste et prudenter, porque ambas cosas se / practican charitative, y es la razón a priori y fundamen- / tal, porque la charidad mira ha hacer bien al próximo, y / bien el grande y aun el único, que se llama bien, qual es la sal- / bación o eterna felicidad. Por esto, quando la charidad puede co- / nocer si la absolución hará para ese fin provecho alguno al / próximo, la da sin miedo, y aun con gusto. Pero si ve que el reo le / es más provechoso negarle, ô dilatarle la absolución charitative, / sin congoxa ni fatiga la suspende dulciter. Pero como la cha- / ridad a veces no conoce (dize mi Padre) lo que fixamente al penitente / le combiene, ai que temer no se falte a la reverencia debida / al sacramento dándolo al indigno, sobre lo que la Theología mo- / ral nos pone tanto miedo. Yo digo al Padre Maestro que estoi con- / tento con solo el que crea que, quando la charidad viese que al reo / miserable más le combiene darle el sacramento que negarlo, / entonces lo dará Vuestra Paternidad sin escrúpulo, porque es ia más fácil el / saver (según podemos saver acá metidos en ignorancias y / tinieblas) quándo más le combiene al próximo, uno que otro, darles //38r el sacramento, ô negarlo. En lo demás de la reberencia / debida al sacramento. no crea mi Padre que se falta nunca quando / se da con prudencia charitativa, porque solamente se faltará al / respeto debido al sacramento quando se desordenara este del fin / a que fue instituido; el próximo y su salbación es el fin suio, si- / endo el sacramento solamente medio que se manda ministrar para ese / fin; luego solamente será falta de respeto, quando se desordenase de su / fin, dándolo o negándolo en daño del próximo; luego, quando se da / o se niega porque se ve que uno u otro le aprovecha, se honrra / al sacramento y no se desprecia ni se le falta a la reverencia de- / vida, antes se le da orden, que es su maior honor y culto, según / la intención del Jesucristo. Ni otra cosa enseña la theología / ni jamás las condenadas ni cánones decretales prohíben que / se dé el sacramento charitate et prudencia, la que dicta que al / hombre se le dé el sacramento (que es suio por dádiva de Jesucristo / in bonum miserorum, sed credentium), quando de él saca provecho al- / guno, y ningún daño. Antes se ve que los cánones y los theólogos, / sus intérpretes, los Santos Padres, los Papas y la práctica de la Yglesia, / no enseñan otra cosa que la charidad y salud de las almas, / en sus leies, ordenanzas, prohibiciones, para la administra- / ción de los sacramentos con orden debido. $\mathrm{Ca}(\mathrm{l})$ mará a Vuestra Paternidad si / sobre esto se acumularan textos (aun sagrados) de todos, singu- / larmente del Agustino, el que 
continuamente inculca con su pluma / esta doctrina. Pero baste decir lo que, buscando el célebre co- / lector de los cánones, decretos y concilios, dice en el libro 19, capítulo 8, y es / assí: Haec omnia de canonibus, et (de) sanctorum Patrum sententiis //38v de Hieronimo, et Augustino, (y otros) et ex penitentiali Roma- / no vera col(l)igimus; sed quia nulli neces(s)e sit perire scien- / tibus et intelligentibus animarum medicis haec temperanda / commisimus ${ }^{214}$. Adonde se ve que esta(e) gran canonista comete / todas las reglas al templado usso que combiene según la / inteligencia de los sabios médicos de las almas.

El otro insigne collector de los cánones (uno y otro / antes de Graciano ${ }^{215}$ ),

${ }^{214}$ Puede que el autor se refiera a Bucardo (Burkhard) de Worms (965-1025), quien, al ser nombrado obispo de esta diócesis, recopiló de veinte libros los cánones que sirvieran para mejorar la vida eclesiástica de aquella, reformando los modales, pues le preocupaban el orden material y la conducta moral del clero, e intentando resolver los conflictos que permanentemente surgían entre la Iglesia y las autoridades civiles, entre el Papa y los obispos, entre los clérigos y los monjes. Dicha compilación, de corte moderado y con evidentes fines didácticos, recibió el nombre de Decretorum Libri Viginti, popularmente conocido como Decretum o Brocardus (1012-1023). De los veinte capítulos que componen el libro, el decimonoveno, destinado a los cánones vinculados con la administración de la penitencia, adquiere un nombre propio: Corrector sive Medicus, catalogado por G. Austin "penitencial anotado". Aun con todo, el autor de la Respuesta también puede aludir a la compilación anónima Collectio Anselmo dedicata (c. 883-897), segunda fuente importante de la obra de Bucardo, que le inspira, además de contenidos, la estructura de la obra. Para algunos autores, el obispo de Worms, que sigue bastante fielmente esta fuente, acomete significativas omisiones, como el texto aquí citado por nuestro autor (cf. Augustini Theineri, Disquisitiones criticae in praecipuas canonum et decretalium. Continuatio, Collegio Urbano, Romae 1836, 311; G. Austin, Shaping Church Law Around the Year 1000. The Decretum of Burchard of Worms, Routledge, London 2009; F. Gagnon, Le Corrector sive Medicus de Burchard de Worms (1000-1025): présentation, traduction et commentaire ethno-historique, Monteral 2010: https:/papyrus.bib.umontreal.ca/xmlui/bitstream/handle/1866/4915/ Gagnon_Francois_2011_memoire.pdf?sequence=4\&isAllowed=y). Otra recopilación reseñable de la época, que bebe del Decreto de Bucardo, es la Collectio canonum (1081-1086) de Anselmo de Baggio el Joven (1036-1086), obispo de Lucca, obra de referencia en la implantación de la Reforma Gregoriana (cf. K. G. Cushing, "Polemic or Handbook? Recensión Bb of Anselm of Lucca's Collectio Canonum": B. C. Brasington and K. G. Cushing (eds.), Bishops, Text and the Use of Canon Law around 1100, Ashgate, Burlington 2008, 69-78; F. Martínez Martínez, "La superioridad del derecho divino en el pensamiento pregraceaneo: Una visión de las colecciones canónicas medievales": Ius canonicum 89 (2005) 213-222).

${ }^{215}$ Graciano es todavía un desconocido para la crítica histórica. Aunque ignoramos sus orígenes, formación, carácter, estatus o relación con Inocencio II, hoy se afirma que estaría vinculado con los canónigos regulares de París (cf. G. Mazzanti, "Graziano e Rolando Bandinelli”: Studi di Storia del Diritto 2 (1999) 79-103). De lo que no cabe duda es de que trazó "el grandioso proyecto de concordar los cánones discordantes. Con este Decreto empieza de nuevo la historia del Derecho canónico”, al que se le otorga autonomía y personalidad específica (cf. F. J. Cardona Vidal, Los diecisiete artículos de Richard Kane, Ediciones Universidad San Dámaso, Madrid 2018, 129). De aquí nació Concordia discordantium canonum, o el Decreto de Graciano, que suele datarse en el año 1140 y que ha de considerarse un proyecto comprehensivo y didáctico, en cuanto sintetiza y ordena con coherencia la tradición canónica anterior a él (recopilaciones de Bucardo, el Dictatus Papae de Gregorio VII, la 
el obispo $\mathrm{Ybo}^{216}$, dice también en su pró- / logo: Quicumque Ecclesiasticus Doctor (...) regula ita interpretatur / et moderatur, ut ad regnum charitatis cuncta (...) referat nec / peccat, nec errat, cum saluti proximorum consulens ad finem / sacris institutionibus debitum pervenire intendat; y cita el / dicho del Agustino ia mencionado, undi dicit Augustinus: Habe / charitatem et fac quidquid vis ${ }^{217}$, en que se ve en poco explicado todo / mi pensamiento: que no se desonrra el sacramento sino quando / se desordena de su fin, que es el bien del próximo, desuerte que el / darlo o negarlo sea para su utilidad; y si en uno o en otro no se / mira a la salud del próximo, se desprecia y se comete sacri- / legio. Porque el pecado, qualquiera que sea, no es otra cosa que desordenar / las cosas de sus fines; y la rectitud o bondad es guardar ese / orden. Assí, san Agustín, en el libro de las 38 cuestiones, cuestión 30, / dice assí: Omnis humana perversio, quaem est virtium, dicitur est / haec, velle uti fruendis;

Colección de los 74 títulos, la Colección de Cánones de Anselmo de Lucca y de Yvo de Chartres, la colección del cardenal Deusdedit). Cf. D. Sequeira, Os presbiteros diocesanos e o seu envolvimiento na política: proibição e excepção, Editrice Pontificia Università Gregoriana, Roma 2004, 51-57; J. M. Viejo-Ximénez, "La composición del decreto de Graciano": Ius canonicum 90 (2005) 431-485; C. Larrainzar González, "La investigación actual sobre el Decreto de Graciano": Annaeus 2 (2005) 67-92.

${ }^{216}$ Yvo de Chartres (1040-1116), uno de los representantes más relevantes de la cultura francesa del momento y uno de los que aportó luz para resolver la denominada Guerra de las investiduras, ha pasado a la historia como el autor de tres grandes recopilaciones jurídicas, elaboradas entre 1094 y 1096. Estaría primero la Tripartia, “colección cronológica... de cánones, textos patrísticos y normas jurídicas tomadas del derecho romano y franco, que se enmarca dentro del espíritu usual de compilación existente en las colecciones anteriores"; el Decretum, florilegio jurídico que abarca diecisiete libros; y la Panormia o resumen de la obra anterior que, a diferencia de ella y de la Tripartia, aporta cierta novedad al tratamiento de las fuentes canónicas: no se es ya solo una colección de textos, sino que se eligen y ordenan de manera que adquieren cierta ligazón. Como dice F. Martínez Martínez, "se recoge, se depura, se selecciona, se integra" (F. Martínez Martínez, "La superioridad... 222-223, cf. 222-231). Por ello, habría que considerarse esta su obra más importante, aunque "sea tributaria del Decretum y oper(e) con los mismos textos" (cf. Id., "Orto y ocaso de una definición. El concepto de derecho en las colecciones canónicas anteriores a Graciano": Anuario Mexicano de Historia del Derecho 18 (2006) 457, cf. 450-458). Sin embargo, esta versión tradicional ha sido rebatida por C. Rolker, quien sostiene que Ivo de Chartres no recopiló la tercera obra, ni escribió el famoso Prólogo al Decretum, reproducido en Panormiae. Esta hipótesis replantea el influjo de este personaje en el desenvolvimiento, no solo del derecho canónico, sino de la reforma gregoriana, la escolástica y la retórica (cf. C. Rolker, Canon Law and the Letters of Ivo of Chartres, Cambridge University Press, Cambridge 2009).

${ }^{217}$ Pueden encontrarse el texto y un comentario al mismo en B. C. Brasington (ed.), Ways of Mercy: The Prologue of Ivo de Chartres. Edition and Analysis, LIT Verlag, Münster 2004 (véase, p. e., p. 8, n. 18); C. Rolker, Canon Law... 165, n. 8; F. Martínez Martínez, "La superioridad... 223. Sobre el papel relevante de la caridad en la hermenéutica de la ley para san Ivo, siguiendo la doctrina agustiniana y especialmente 'el reino del amor' referido en Agustín de Hipona, doc. Chr. III,XV,23, PL, 34, 74, cf. B. C. Brasington (ed.), Ways of Mercy... 26-29. 
atque utendis frui. Et contra omnis or- / dinatio, quae est virtus, dicitur est haec, fruendis uti, utendis frui ${ }^{218}$. I En que se ve que desordenar los medios, haciéndolos fines, ô a estos hacerlos medios, es lo que se llama perversión ô pecado $^{219} . / / /^{39 r}$

No puede darse el sacramento sacrilege quando se da honeste. Bien honesto se dize aquello quod propter se ipsium / expetendum est ${ }^{220}$. El bien utile es aquel quod propter aliud. / Del mismo modo se dize que gozamos de la cosa quando de ea re / capimus voluptatem ${ }^{221}$. No hablo aora de la honestidad úl- / tima, a las que todas las cosas honestas han de ser referidas. / Esta es una inteligible velleza, que se dice espiritual, y respec- / to de ella, la utilidad es la divina providencia, que hizo to- / das las visibles vellezas. Por eso, aunque ai tantas visibles / hermosuras, las que no propriamente se llaman honestas. / Pero aquella primaria honestidad bella y hermosa, de a- / donde tienen su velleza las cosas visibles, ella no es visible. / De aquí viene que ai muchas cosas útiles y visibles, pero aque- / lla utilidad por la que nobis prosunt ${ }^{222}$ no es visible, y se dice Pro- / videncia divina. Todos sabemos que con el nombre de cosas visi- / bles se comprehenden todas las cosas corporales. Combiene, /

${ }^{218}$ Agustín de Hipona, div. qu. 30, PL 40, 19: "Omnis itaque humana perversio est, quod etiam vitium vocatur, fruendis uti velle atque utendis frui; et rursus omnis ordinatio, quae virtus etiam nominatur, fruendis frui et utendis uti".

${ }^{219}$ En su argumentación, el autor juega con dos ideas centrales en el pensamiento agustiniano, íntimamente relacionadas. Por una parte, el concepto del ordo amoris (cf. J. I. Sánchez Gordillo, "La virtud y el orden del amor en La ciudad de Dios de san Agustín": Augustinus 200/201 (2006) 123-186; D. Natal Álvarez, "El ordo amoris en san Agustín": Revista Agustiniana 149 (2008) 527551; A. D. Román Ortiz, "El orden del amor. San Agustín y la ética de los valores de Scheler": Augustinus 228/229 (2013) 119-161), y la dialéctica del uti y el frui como la doble dimensión del amor humano (cf. I. López, "Uti y frui: la doble dimensión del amor en el pensamiento de Agustín de Hipona": Cuadernos de teología 2 (2016) 104-125; R. Canning, "The Augustinian uti/frui. Distinction in the Relation between Love Neighbour and Lovefor God": Augustiniana 33 (1983) 165-231; K. Y. Bruchill-Limb, "The actuality of Augustine's distinction between uti and frui": Augustiniana 56 (2006) 183-197). De ellas se deriva el concepto agustiniano de pecado como errar en el horizonte del amor, llegando el ser humano al amor sui y la consiguiente aversio Dei (cf. Agustín de Hipona, Simpl. I,2,18, PL 40,122-124; civ. Dei 12,6, PL 41, 353-355; 14,18, PL 41,456; lib. arb. I,16,35, PL 32,1240; II,19,53, PL 32,1269). Adviértase que el Hiponense tan solo juega con el significado de uno de los verbos hebreos más utilizados en la Escritura para referirse al pecado ( $\left.h t^{\prime}\right)$, que significa precisamente 'errar un objetivo, deviarse, caer' (cf. Jc 20,16; Pr 19,2; R. Knierim, " $h t$ ', errar, pecar": E. Jenni y C. Westermann (dir.), Diccionario teológico manual del Antiguo Testamento, I, Cristiandad, Madrid 1978, 755-765).

\footnotetext{
${ }^{220}$ Agustín de Hipona, div. qu. 30, PL 40,19.

${ }^{221}$ Ibid. Variante: "Frui ergo dicimur ea re de qua capimus voluptatem".

${ }^{222}$ Ibid.
} 
pues, frui pulchris invisibilibus, id est, honestis ${ }^{223}$. Pero, de las cosas / últiles, no gozar, ni usar, usar de todo según cómo y del modo / que se debe usar. Por esto usar de una cosa es proprio de racio- / nales, el gozar de ella es común a las bestias. Estas gozan et / fruuntur cibo, et potu qualibet corporali volupta$t e^{224}$. Pero no / se dice que usan de las cosas que detestan. Porque es menester ser / hombres sabios para saver adónde, a quién y qué cosa es lo que se ha / de referir y ordenar. Por eso se dice que abusar de la cosa y abutuntur / ea que no usan bien de ella, ni la dirigen, ni la ordenan, y la profanan. / Ni anadie aprovecha aquello de que mal usa. $/ /^{\beta 9 \mathrm{v}}$

Vea aquí Vuestra Paternidad lo que es pecado frui utendis, vel uti fruendis, que es lo / mismo que desordenar los fines y medios, permutando unos por / otros. Aora pues, el mismo san Agustín, en el libro De doctrina christiana, / capítulo 10, dize: Non (autem) praecipit Scriptura nisi caritatem, nec culpat / nisi cupiditatem, et eo(dem) modo informat mores hominum. $Y$ añade: / Caritatem voco motum animi ad fruendum (Deum propter / ipsum, et se, / et proximo prop- / ter Deum; cupidi- / tatem autem motum / animi ad fruendum se $)^{225}$ se et proximo et quod- / libet corpore non propter Deum ${ }^{226}$. Desuerte que la charidad orde- / na todas las cosas utens utendis, et non fruitur, nisi fruendis / vel honestis ${ }^{227}$, y por eso charitas non agis perperam, antes es la / honestidad y virtud misma. Y al contrario, la concupiscencia / todo lo desordena, utens fruendis, et fruens utendis. Colija / de aquí el Padre Maestro cómo será sacrilegio ni desprecio de el sa- / cramento quando este se da honeste charitative y con orden al pró- / ximo, que es el fin que está ordenado, y se usa deel propter aliud, y si se da con gozo, y fruimur illo, no es propter ipsium, sino prop- / ter bonum proximi, lo que no es proprie frui, sino uti con orden. / Ni crea Vuestra Paternidad que enseñan otra cosa la Theología moral en las re- / glas de su dirección, ni los Papas en sus Bullas, ni los Padres / en sus doctrinas.

${ }^{223}$ Ibid.

${ }^{224} \mathrm{Ibid}$. Variante: "Et frui quidem cibo et qualibet corporali voluptate".

${ }^{225}$ Este texto aparece en glosa marginal, muestra de uno de tantos errores típicos de la trascripción. El texto original reza así: "Deo propter ipsum et se atque proximo propter Deum; cupiditatem autem motum animi ad fruendum se".

${ }^{226}$ Agustín de Hipona, doct. Chr. IV,10,15-16, PL 34,96.

${ }^{227}$ Vuelve a jugar, parafraseándolas, con las ideas tomadas de Agustín de Hipona, div. qu. 


\section{Regla VIII}

Aun dilatando io ese animo per spatia charitatis (Padre Maestro) adhuc angustiatur tibi vasa carnis tenebris, et scru- / pulis ${ }^{228}$. Porque dize mi Padre: ¿quándo sabré que la absolución le es útil al / próximo para darla charitati$v e$ ? Veo a muchos con mushísimos / males y abominaciones, y veo no traen las partes todas que / el tridentino pone precisas para el sacramento, que son contrición, / confesión y satisfacción. Por eso no me parece que es charidad $/ /{ }^{40 r}$ de el próximo; sino irrisión del sacramento el recibir aestos / perdidos. Adhuc modicum lumen inte est ${ }^{229}$, Pater mi(hi). Muchas / cosas toca Vuestra Paternidad en pocas palabras y tenebrosas. Padre mío, si Vuestra Paternidad / no distingue el oficio de confesor, y lo que le toca por tal de lo / que le toca al reo, al penitente, al pecador, siempre estará / con escrúpulos, cargándose con los pecados agenos. / Ala ino- /cencia, charidad, bondad y virtud del confesor no le obun- / bran ${ }^{230}$ ni le perjudican un punto los males agenos, sino es cómplice ni es causa de los pecados. Esto no me parece necesitar de / probanza, pues no lo ignoran las mugercitas y niños de la / esquela. La mala disposición de los penitentes le aflige â Vuestra Paternidad / como si tubiese la culpa de ella. Buen castigo les espera â los / incrédulos, falsarios y sacrílegos; pero, al confesor que hizo cha- / ritative lo que pudo por ellos, reposita est illi corona justitie $^{231}$, / propter bonum certamen ${ }^{232}$. Vuestra Paternidad no me pregunta para los peniten- / tes, a estos se les dice lo que les toca quando comviene, sino para sí, para su / oficio, para hacerlo bien hecho, sin escrúpulo, sin que en esto tengan / que ver los pecados agenos, si el confesor no coadjuba a ellos ni ama / esos vicios, antes va por lástima y charidad de su próximo a qui- / tarlos. ¿Cómo será reo de lo que no está en su alvedrío? El confesor / no tiene otro remedio que dar aesa perdición más que dos cosas, o / que sean tres, de aquí no puede pasar: la doctrina, el sacramento con / la virtud que ai enél, y quizá algún castigo que convenga en la re- / prehensión y medicina. Y use Vuestra Paternidad bien de esas cosas, y no per- / derá el elogio del euge, serve bone et fideli $^{233}$. En lo demás, si él / no fuese un incrédulo y sacrílego, ia dixe a Vues-

${ }^{228}$ Tiene en la mente aquí el autor el pensamiento agustiniano que reza: "Sed si angustantur vasa carnis, dilatentur spatia caritatis" (Agustín de Hipona, s. 69,1,1, PL 38,440-441).

229 Jn 12,35. Variante: "Adhuc modicum, lumen in vobis est”.

${ }^{230}$ Término portugués que significa 'cubrir de sombra, oscurecer, nublar, eclipsar, ensombrecer'.

${ }^{231} 2$ Tim 4,8. Variante: "In reliquo reposita est mihi corona justitiae".

${ }^{232} 2$ Tim 4,7. Variante: "Bonum Certamen certavi".

${ }^{233}$ Mt 25,21. 
tra Paternidad que todos los sa- $/ /^{40 v}$ mentos, por darse por ministros públicos, están expues- / tos aque los reciban los indignos sin culpa de los que cha- / ritative los franquean.

Dice el Padre Maestro que el Tridentino pone las tres partes / de la confesión, y que ve que no las traen los penitentes. No se / le dice a Vuestra Paternidad que el Tridentino no aia puesto las partes del sacra- / mento y los actos precisos del que confiesa para su fruto, pero no dice / el concilio al confesor que es menester que los vea este, y que no de- / be absolber al reo hasta que vea esos actos por vista como de ojos; / y que si absuelbe sin ver primero, hace un sacrilegio haciendo el / sacramento nulo. No dice esto, antes manda que se faborezca al peni- / tente siempre que la charidad lo mandase. Por esto el sacerdote corre / presuroso al moribundo para apretarle la mano, y si llegó â tiempo / para poder darle la absolución, queda consolado y sin escrúpulo, go- / zoso de que por fin llegó â tiempo. El escrúpulo y desconsuelo / es si, por no darse prisa ô por alguna falta, no le pudo dar la / absolución. Esto es assí / porque la charidad tan mandada obliga / â favorecer al próximo en lo que necesita, y esta a nuestra mano. / Pero en verdad, que entonces no ve ni puede ver los actos del peni- / tente el confesor. Ysin aver visto, lo absuelbe gustoso y sin es- / crúpulo de pecado ni de sacrilegio. Antes muchas veces lo ab- / suelbe, viendo con desconsuelo la indisposición del moribundo, / como si le dio el mal con la concubina al lado, o en penden- / cia y desafío, o es sugeto de mal crédito y de malos hábitos, / o que en su enfermedad no quiso confesar, y lo dilató hasta que / aquel punto instó tan mucho. Y no obstante estas premisas, //4lr nadie niega la absolución â tales, juzgándose con razón / tiranía y falta de charidad y de conmiseración el no aiudar / al próximo en tal estrecho, por si forte le sirviese, no sea / que, si perece, tenga la culpa el sacerdote. Ysi por fin mu- / riese mal, que sea suia la culpa y no falta de Charidad en la / Yglesia, siempre buena madre aun con sus hijos malos. En esto / se ve que puede el confesor obrar bien en dar la absolución / que da por charidad, aunque el penitente no logre fruto por no / tener los actos precisos. Son dos cosas separables: ser el con- / fesor bueno y el penitente malo.

Solamente dos cosas solicita saver el confesor en el mori- / bundo para dar la absolución. La una, que crea la virtud del sacramento, / y esto lo averigua viendo que es cristiano y por eso confiesa en su áni- / mo los sacramentos que quiera, que pida, que deseé; y para que sepa / el confesor qué pide, basta que algún testigo diga que pidió, ô el / moribundo se explique con señas o apuntando la mano / o con una mirada, y otras señas no mui claras; sobre / lo qual save Vuestra Paternidad quánta anchura da la teología, y todo / este cuidado consiste en lo ia dicho ne forte el próximo nece- / site de mi aiuda, y fuera crueldad negarla. Vea aquí Vuestra Paternidad / reducidas a dos cosas 
precisas para que el confesor absuelva ho- / neste et charitative, y por eso sin escrúpulo, quia bene, quia / ordinate. Una es feê del sacramento y la otra es virtud de / esa feê, pedir, desear, querer; y en una palabra venir con / buena y verdadera voluntad, que io llamo buena intención. / Entonces alomenos no ai sacrilegio, ni en uno ni en otro. $/ /^{41 \mathrm{v}}$

Quizá driá mi Padre que el moribundo es otro caso en que / no puede haber escrúpulo en absolber al que pide y desea por las / estrechas circunstancias que no dan treguas para otra cosa; como / ni entonces se atiende ni se aguarda a que la confesión sea / entera. Aque digo que es otro caso, pero es el mismo sacramento. / Este siempre se debe dar con respecto y nunca, nunca, se puede / cometer sacrilegio ninguno, ni por un próximo, ni por la / salbación de todo el mundo. Porque non sunt facienda ma- / la (dice el Apóstol) unde veniat bona $^{234}$. Ni la charidad / manda ni puede mandar lo malo, ni agit perperam ${ }^{235}$. Luego, si se da la absolución al moribundo sin escrúpulo y con / gusto, es porque se sabe que se da sin pecado, sin sacrilegio y / sin falta de reberencia al sacramento. Y pues la Yglesia manda al / Ministro que absuelba, es señal de que se da la absolución ordina- / te, bene et honeste, quia charitative. De adonde se colige / que, quando se da la absolución en otras ocasiones (no tan estrechas), / en que por otras circunstancias, no las mimas, pero por la ne- / cesidad mui parecida, se da, digo, la absolución por charidad, / no ai sacrilegio ni escrúpulo; antes la Yglesia y la Theología man- / dan que se dé al reo miserable que creê, desea y pide lo que es / suio, ne forte le suceda algún daño, el que quizá se ve o se vi- / ene a los ojos, ô ne forte le prive de algún bien oculto que no alcan- / zó en lo que io me hiciera más reo que el otro. Y Vuestra Paternidad mismo, / aese miserable que asquea por lleno de abominaciones, y que / duda absolberlo, / y si lo absuelbe, queda con escrúpulo, porque no ve, dice, en él los actos en el penitente precisos; dese, digo, $/ /{ }^{42 r}$ desechado lo absolviera, desde luego Vuestra Paternidad, si allí le acome- / tiera un mal repentino, y sin ver esos actos entonces, los / que no veía antes, con toda satisfacción y seguridad le diera / promptamente la absolución, Padre mío, ¿quién hizo en Vuestra Paternidad esta / mudanza tan repentina? ¿Qué cosa desató la duda, quitó el es- / crúpulo, sosegó el ánimo? Fixamente no es otra cosa que la cha- / ridad y la obligación de socorrer al próximo, ne forte se pi- / erda por culpa

234 "Non sun facienda mala, ut eveniant bona": "No es lícito hacer una cosa mala porque de ella se pueda derivar una buena". Cf. J. Cantera Ortiz de Urbina, Diccionario Akal del Refranero latino, Akal, Madrid 2005, 154. Se trata de una sentencia muy afianzada en materia jurídica, basada en Rom 3,8: "Et non (sicut blasphemamur, et sicut aiunt quidam nos dicere) faciamus mala ut veniant bona: quorum damnatio justa est" (A. Losada, Juan Ginés de Sepúlveda a través de su Epistolario y nuevos documentos, CSIC, Madrid 1973, 294).

${ }^{235} 1$ Cor 13,4 . 
del ministro, que le niega lo que le pide / aquel recta intencione. Y ¿porqué, pregunto a mi Padre, no / hizo antes la charidad ese oficio? O ¿porqué ella no basta / para el sosiego en otras ocasiones, en que, sino esas mismas, / ai otras necesidades multiplicadas a miles?

Quizá dirá mi Padre que ai diferencia grande, porque / el que cae en peligro de morir se presume que quiere salvar- / se; y de aí se colige que interiormente desea con eficacia la emmi- / enda, y pide sin hablar que se absuelba / con ansia, y el mis- / mo acto de morir pone como a los ojos los actos precisos / para el sacramento, los que no v(e)ía el confesor quando sano, y se v(e) ía / estar frío como un hielo. ¡Ha! ¡Padre mío! Que estos son discur- / sos vagos, esas son ideas y providencias humanas de las que dice / la Escriptura son tímidas e inciertas. La charidad, que omnia / credit, omnia sperat, omnia sustinet $^{236}$, es la que govierna ese / lanze para el acierto, y para quitar el escrúpulo. En lo demás, por / lo natural, si el moribundo quando sano no estaba dispuesto, menos lo estará caído el ánimo en el cuerpo y sepultado en / él con el dolor y la enfermedad. La luz de Dios es la que $/ /^{42 v}$ ha de comenzar la obra, dirigirla y perfeccionarla. Y / cree Vuestra Paternidad esa gracia y mutación soberana sin tener â- / quel alma entendimiento, sepultada de nuebo en las igno- / rancias y tinieblas en las que, si algo percibe, es solamente evi- / tar el daño del cuerpo miserable, que es lo que le aflige. Ya / veo eso, dice Vuestra Paternidad, pero que espera de la gracia y miseri- / cordia que haga la diestra del Excelso esta mudanza. Bien, / pero por fin hemos venido aparar a la charidad sola, / que omnia sperat, omnia credit $^{237}$. Y ¿porqué, pregunto a Vuestra Paternidad, / no espera el que Dios haga esa gracia secreta también / con él quando se confiesa en salud? Ciertamente admira que / la charidad espere lo mui difícil y no espere lo más fá- / cil. La gracia en aquella hora estrecha es milagrosa, y / Dios, que no quiere mortem pec(c)atori s $^{238}$, sino salbarlos a todos, / no suele querer ni salvarlos por caminos milagrosos, / alguna vez lo ha hecho, pero ha dicho que, por lo común, lla- / ma, convida, justifica y salva por el camino ordinario / de la gracia, conque govierna el mundo y al pueblo de los es- / cogidos. Admira, pues, que la charidad espere en el moribundo un milagro que no está prometido, y no espere para el mis- / mo quando sano una gracia ordinaria conque Dios la ama, insta / y solicita por auxilio oportuno en toda la vida, sin aguar- / dar a hacer milagros en lances estrechos. Crea, pues, mi Padre, / que Jesucristo no desamparó su Yglesia con su Ascensión al cie- / lo. Todo lo ve, todo lo govierna, yaun sequedó con nosotros, / y nos acompaña

\footnotetext{
${ }^{236} 1$ Cor 13,7 .

${ }^{237} 1$ Cor 13,7 .

${ }^{238}$ Ez 33,11 .
} 
usque ad consumationem saeculi ${ }^{239}$. Él mismo //43r instituió los sacramentos y ministros para su uso: el está lla- / mando a los malos para hacerlos buenos; forte ese ese malo, / aquien Vuestra Paternidad desecha, es llamado, y Dios dio esa voluntad de / venir de creer, de desear su salbación, de confesar. Por eso / ai más razón de esperar de la divina gracia que el sacramento / le sirba quando confiesa sano, que no la difícil y milagrosa de / quando moribundo en lance estrecho.

$\mathrm{Ni}$ en esto se falta al Tridentino, porque siempre / es verdad que ad perfectam et integram remisionem pec(c)a- / torum son precisas las tres partes del sacramento: confesión, / contrición y satisfacción. Pero, hablando de la que da más / cuidado, que es la contrición, ¿cómo se ha de conocer ni pal- / par? Muchos mostruos se cometieran en el manejo del / sacramento si este se diera â juicio vago de los ministros, sino / se administrara â nadie hasta que ala ignorancia de nuestra / capacidad endeble y falible constara, juzgara (oliera, como Vuestra Paternidad / dize) el dolor, el temor y disposición. ¡Ô! ¿Qué ierros se cometie- / ran si, a juicio privado de cada uno (oliendo unos, y otros / no oliendo en tan infinitos casos) $)^{240}$, se había de conferir la / absolución? Los dictámenes de los hombres son diferentes, / y sobre una misma seña ai mil dudas. Cada día nos enga- / ña el sentido aun en lo corpóreo. Ni se juzga seguro cre- / er ${ }^{241}$ para el recto juicio, ¿quánto menos lo será para lo espiritual del / camino? ¿Cómo había el concilio, ni Dios mismo, de man- / dar una cosa imposible? El corazón del hombre es ines- / crutable, dice el profeta: Cor hominis inescrutabile, et quis //43v cognoscet illud? ${ }^{242}$, y responde que solo Dios, qui scrutatur re- / nes, et corda ${ }^{243}$. ¿Ni qué seguridad tubiera nunca el confesor / del que obraba bien, si para esto tubiera obligación de asegurarse / de la contrición del penitente? Ciertamente la regla de las / operaciones debe ser firme y estable para ver por ella si peca / o juste obra, según se acerca o se aparta el hombre de la re- / gla; y como nunca se puede con certeza sondear el ánimo, / i menos ingenios cerrados, broncos e indóciles, siempre / estubiera el de el confesor inquieto, si tubiese obligación / en este punto a indagarlo todo. Con esto no hubiera ministros / que se expusieran al trabajo, huiendo todos de la confesión / como de una espada afilada que lastimaba sus concien- / cias,

\section{${ }^{239}$ Mt 28,20.}

${ }^{240}$ Llamada de atención para evitar arbitrariedades y disparidad de opiniones, que puedan confundir a quienes se van a confesar.

${ }^{241}$ Opto por este término ('cre- er:') como el más seguro para entender el pensamiento del autor, ya que en el texto original parece escribir 'creteri', que no halla sentido en el contexto.

${ }^{242}$ Jer 17,9. Variante: "Pravum est cor ómnium, et inscrutabile: quis cognoscet illud?".

${ }^{243} \mathrm{Sal}$ 7,10; Ap 2,23: "Scrutans corda et renes, Deus". 
no pudiendo cumplir lo que se les mandaba, como a / Vuestra Paternidad le sucede, por querer oler el dolor de lo que juzga tiene / obligación, como buen juez para rectamente sentenciar. Pero / no ve Vuestra Paternidad que no puede ser, y que fuera preciso que Dios y / la Yglesia pusieran por ministros a los Ángeles, excluidos / los hombres de lo que no pueden.

Ciertamente, si aun el hombre sabe de sí mismo lo que / pasa en su ánimo, ¿quántas veces ignora si tiene dolor? Quiere, y aun duda de su voluntad. Resiste y cree que consiente. / Consiente en bueno o en malo, y no lo advierte. Juzga que / ama lo que aborrece, y le parece que aborrece lo que ama. Y / guerra el confesor entrar en ese chaos sin suelo para ase- / guarse de lo que pasa, y el ánimo obra, quando el que está aden- / tro duda y no penetra. Quod operor, non inteligo ${ }^{244}$, decía $/ /^{44 \mathrm{r}}$ san Pablo, y (c.) 9 v. 11 (de) Job, tan avisado, decía hablando de la / incomprehensibilidad de Dios: Si venerit ad me non vi-/ debo eum, si abierit non intellligam ${ }^{245}$. Y Vuestra Paternidad quiere / entender el Dios que ai en aquel alma suia, y si la ha vi- / sitado dándole temor santo, porque sino veo, huelo, pal- / po ese Spíritu Santo, quedo con escrúpulo y sin consuelo. No se / fíe vuestra Paternidad de esos signos falibles, que engañan â veces. A mí / me ha sucedido muchas, y aun muchísimas veces, cre- / er según lo que aparecía en lo exterior, que el penitente es- / taba frío y, como dice Vuestra Paternidad, como un ielo; y, de repente, / quando no se esperaba, ni de adónde nuestra corta vista podía / sospechar se escondía tal perla de la gracia, salir afuera / un fuego sagrado de ôlor vehemente con estremos mui / sensibles. ¡Reflexione ahora mi Padre si io, porque no palpava / ni olía la mudanza que traía ese penitente, lo hubiera de- / sechado como juez recto, governado por mi mal juicio / que ierro! ¿Que monstruo! ¡Qué desacierto no hubiera cometido! / Y quizá quedara vanaglorioso de haber sido confesor / mui ajustado a las reglas del Tridentino. Estos casos / que he experimentado son muchos, de adonde se ve que / en muchísimos más ai en que esperar aia en el ánimo / esa buena voluntad que deseamos, aunque en lo que vemos / aparezcan fríos e indispuestos. No es, pues, nuestro senti- / do y juicio falible la regla que Dios nos dexó para ministrar / los sacramentos. Ni es preciso ni obligación el estar seguros y ci- / ertos de la disposición y actos del reo. Porque antes quiere Dios $/ /^{44 v}$ que vibamos en feê. Y por feê y esperanza, â ciegas / nos lleba de la mano para que no erremos. No busque Vuestra Paternidad / ver ni palpar, porque beati qui non viderunt et credide$r_{u n t} t^{246}$. / El medio de caminar en feê obscura no ha dexado para el / acierto,

\footnotetext{
${ }^{244} \operatorname{Rom} 7,15$.

${ }^{245}$ Job 9,11 .

${ }^{246}$ Jn 20,29.
} 
y obrar sin escrúpulo, sino es la prudencia, jus- / ticia, fortaleza y templanza. Estas nos dirigen y en- / señan como regla firme de nuestras operaciones, no el sen- / tido y juicio falible de cada uno imprudente, vago y / a veces injusto, enfermo y destemplado.

\section{Regla IX}

Aún quisiera mi Padre Maestro una regla fixa para / saber quándo se daría el sacramento charitative para darlo / honeste y sin escrúpulo, porque se da ordinate. El dar / charitative consiste en el amor. El amar al próximo es / desear que se salbe, alegrándose de sus bienes, que condu- / cen asu salbación, y sintiendo los males que le estorban / conseguirla. Esto es diligere, a que se añade el orare ô / benefacere, si es verdadero el diligere, porque el que desea mu- / cho la salud del próximo la pide â Dios instanter como ora / por sí mismo. Assí pone de su parte para ese mismo efecto / lo que está a su mano, que es el benefacere al otro, según / está mandado: Diligite, orate, benefacite ${ }^{247}$ aun a los mal- / los que os persiguen, manda el salbador, y no abrá mal / ninguno en obedecerlo. El confesor tiene asu mano / el sacramento como juez a quien sele ha cometido ab- / solber y perdonar pecados; y, si como juez árbitro de $/ / 45 \mathrm{r}$ esta causa, en vista de todo juzga que al penitente se / le hace bien y que le combiene para ese fin de la salbación / darle el sacramento, y más si ve que el negarlo le servirá de / estorbo, entonces dando la absolución hac intentione, da / el sacramento charitative et ordinate, honeste, et bene, / et ideo laudabiliter. Esto está claro, dice Vuestra Paternidad; pero como / le puede servir el sacramento al indigno para su salvación; / antes le servirá para ser más presto condenado por sacrílego. Es / así que es indigno el que no trae los actos precisos que pone el Tri- / dentino. De que se colige debe el confesor, como juez, indagar si / el reo trae esos actos para juzgar si es o no digno, no sea que, / porquerer hacerle bien, le haga mal, con lo que no dará el / sacramento charitative, y siempre quedará su ánimo con es- / crúpulo, enrredado con tales cuidados, sin tener regla se- / gura para evadirlos y administrar el oficio con paz, utilidad / y sosiego. Aloque digo â Vuestra Paternidad que confunde lo falso con lo ver- / dadero, y de aí le biene el escrúpulo, aun quando está el sa- / cramento bien y charitative dado por parte del ministro. / Es cierto, y mucha verdad, que no se le puede dar al indigno / como tal, que el sacramento indignamente o sacrilege recibido / no le serbirá al incrédulo para ser salbo.

${ }^{247}$ Cf. Mt 5,44. A este axioma lo denomina Francisco Ortiz Lucio "el blasón de los cristianos" (Jardín de amores, santos, y lugares comunes, doctrinales y pulpitales, Juan Íñiguez de Liquerica, Alcalá de Henares 1589, tratado 7, capítulo III, 81v.). 
También es verdad / que, sino lleba nada de los actos que prescribe el Tridentino / al penitente como partes del sacramento, no sacará este nada / para su bien, y mucho para su condenación. Assí mismo es / cierto que el confesor, como juez interior de aquella causa, / debe indagarla e imponerse bien en ella para sentenciar- $/ /{ }^{45 v}$ la afabor ô del reo, absolviéndolo, o de la ley vindicativa, / condenándolo. Esto nadie lo niega, ¿ni quién ha de ne- / gar verdades tan claras? Pero Vuestra Paternidad mescla muchas cosas / falsas, poniéndole al confesor muchas obligaciones que / no tiene para enredarse y amargarse con escrúpulos y cuidados / agenos.

Es assí que no se le puede dar el sacramento al indigno. Pero / como a tal o como conocido que es ciertamente indigno. Mas le / pregunto a Vuestra Paternidad: ¿Tendrá obligación el confesor a indagar la ver- / dad cierta del caso, cosa imposible asu ministerio? Es ver- / dad que es juez; pero no juez divino y angélico, sino juez hu- / mano. Es juez del interior, pero por allegatos e informa- / ción del reo mismo. Es juez de causa interior; pero nun- / ca puede llegar a las secretas interioridades, adonde solo en- / tra el Juez que corda scrutatur et renes ${ }^{248}$. Es juez, pero ju- / ez de comisión, y cumple con arreglarse a lo que se le comete. / Es juez, pero no de juicio ultimado y definitibo, que Dios / ha reserbado para sí en el día último. Es juez, pero del / tribunal ideado de la misericordia â fabor del reo, para que este salga libre del terrífico que nos aguarda â todos. Es / juez, pero de lo que puede, y no deloque le es imposible. Y ¿qué / puede? Puede indagar dos cosas, y eso le basta, para que, asegu- / rado de ellas, la charidad haga su oficio, que es hacer bien / al próximo. Una es que crea la virtud del sacramento para labar / sus pecados, que Cristo mereció por su cruz, y mana como fu- / ente de aguas vivas para los que las piden, las desean y emmi- $/ /^{46 r}$ endan los pecados de que quieren ser limpios. La otra es que, / en virtud de esa feê, lleguen a pedir el sacramento con volun- / tad verdadera y sincero ánimo. Ambas cosas se requie- / ren también para administrar otros sacramentos, esto es: cre- / er y querer recebirlos. El ministro no indaga si quiere / recibirlos con voluntad verdadera o fingida; cree caritative / que veri et non ficte pide, i desea, y porque lo dice con la boca / se los franquea. Pero en el de la penitencia es más que mi- / nistro; es juez, y debe juzgar de esa voluntad, e indagar si / es verdadera o es fingida, y no basta que el penitente lo diga / para que lo crea. Deve asegurarse quanto pudiese (y no más) de que / pide y desea el sacramento vere et non ficte, sincere et non / dolose, para poder darlo charitative.

Del mismo modo debe indagar los actos precisos / del sacramento según los señala el Tridentino. Porque, según / fuese la voluntad ô el querer el sacra-

${ }^{248}$ Sal 7,10; Ap 2,23. 
mento más o menos verda- / dera y sincera, tendrá el penitente más o menos de los / actos mandados, y se acerca más o menos al fruto pleno, / que es la justificación y la entera y perfecta remisión de / los pecados; porque enquerer vere et non ficte esta cierta / la recta intención. Este es el primer paso que da el ánimo / que amó lo malo, amando ia lo bueno. $\operatorname{Pr}(a)$ eparatur voluntas / a Domino $^{249}$. La prepara por la feê que Dios excita con la gracia / auxiliante. Así lo cree la charidad aun en el más malo: / Quia charitatis omnia credit, omnia sperat $^{250}$. No desconfía / de la conversión del perdido. Esta ha de comenzar alguna $/{ }^{46 v}$ vez si ia no lo juzga con temeridad réprobo, y quiero se- / gregar ia sin tiempo, y sin ser de mi oficio ni empleo, la zi- / zaña del grano con orgullo presuntuoso, sin pabor al Jui- / cio divino. La charidad que espera esa conversión cree que / es ia quizás oy quando ve la buena voluntad con que quiere lo / bueno y no quiere ia lo malo. Está su ánimo mudado de / uno â otro. No quiere el pecado, busca para labarlo el sacramento, / se convierte de un estado â otro, seguía antes su voluntad / los vicios y a los mundanos y ia quiere las virtudes, y sigue / a los sacerdotes para que lo enseñen, lo dirijan in viam salutis ae- / ternae $e^{251}$. Con esta recta intención y voluntad, pide absolución / y penitencia. El juez que indagó lo que pudo esa voluntad / ve en ella los actos del penitente, aunque no sea más que / principiados, y da gracias a la misericordia divina, que / mudó la mala voluntad en buena, y espera que continua- / rá la obra; y, sin meterse en lo más secreto del ánimo / que no lo toca, ni puede saver lo que en aquel centro obra la / gracia, abriga quanto puede aquella voluntad, aquel querer, aque- / lla conversión, aquel initio que ha juzgado en vista de todo, y no / niega ael penitente lo que vere et sine dolo pide y desea, dándole / el sacramento para su remedio y salbación, por lo que lo da chari- / tatiba, pues en negarlo entonces obrará tiranice.

Esto también está claro, dice mi Padre Maestro. Pero, como es / fácil que el malo quiera ser bueno, y es mui común esa vo- / luntad en quasi todos, y la contrición que pone precisa el Tri- / dentino es difícil, siendo los motivos sobrenaturales, se ve $/ /^{47 \mathrm{r}}$ el poco fruto, aun después de dada charitative la absolución. / Por ver esa voluntad ser buena; y después de haver creído, / y muchas veces atantos, buelben y viven perdidos y sin freno. / Este es el desconsuelo que no se le quitará â Vuestra Paternidad con regla / ninguna para sosegar el ánimo confesando sin escrúpulo. / Padre mío, io también sospecho

${ }^{249}$ Prov 8,35 (LXX). Véase lo dicho en la nota 202.

${ }^{250} 1$ Cor 13,7 .

${ }^{251}$ Agustín de Hipona, ciu. Dei 19,23,3, PL 41,652. Petición habitual presente en las oraciones (v.gr., cf. Acta ecclesiae mediolanensis a Sancto Carolo Borromaeo, II, Paulo Pagnonio, Mediolani 1846, 1159). 
que este escrito aprovechará â / Vuestra Paternidad mui poco, y eso no quita el que tome charitative este tra- / vajo, a lo menos para mí fructuoso, con esperanza de que forte / a Vuestra Paternidad le sirba de algo. Mi Padre quisiera que todas las conversio- / nes fuesen extraordinarias como la de la Magdalena, de / Zacheo y san Mateo, la Samaritana y el Publicano. Y / también encuentro io a veces, y no pocas, conversiones mi- / lagrosas con goso y admiración de mi alma. Dios dispuso / el govierno del mundo de ese modo ordinario, y ordenó la / práctica del sacramento con el que va disponiendo su obra in / aquis multis, caminando por cima de las aguas, sinque se / conosca su huella, et semite tuae non cognoscentur ${ }^{252}$. $\mathrm{Al} /$ confesor no le toca entrar en ese mar en que perderá el / pie; solamente le toca en su recinto, con la dirección de la / prudencia, obrar con intención charitativa el ministerio / siempre para bien y salbación del próximo.

El desconsuelo es preciso, pero no el escrúpulo. La cha- / ridad que non

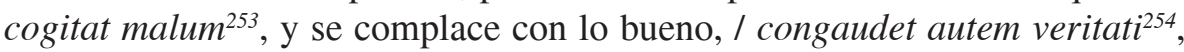
quando ve los males de los malos se afli- / ge, se entristece, se desconsuela, pero no se irrita, charitas non irritatur ${ }^{255}$, patiens est, venigna est $t^{256}$. Siente las terqueda- $/ / 47 \mathrm{v}$ des de los incrédulos, pero omnia sustinet ${ }^{257}$ in spe. No se le / quite â Vuestra Paternidad el desconsuelo de tratar tantos malos, sino que / los trate para su remedio, y (en) esto no ai escrúpulo, siendo el / bien proprio y los males son agenos. Siempre los buenos / pastores se han afligido de la incorrigibilidad de los malos. / El Psalmista dice: Vidi pr(a)evaricantes et tabescecebam, quia man- / data tua non custodierunt ${ }^{258}$. Vea Vuestra Paternidad en las cartas de san / Pablo sus aflicciones y llantos sobre la pérdida de sus discípulos, / por lo que había travajado; quánto se lamenta de las disensio- / nes de los de Corintho, de la perversión de los Gallatas por / el engaño de los pseudo-apóstoles, igeneralmente quis infirma- / tur, decía, et ego non

${ }^{252}$ Sal 76,20. Variante: "In mari via tua, et semitae tuae in aquis multis, et vestigia tua non cognoscentur".

${ }^{253} 1$ Cor 13,5 .

${ }^{254} 1$ Cor 13,6 .

2551 Cor 13,5 .

${ }^{256} 1$ Cor 13,4 .

${ }^{257} 1$ Cor 13,7 .

${ }^{258}$ Sal 118,158. Variante: En lugar de "mandata tua", aparece "eloquia tua", empleándose la primera expresión en los versículos 4, 40, 45, 69, 86, 87, 100, 119, 128, 131, 134, 146, 159, 166, $172,173,176 \ldots$ 
infirmor? Quis scandalizatur, et ego / non uror? ${ }^{259}$. Lea Vuestra Paternidad lo que san Agustín se lamenta sobre los males / que no podía remediar con su continua predicación, solicitud / y afán; pero sin dexar por eso el trabaxo, sin desechar a los / perdidos como quisieran ser buenos. Y los Profetas en la / Escriptura quánto se afligían por la incredulidad de los tercos, / y no los dexaban hasta que por el caso perdían la vida. Vea Vuestra Paternidad / singularmente en Geremías, en su predicación tan llena de contra- / dicciones antes de la captividad; pero el maior asombro fue / después, con el pueblo residuo. Este, indócil contra su consejo / y contra el mandato de Dios de que no saliese de Judea para / ampararse del Aegipcio contra el Babilonio; y sin hacer / caso de la amenaza de Dios que llebaría â Aegipto la espada / de Nabuco, no obstante, tercos, se refugiaron a la sombra / del Aegipcio. Y Geremías, ¿qué hizo conesta obstinación? ¿Los //48r desamparó? ¿Los abandonó? Irritando la charidad, ¿perdió / la esperanza y la subsistencia? Los siguió, les asistió, les pre- / dicó, los mantubo, para que no se diesen a los ídolos del país, para / templar â Dios, no viniesen sobre ellos los males amena- / zados. Poco fruto sacó de los malos; antes estos ingratos / â tanto beneficio lo apedrearon; pero el profeta murió / cargado de palmas por la charidad victoriosa en tan / charitativas hazañas ${ }^{260}$.

Dice Vuestra Paternidad ve poco fruto de dar mucho el sacra- / mento; pues io veo mucho, y ciertamente se mantiene la / Yglesia con la frequencia del sacramento, y el de la communión, / y vemos que está más bien governada con esta frequencia que / no la Yglesia antigua en que no se frequentaba. Por es- / ta experiencia los confesores mandan como medi- / cina saludable la frequencia del sacramento, y vemos / en los que se confiesan con amenudo estar más continen- / tes, más freno, más cuidado con sus conciencias. / La Yglesia manda a todos que lo reciban saltem una vez / al año, y quisiera que fuese amenudo. Luego es se- / ñal de que hace provecho. Y sino lo hiciera sino auno, / quizá entre veinte como Vuestra Paternidad dice para tanto daño y per/ juicio, no hubiera el Spíritu Santo instituido el uso, ni hubi- / era inspirado a la Yglesia tal práctica. Veo, pues, io mucho / fruto, y a los malos se les hace mucho bien y fabor en / medio de tanto mal. Y si son malos, es porque no per- / severan, y vemos que son más malos mientras más //48v se retiran del sacramento. No perseveran en la buena / voluntad, que Dios les dio, y no porque el sacramento les hi- / zo mal como lo recibieran con buena voluntad y rec- / ta intención. No crea Vuestra Paternidad que llegarse el pecador a / Cristo ô a

\section{${ }^{259} 2$ Cor 11,29 .}

${ }^{260}$ Para un acercamiento rápido a la vida, actividad y mensaje de este profeta, cf. J. L. Sicre, Profetismo en Israel, Verbo divino, Estella 1992, 308-319, 470-474; P. Jaramillo, "Jeremías. Historia, vida y mensaje": Reseña bíblica 37 (2003) 5-14. 
la cruz, fuente de todas las gracias (cuia virtud está / en el sacramento oculta) con feê y recta intención, con espe- / ranza del perdón y con buena voluntad, será sin fruto nin- / guno, ni el salbador lo dexará vacío sin darle alguna li- / mosna, como lo hacía a quantos ael bona intentione se le lle- / gaban: Quia virtus de illo exibat, et sanabat omnes ${ }^{261}$. Es / verdad que ban con muchos pecados, pero no ban pecan- / do, no ban sin feê, ô con mala intención, o con dolosa / fingida voluntad. Esso fuera ir pecando.

Pero ¿qué fruto, dice Vuestra Paternidad, pueden sacar si, v. gr., no / lleban contrición, y lo más que lleban es un initio de ella / en la voluntad buena, que Dios les inspira para que cresca / si continúan, si caminan, si se aiudan, si perseveran / en la vida nueba prometida? ¿Y más siendo la con- / trición el más preciso acto del sacramento que pone el Tri- / dentino? Que digo dos cosas. La primera, que, llebando feê / del sacramento y verdadera voluntad de recibirlo, en am- /bas cosas se encierra la conversión â Dios, que es la con- / trición; pero quánta sea, y si es la que combiene para la justifica- / ción del reo, lo ignoramos, y es cosa reservada al Juicio / de Dios, y no pertenece al nuestro falible humano, y por / eso incierta. En la feê y en la verdadera voluntad $/ / /^{49 r}$ está encerrado todo loque deseamos en los convertidos, / contritos y dignos del sacramento; ital pudiera ser la feê, que / por ella se les perdonaran los pecados, y tal podía ser la / buena voluntad que se les podía aplicar el remi( $t$ ) tuntur ei pec- / cata multa, quoaniam dilexit multum ${ }^{262}$. Y lo del paralítico: $U t$ vi- / dit Iesus fidem illorum (de los que per regulas lo collocaron ante illum) ${ }^{263}$, dixit paralitico: Remit(t)untur tibi pec(c)ata tua ${ }^{264}$. De adon- / de se ve que en la fee y buena voluntad se encierra todo, / más o menos, lo que pide el Tridentino para el fruto pleno / del sacramento. Luego en indagando el confesor esta verdad, / y estando en lo que ha podido seguro de su voluntad no fin- / gida, sino verdadera, hace (en lo que le toca, y puede) lo que / basta para dar el sacramento charitative en provecho del pró- / ximo. Todo se encierra, dixe, pero en general; en lo / particular de quán verdadera es su voluntad, lo ignora- / mos, ni quánta sea su conversión sabemos; por lo que solo / abanza el confesor a asegurarse de que viene el penitente / con recta intención, buen deseo, buen ánimo, verdadera / voluntad. Ysi le parece que no la trae, procura que nazca / en él (aquel día, y en aquella hora) con las exortaciones / que combiniesen, y como el hombre es mui mudable, ay / esperanza que se mude con lo que se

\footnotetext{
${ }^{261} \operatorname{Lc} 6,19$.

${ }^{262} \operatorname{Lc} 7,47$.

${ }^{263}$ Interesante exégesis, porque remite la fe solo a los camilleros.

${ }^{264} \mathrm{Mt}$ 9,2. Contexto: "Et videns Jesus fidem illorum, dixit paralytico: Confide, fili, remittuntur
} tibi peccata tua". 
le dize. Pero a veces suce- / de que ni aun después de indagar esa voluntad, por / muchos medios, no se asegura dela voluntad since- / ra que se solicita. Y entonces, dice mi Padre, ¿quid faciendum? Digo que se obre prudenter sin escrúpulo. ¿Y qué dicta la $/ /^{49 v}$ prudencia? El que, si se ve que el dilatar la absolución por / modo de castigo y de freno le servirá algo, será charidad / el refrenar y castigar al duro y terco. Pero, si se ve que, por / la rusticidad e ignorancia del reo y por otras cosas que / nos enseña la experiencia, ese castigo es inútil, y aun / dañoso, se le da la absolución prudenter por si forte. Yo / me engaño en mi apocado juicio, y quizá en aquella / dureza y bronquedad (que es de condición suia igenio nati- / bo) se oculta alguna gracia que io ignoro, como en bastan- / tes ocasiones he experimentado. Se le creê lo que dice, / no solo porque lo dice, sino porque no ai fundamento gran- / de para presumir que miente. Es christiano, y fuera / temeridad hacer juicio de que habla con dolo sin po- / der provarlo. Porque nemo presumitur malus nisi / provetur ${ }^{265}$.

Se da pues el sacramento entonces, como se dan los ô- / tros de vibos. En estos está tan puesta por el Tridentino / la previa disposición de estar en gracia el que los recibe y / ministra, como está la contrición puesta para el de la peni/ tencia; y, no obstante, el ministro da los sacramentos, v. gr., / la communión, con solo pedírsela, sin indagar si está / engracia. Y ¿porqué es esto? Porque cree que estará dispues- / to, pues que pide non ficte, sed vere. Al confesor ia dixe / que le toca más porque debe, como juez, examinar esa / voluntad, si es verdadera o es fingida, si es la intenci- / ón recta o viciosa. Pero, si hecho el examen de todo $/ /{ }^{50}$ el conjunto, no se puede tener señas visibles y sensibles / de su verdadera confesión, más también (que) no ai funda- / mento para creer lo contrario, es prudencia y charidad / la que omnia credit, omnia sperat ${ }^{266}$, creer que no miente / un cristiano y en tal tiempo. Con esta misma charidad se / le absuelbe, dándole lo que pide, como enotros sacramentos / los da que piden vere el ministro, porque no le toca más / en su ministerio que dar como ministro público el sa- / cramento instituido para los cristianos que creên, y quando piden, y por eso / lo dan bene, quia charitative. Lo mismo sucede en el de la / penitencia, supuesto el examen de la causa en lo que única- / mente al confesor le toca: dar la absolución bene et charitati- / ve al que le pide vere con voluntad sincera, porque, de negarlo, / no se espera bien ninguno ni fruto bueno alguno para el / próximo, y quizá daño grandísimo y daños muchos que / cada día experimentamos. Pero, de darla con la precapción / de que no dañe

${ }^{265}$ Clásico aforismo jurídico. "Por el hecho de ser excepción el crimen y la maldad, por lo cual es necesario una prueba convincente para que uno sea tenido por delincuente. Nadie se presume malo si no se prueba" (N. Bustamante Bustamante, Locuciones latinas en materia jurídica, Palibro, Bloomington 2012, 284).

${ }^{266} 1$ Cor 13,7 . 
la nuestra misericordia, no ai daño ningu- / no al penitente ni al sacramento, porque se da ordinate et ho- / neste in utilitatem ${ }^{267}$. Y, por otro lado, se espera mucho bien, y / quizá más fruto, en el juicio secreto de su ánimo y el de / Dios misericordioso con aquel mísero, que lo que nosotros apo- / cadamente juzgamos. Y ¿cómo será malo el obrar con pru- / dencia? Esta dicta que es mexor hacer una cosa de que nada / malo resulta, y aun se espera que forte resulte en bien / mui grande que omitirla, de cuia omisión no se espera / ningún bien, sino mucho mal. //50v

Por esto se da sin escrúpulo la absolución al moribun- / do, porque, de no darla, nada se espera bueno para aquel cristiano, / y de darla se espera mucho, y no menos que forte la salvación / dependa de aquella obra charitativa. Se le da con solo / saver que creê y pide, que es el initio alomenos de la contrici- / ón, y en lo demás se dexa â Dios, y se le absuelbe, por si forte / es contrito y digno, desuerte que, si coram Deo no fuese / digno, tenga él la culpa y pague la pena; pero no el mi- / nistro, que hizo charitative lo que pudo, y por eso bene et lau- / dabiliter con premio y sin escrúpulo. Aplique Vuestra Paternidad esta doc- / trina â otros que, si no son moribundos en el cuerpo, lo son, y / aun muertos en el ánimo, por fríos, elados, hediondos, qua- / triduanos; pero ia comienzan a vivir, deseando salir de / el sepulcro, con buen deseo de que vuestra Paternidad les dé la mano, y / no pecará contra charidad el darla por si forte le sirvie- / se siendo un caso, servatis servandis uno mismo que otro, / tocante al escrúpulo que nace de si tiene contrición o no / la tiene, como el Tridentino la pone como parte. / Pero no manda que no se absuelva a nadie hasta que la contrición / aparezca claramente, porque eso es imposible, e hiciera el sa- / cramento impracticable, y menos quando se recibe oi tan fre- / quentemente, se manda a todo el pueblo Cristiano que cada año se / reciba alomenos, so pena de terrible público castigo. Y he- / mos de creer que manda por otro lado la Yglesia misma a los / confesores que, aunque vengan los fieles, no los reciban, que no los / absuelba sino traen señas claras; que los ministros los casti//51r guen, si obedecen, no absolviéndolos; y los ministros los / descomulguen, porque no obedecen. No crea Vuestra Paternidad que manda / la Yglesia cosas contrarias. No ignora que la conversión â Dios / que le conbenía no puede ser de todos, sabiendo quánta mala / semilla ai mesclada con la buena; pero espera de la obediencia / al mandato algún initio bueno, y que, de juntarse con los / sacerdotes, sal de la tierra, con sus exortaciones se remedi- / aran algo las almas y sacaran más provecho confesan- / do cada año, que si por descuido y negligencia pasaran / pecando años enteros.

\footnotetext{
${ }^{267}$ Un borrón dificulta la correcta lectura de esta última palabra; pero lo más plausible es que el autor diga "utilitatem".
} 
Hace, pues, bien el confesor en aiudar a los mise- / rables en lo que puede. Es charidad dar al que pide con ánimo / sincero el Patrimonio de Jesucristo. El Padre bueno de la pará- / bola dio a su hijo menor su herencia, porque la pidió y le / tocaba, da mihi portionem sustantiae, quae me contingit ${ }^{268}$. Fue / culpa del mozuelo el dexar la casa de su padre gastando el ca- / udal luxuriose. No fue culpa del buen padre darle la heren- / cia. Fue justicia, porque le pertenecía; y si alguno murmurara o lo culpase, podía decirle: Oculus tuus nequiam est, nam (quia) ego bonus sum ${ }^{269}$. Bueno es, por lo mismo, darle al penitente la / absolución que pide, patrimonio que Cristo le ganó en la cruz, / y dexó a los ministros como administradores que lo repartiesen a / los que lo piden vere, se les da y bien dado. Pero el penitente se / huie, se va con amigos, dexó la Yglesia casa de su Padre, dexó los sa- / cramentos, olvida los consejos y vive luxuriose, perdiendo todo / con los amigos mundanos; y ipor eso dirá alguno que hizo mal $/ /^{51 \mathrm{v}}$ el confesor en absolverlo, en darle el Patrimonio que le toca como / cristano? Dígale Vuestra Paternidad al que en su ánimo le acusase con escrúpu- / lo, oculos tuus nequam est, nam (quia) ego bonus sum. Y si rever- / sus ad se, el pecador concibe buena voluntad a su Padre, / surgam, et ibo ad Patrem meum ${ }^{270}$, confesando sus abominacio- / nes, reciba Vuestra Paternidad esa voluntad nueba y buena por si forte nace / adentro del auxilio divino que le hizo volber en sí, yassí, y venir, / reversus ad se, ibo ad Patrem meum, et dicam $e^{i 21}$.

La otra cosa que digo â Vuestra Paternidad sobre su escrúpulo es que no es / cierto ser el fruto del sacramento indibisible, por lo que puede el / que lo ba apedir y lo desea consincera voluntad sacar algu- / na parte de fruto, con solo el inicio que vemos, sin ver aún en / él que venga contrito. El Santo Concilio pone por parte del sacra- / mento la contrición; pero añade que es parte precisa ad integram et / perfectam remis(s)ionem pec(c)atorum ${ }^{272}$. De aquí se colige que puede haber / quizá otra, y otras partes enque, porque se remitan en algo los peca- / dos sin llegar a la justificación ni a la infusión de la gracia, / que hace hijos de Dios, en lo que consiste la entera y perfecta / remisión de los pecados, y aun no se cree entera y perfecta / la remisión hasta que se condona toda la pena. De aí es que / añade el Concilio por parte del sacramento la satisfacción de la pe- / na que se cree aún resta, perdonada la culpa, aun por in- /

${ }^{268}$ Lc 15,12 .

${ }^{269}$ Mt 20,15.

${ }^{270}$ Lc 15,18 .

${ }^{271}$ Lc 15,18 .

${ }^{272}$ Concilio de Trento, Sesión XIV, c. 4: I. López de Ayala, El sacrosanto y ecuménico... 170 (DH 1704). 
fusión dela gracia que justifica. De aquí es el cuidado de / los confesores en imponer penitencias, y el de la Yglesia en / conceder indulgencias por misericordia. Y ¿porqué es esto? Por / que aún no se juzga perdonada enteramente la culpa mien- $/ /^{22 r}$ tras resta el reato de pagar la pena temporal merecida, / aunque no sea eterna. Tiene, pues, partes ino es indivisi- / ble el fruto del sacramento. $\mathrm{Ni}$ ¿quién podrá atar las manos / tornatiles plenas hiacinti ${ }^{273} \mathrm{del}$ que en los sacramentos depositó / los thesoros de su muerte, y los joieles ${ }^{274}$ que se formaron de su / derramada sangre, gotas como perlas preciosas, para enrrique- / zer a los creientes, según con más o menos feê los recibiesen, / y se llegasen? Norabuena que sea precisa la contrición para la / justificación, y para vestirse el pecador dela gala dela gracia, y / recibir stolam primam ${ }^{275}$. Pero ¿puede recibir otros frutos sin / estar aún contrito, con sola la buena intención y verdadera / voluntad con que se ampara del salvador, y se acoge ala / fuente perenne de su cruz quien se llegó aél con feê y / voluntad (sea grande ô pequeña), y fue desechado sin darle / de gracia alguna limosna? Nicodemus, v. gr., con poca feê /y sin contrición, que sepamos, antes con la soverbia de Phari- / seo, porque se humilló a Cristo y vino aél con deseo santo, y de no- / che por no ser conocido, el salbador lo recibió, lo enseñó, lo / adaptó, para que después se justificara amando, y en medio de el / día, sin miedo, se declaró discípulo del crucificado; y por aque- / lla vis(i)ta medrosa y apocada, fue luego escogido para servirse / de él en su sepulcro, y aun coronarlo con el laurel de el / martirio ${ }^{276}$. Tantos frutos consumados nacieron de aquel / initio pequeño.

Ni aún ai seguridad de la contrición para el ple- / no fruto del sacramento. Porque se duda si ha de ser contri- ///52v ción perfecta que justifica. Ya dixe antes a Vuestra Paternidad que era común / sentir de los Theólogos y Padres antes del Tridentino que era / disposición precisa para el sacramento de la penitencia que el peni- / tente llegase justificado ô engracia a la sacramental piscina; / y no obstante el Concilio se contenta con contrición im- / perfecta, que llaman atrición sobrenatural. Esta no justifica, / pero dispone al ánimo así contrito, para que este dé la gracia / justificante que diera la contrición perfecta si ad esset; de / adonde vino el como adagio tan sabido que, con el sacramento,

${ }^{273}$ Ct 5,14. Variante: "Manus illius tornátiles, aureae, plenae hyacinthis".

${ }^{274}$ Joyel: Joya pequeña (cf. https://dle.rae.es/joyel?m=30_2).

${ }^{275} \mathrm{Lc} 15,22$.

${ }^{276}$ Cf. Jn 3,1-21; 7,50-52; 19,39. Sobre la tradición de su martirio, el hallazgo de su tumbra en el s. V, junto con las de Esteban, Gamaliel y Abibo, y el apócrifo Evangelio de Nicodemo, cf. "Nicodemo de Jerusalén": L. Goosen, De Andrés a Zaqueo. Temas del Nuevo Testamento y la literatura apócrifa en la religión y las artes, Akal, Madrid 2008, 248-250; "Nicodemo": A. Ropero Berzosa (ed.), Gran diccionario enciclopédico de la Biblia, Clie, Barcelona 2013. 
/ ex atrit(t)o pec(c)atore, fit contritus vel justificatus ${ }^{277}$. Con esto ia / generalmente los theólogos y los confesores no aguardan a ver / contrición perfecta en los penitentes para esperar fruto / pleno en la justificación del tiempo. Esta anchura na- / ce de creer mucho del sacramento más que los antiguos theólo- / gos, y aun ahora ai algunos cathólicos, y que estubieron pre- / sentes a la definición del concilio, que se mantienen firmes / en la antigua theología, de ser precisa disposición para la pe- / nitencia la contrición, que justifica. Y siendo preciso el que / el sacramento dé algún fruto, se ve que ai frutos divisibles y / partes, dones y gracias que allí se ocultan, además de la / gracia que justifica.

Haga Vuestra Paternidad de lo que escreví arriba del pa- / recer de los theólgoos con el padre Melchor Cano ${ }^{278}$, que sienten / ser divisible la remisión

${ }^{277}$ El teólogo franciscano Luis de San Juan Evangelista sintetiza así el sentido de este aforismo: "El que antes del sacramento tenía sola la atrición, por virtud de él recibe la gracia y las virtudes sobrenaturales, y entre ellas la virtud de la penitencia, por lo cual habitualmente está contrito" (Tratado sobre el quarto del Maestro de las Sentencias, I, Diego Díaz de la Carrera, Madrid 1642, 381). Se trata, por tanto, de la formulación de la sacramentología y moral clásicas que sintetiza la enseñanza común de la Iglesia sobre el modo como la gracia actúa en el penitente a través de dicho sacramento en virtud de la disposición de aquel, moviéndolo de una contrición imperfecta (atrición o simple dolor de los pecados) a otra profunda y verdadera. Así, "el penitente, que llega atrito, se hace contrito, no sin el sacramento de la penitencia, que eso no puede ser..., sino mediante el sacramento de la penitencia, por el cual logra con la atrición los efectos de la contrición, pues logra el hábito de la gracia, y caridad, logra la remisión de los pecados, y conmutación de la pena eterna temporal, que son todos los efectos de la contrición" (J. Díaz de Benjumea, Adicciones a la Theología moral, y promptuario, que de ella compuso el muy reverendo padre Fr. Francisco Lagarra, II, Manuel Marín, Madrid 1758, 39; cf. J. Perry, A Full Course of Instructions for the use of Catechists; being an explanation of the Catechism, T. Jones, Londo 1852², 323-325; Renati Hyacinti Drouven, De re sacramentaria contra perduelles haereticos. Libri Decem, Tomus Secundus, Thomam Lettinelli, Venetiis 1756², 91). De donde se desprende que, mientras la contrición resulta suficiente para el perdón de los pecados, incluso sin confesión sacramental, el pecador está obligado a confesar todos los pecados mortales a fin de estar cierto de su perdón y la elevación al estado de la gracia (cf. DH 1678; Reconciliación y penitencia 31, nota 185; V. T. O' Keefe, The history and meaning of ex attrito fit contritus, Woodstock College Press, Woodstock 1957; J. T. Bretzke, Consecrated Phrases A Latin Theological Dictionary, Liturgical Press, Callegeville 2013³, 73-74).

${ }^{278}$ Conocido, sobre todo, por su obra De locis theologicis, el teólogo dominico Melchor Cano (1509-1560) fue uno de los discípulos preeminentes de Francisco de Vitoria (1485?-1546) y es uno de los representantes de la Escuela de Salamanca. Condiscípulo de Domingo Soto (1494-1560), regentó la cátedra de Prima de la Universidad de Salamanca a partir de la muerte de Vitoria (1546-1551) y participó como 'teólogo imperial' en el Concilio de Trento (1551-1552), asistiendo a las sesiones de la XI a la XVI. Presenció y contribuyó, por consiguiente, a los debates doctrinales y disciplinares vinculados con los sacramentos, tal como muestran sus discursos sobre la Eucaristía (9 de septiembre), el Sacramento de la Penitencia (24 de octubre) y el Sacrificio de la Misa (9 de diciembre de 1551). Su intervención conciliar sobre el segundo pareció ser especialmente significativa (cf. J. Alcalde, "El método teológico en la Suma": Ciencia Tomista 7 (1913) 261-264). No en vano, tanto en Alcalá como en Salamanca había mostrado su preparación teológica en esta materia, tal como muestran sus relecciones salmantinas De sacramentis in genere (1546-1547) y De poenitentiae sacramento (1547- 
de los pecados; porque dicen que ai / dos modos de perdonarse los pecados. Uno es perdonan- / do la pena eterna, remitiendo aquel reato y derecho de ///3r Dios que tenía acastigar las mortales culpas con eterna / pena. Por esto dicen no es menester dar gracia que justifi- / que entonces ni lo adopte por hijo de Dios, ni ia por esa / filiación divina tenga derecho el pecador a la herencia. Enton- / ces ese perdón no es de amistad, sino per intrinsecam con- / donationem, y ni por infusión de la gracia se le perdona / la pena eterna. Es perdón al modo del que dio David a / Absalón por la muger Heutiques, y fabor de Joab: Reducite / puerum Absalon ${ }^{279}$, dice que no le castigue por el enorme cri- / men del fratricidio; pero que no se ponga, añade, en mi / presencia: Faciem tamen meam non videat ${ }^{280}$. El otro modo / es dar el perdón entero y perfecto por la infusión de / gracia, por la infusión del Spíritu Santo que hace ia al pecador / hijo, y sele buelbe stolam primam, annulum in manu eius ${ }^{281}$, se / asienta a la mesa como hijo, como de el vitulo ${ }^{282}$ saginado, y / ai fiesta y música in caelis, et gaudium super illo pec(c)atore p(o)e- / nitentiam agente ${ }^{283}$. Esta Theología no está reprobada, y quizá / por mantenerla en su honor, quando el concilio pone ser pre- / cisa la contrición, añadió ad perfectam et integram remis $(s)$ ionem pec(c)a- / torum ${ }^{284}$. De que seve que para otros frutos menores noserá menester tan / grande disposición. Y quizá por la feê, buena voluntad y recta / intención conque se llega el miserable al Dios omnipotente le / da algún fruto,

1548). Por lo que se refiere a ella, expresa J. Belda Plans: "Nos encontramos ante un verdadero tratado teológico sobre el tema, por lo menos en cuanto al contenido: estudia con amplitud casi todas las cuestiones relacionadas, sobre todo las más importantes... Plantea con viveza y agilidad los grandes temas candentes de la época sobre la materia, para discutirlos y ofrecer soluciones... Se trata de una discusión teológica de gran altura y seriedad científica, rica y profunda... Hay gran profusión y riqueza de argumentación positiva y especulativa..., sobre todo de Sagrada Escritura y Santos Padres... Se puede apreciar un tono de conjunto sereno y ponderado... Para finalizar, señalemos que... es una pieza maestra de la teología de Cano" (J. Belda Plans, Melchor Cano, Biblioteca Virtual Ignacio Larramendi de Polígrafos, Madrid 2013, 71 y 76: http://www.larramendi.es/esc_sal/i18n/catalogo_imagenes/grupo.do?path=1021534; cf. D. Borobio, El sacramento de la penitencia en la Escuela de Salamanca: Francisco de Vitoria, Melchor Cano y Domingo de Soto, UPSa, Salamanca 2006).

${ }^{279} 2$ Sam 14,21. Variante: "Revoca puerum Absalom".

${ }^{280} 2 \mathrm{Sam} 14,24$.

${ }^{281}$ Lc 15,22. Variante: "Cito proferte stolam primam, et induite illum, et date annulum in manum eius, et calceamenta in pedes eius".

${ }^{282}$ Del lat. vitulus, $-i$ : ternero.

${ }^{283}$ Lc 15,7. Variante: "Dico vobis quo dita gautium erit in caelo super uno peccatore poenitentiam agente, quam super nonaginta noven justis, qui non indigent poenitentia".

${ }^{284}$ Concilio de Trento, sesión XIV, c. 4: I. López de Ayala, El sacrosanto y ecuménico ... 170 (DH 1704). 
menos o más según su feê, ia que no alcanza la / entera remisión de sus culpas por no llebar quizá contrición / ni aun imperfecta. ¿Qué sabemos si la cruz, por gracia y por exce- / so de su liberal grandeza, le quiso dar (porque quiere, y nadie le $/ /{ }^{53 v}$ puede limitar sus dones) la remisión de la pena eterna, hasta / que sea digno de la gracia y se acerque por contrición aella?

Y ia que no le perdone ni la pena, ¿por qué, quizá, no le dará otra / remisión? La remisión del derecho que Dios tenía por su justicia a ne- / garle muchas gracias auxiliantes que el pecador merecía por sus / culpas ser privado de esas gracias, y merecía caer enmaiores y maio- / res culpas, desgracias y penas, y aun el desamparo en el día último. / ¿Porqué no se ha(n) de esperar estos frutos de este sacramento, quando seven y se expe- / rimentan en otros? Vemos en el de la Eucharistía tanta diversidad de / gracias. Solamente con asistir en su presencia, y más al sacrificio / de la misa, da el sacramento algo que, aunque tenga muchos pecados, oie / la misa no pecando, sino con recta intención, fe y buena vo- / luntad, da mucho fruto y saca mucho provecho. Esto está tan / experimentado que es perpetuo consejo de los buenos a los malos el que / oigan misa cada día, y muchas, porque vemos que los malos que la / oien aum rústicamente son menos malos que los otros que no cuidan / de esta deboción: tienen más freno, son más avisados de Dios, sien- / ten frecuentes auxilios, andan más temerosos y con más deseos. / La Yglesia ni el sacerdote no los desecha, como no vaian ô asistan pe- / cando; pero anadie desecha como asista con feê, recta intenci- / ón y voluntad, pues ¿porqué este sacramento de la penitencia ha de tener / menos rédito que otros? ¿Porqué si de llegarse al Salbador en la / misa el pecador no contrito, sino cargado de pecados, de llegarse, / digo, con muchos males y crímenes, pero no pecando actualmente, / sino con buen deseo de sacar fruto, saca mucho, y el sacramento / tiene frutos que repartirle, aunque no sea el de justificarle por entonces?; //54r ¿porqué, pregunto, el de la penitencia ha de ser escaso con los que se llegan / aél por feê de la cruz, del Salbador? ¿Porqué, sino son dignos (que no sa- / bemos) de la gracia justificante, no les dará otros frutos menores? / (Sean los que se fuesen) por aver creído, por haber obedecido, por averse / humillado al confesor, por averse vencido en declarar aun hom- / bre sus faltas y fealdades, por esperar algún bien en la promesa / de Cristo, quorum remiseritis pec(c)ata, remit(t)untur eis ${ }^{285}$, y por la buena / intención y voluntad de alcanzar el perdón? Y singularmente ¿porqué / tenga algún efecto bueno el ego te absolbo, que con la seguridad de / la promesa de Cristo dice el confesor, invocando el nombre de el / Padre, y del Hijo, y del Spíritu Santo? Porque de otra suerte, si es la justifi- / cación el único efecto, fuera

285 Jn 20,23. 
frequentemente vano el ego te absolbo, y / fútil fuera, y sin provecho, el invocar sobre muchísimos, todos los / días, y acada hora la Santísima Trinidad y, como Vuestra Paternidad dice, de 20 y / apenas avrá uno en el que tenga verdadero sentido el ego te / absolbo. Y no es creíble que no tenga efecto casi frequentemente un sa- / cramento tan grande. No tenga Vuestra Paternidad por de ningún fruto la ab- / solución, que se da con ese inicio de creer y esperar y algún / buen deseo y algún amor, aunque sea pequeñito. Alomenos no / será sin fruto del Padre que la da bene, quia charitative con espe- / ranza del fruto, que aproveche algo al próximo.

\section{Regla X}

Dice mi Padre Maestro que ia con lo dicho tubiera anchura para, sin / escrupuloso cuidado, confesar y favorecer a muchos, si tubie- / ra una regla con la que se governara para indagar en cada uno / la verdad de su querer, de su pedir, de la rectitud de su ánimo en $/ /^{54 \mathrm{v}}$ recibir y desear el sacramento, porque se ve en muchos un querer / frío, seco, y ¿quéseio cómo por lo que escrupulizó de absolverlos; porqué / dudo que al querer sea voluntad ô belleidad? Es así, que ai querer y ai / quisiera. El querer es volo absoluto; el quisiera es vellem, que equivale / a querer condicionado. De el volo nace voluntas; de el vellem se origina / velleitas. Todos quieren ser buenos, porque eso es fácil y dulce; porque la / bondad aun delos malos es amable. Pero es un querer más veleidad / que voluntad. No es un querer resuelto que absolutamente sea volo y voluntas. / Y que en virtud de que dice volo pone todos los medios y quita todos los obs- / táculos. Es un querer de complacencia en lo bueno, pero en orden / a conseguirlo, en hallando dificultad, se acabó el querer. No es volo, sino / vellem, que es lo mismo que quisiera si no costara trabajo el vencimiento / de los vicios, ô es un querer condicionado, el que no basta para la absolu- / ción, y lo desecha toda la Theología. Véase aquí mi escrúpulo, dice Vuestra Paternidad, / porque, aunque todos por lo común dicen que quieren, vemos que tropezan- / do con la dificultad de dexar la ocasión, de restituir honrra o ha- / cienda, de dexar vino, juego y amigos, por medios precisos para la em- / mienda de los pecados, que dicen quieren dexar con boluntad bue- / na, se ve que no fue voluntad, sino velleidad y alguna complacen- / cia, no haciendo nada de lo que se les aconseja. Este, creo, es el fon- / do, dice Vuestra Paternidad, porque no manda la Yglesia que no se debe creer, y por eso / ni absolber alque dice que se emmendará porque solo lo diga, sino / ai otras señas conque se conosca que quiere de veras y que no es pura / velleidad su querer. El mismo fondo creo que tiene la doctrina de / los moralistas que enseñan no deverse creer al peni- 
tente que dice / quiere ia emmendarse desu viciosa costumbre, sino lo exe- //55r cuta aun después de haberlo dicho tres veces.

Esta es mi duda última que propongo, dice Vuestra Paternidad, para mi total so- / siego. A lo que digo que esta duda no es en mi Padre nueba. Es la misma / misma que siempre ha propuesto desde el principio; porque todo el / escrúpulo de Vuestra Paternidad ha sido siempre, y consiste únicamente, en ver que / no se emmiendan, aunque lo proponen; y ahora es el escrúpu- / lo el mismo. Pues, quando se emmiendan, nadie escrupuliza ni, en vi- / endo esa enmienda, nadie indaga más de si tubo contrición ô no, / de si trae los actos mandados por el tridentino. Ni acaso la em- / mienda (tal qual trae) es efecto quizá de causa natural, ô de prin- / cipios espurios, que no sirban para el sacramento. Porque solamente / con ver no digo total enmienda, sino aminoradas las culpas, / ô en algún vicio emmendadas, o que se vio alguna resistencia antes / de por fin cometerlas, ia por reglas del(a) moral se puede creer / que trae voluntad y querer verdadero para absolverlo sin escrúpu- / lo. Y como Vuestra Paternidad ve que no se emmiendan esos malos, que tanto le / fastidian, de aí le nace(n) y le ha(n) nacido siempre sus dudas y escrúpu- / los. Y io ¿qué he hecho en todo este escrito? Darle a Vuestra Paternidad a entender / que no tiene obligación el confesor a tanto como ver y palpar / la contrición y evidenciar la dignidad del sugeto, oliendo que / hace los actos precisos; sino que, para dar el sacramento honeste, ordinate / et charitative, basta el que vea que el sacramento le será útil al peni- / tente, y por si forte lo merece, no sea que peresca por mi culpa, / y porque de negarlo no se espere bien ninguno, y de darlo charitative / no ai que temer mal, y además se espera mucho bien. $\mathrm{Y}$ añade: que / aunque no vengan emmendados, puede ser que traigan las dos cosas $/ /{ }^{55 v}$ precisas, que son creer y querer de veras. Y ahora buelbe / mi Padre / a dudar. Y ¿sobre qué? Sobre lo mismo de que no se emmiendan y que, / sino se emmiendan, ia no ai nada, ni ai voluntad verdadera / que sirva para el consuelo, sino velleidad mísera que abominan / los theólogos.

No obstante, digo â Vuestra Paternidad que confunde, como si- / empre, lo falso con lo verdadero. Ya se ve que es cierto, y no / basta para dar la absolución, la que se llama velleidad, porque / equibale no aquerer absoluto (este es el que se llama verdadero), sino / â condicionado, que dice quisiera. Sino hubiera de pormedio este / o el otro embarazo, verbigracia vellem, quisiera ser casto; quisiera ser justo / y dexar los robos, porque es cosa bella la castidad y la justicia. Quisiera, pero / de esos vicios paso, como y visto, y sin ellos peresco, y por eso en ver- / dad no quiero, aunque quisiera como otra cosa no lo estorbara. / Por esto el vellem, ô quisiera, que no es voluntad, sino velleitas; / no sirbe de nada para la absolución, porque no es verdadero querer / ni es amor de la justicia y de la virtud sobre todas las cosas, el que ha de ser / absoluto, y 
el condicionado, si es expreso, es pecaminoso y hace al hombre / claramente indigno del sacramento. Esto es cierto, y nadie duda de los theó- / logos. Pero es falso el que la falta de emmienda sea siempre señal de que / el querer del reo que pide ser absuelto no sea verdadero y absoluto; / porque una cosa es que sea querer flaco y pequeñito, otra cosa es que / sea veleidad o condicionado.

Es así que puede ser (y sucede frequentemente) que el peniten- / te, que propone vere et absolute la enmienda, caiga en las oca- / siones mismas, y no sea la causa no haber sido por entonces la //56r voluntad verdadera. Puede ser que la causa sea o la ignorancia (que / es en muchísimos profundísima) o la fraqueza y peso, ia im- / menso, de la concupiscencia irritada ia con el dilubio de culpas. Por / esto, quando el confesor charitatibo y prudente, indagando bien estos / fondos de ignorancia y flaqueza, juzga como juez que el querer es / verdadero, da la absolución charitative, esperando de la virtud de el / sacramento que fortalecerá aquel inicio y querer flaco, y le hará más / provecho que el negarlo melendroso, trepidando timore ubi non / erat timor ${ }^{286}$, de lo que quedará por su zelo mui satisfecho, debiendo / quedar más escrupuloso, porque ignora si le pribó de algún fruto / haciéndole quizá mucho daño. No es, pues, lo mismo ser el que- / rer flaco o no ser verdadero y absoluto. Puede ser ese querer semilla / que produxo el Spíritu Santo. Y no por no ser verdadera, sino por caer / entre piedras, no llebe el fruto deseado de la emmienda y mudan- / za de vida. La semilla de la parábola verdadera fue, y aun nació / en verdad, y si natum aruit, no fue por no ser grano verdadero, que / sembró el labrador divino, sino por la dureza del terreno, que / non habebat humorem, natum granum aruit ${ }^{287}$. Así son muchos que / bienen con buen ánimo, buen deseo, vuena voluntad, y verdade- / ra feê, pero quia radices non habent, se seca y se marchita la / voluntad buena, y sucede que ad tempus vere credunt, sed intem- / pore tentationis recedunt $t^{288}$.

Puede ser también creer en esto o en lo otro los que tubie- / ron verdadero ánimo por ser este flaco y pequeño, y por el caso que / hubo que vencer ser caso arduo respeto del sugeto. No fue falta / de feê verdadera en san Pedro, quando andubo por supie sobre las aguas //56v fiado de la divina palabra, por haber después flaqueado en la / arduidad del viento válido y violento, que lo sumergía teme- / roso. Fue pequeña feê, no falsa sino verdadera, fe apocada / y medrosa, modica fidei (le dice el Maestro soberano) quare dubitasti? $?^{289}$ / Pero no le acusa de que no tubiera feê ninguna, sino que, siendo / verdadera, aún

\footnotetext{
${ }^{286}$ Sal 13,5; 56,6. Variante: "Illic trepidaverunt timore, ubi non erat timor".

${ }^{287} \mathrm{Lc} 8,6$.

${ }^{288} \operatorname{Lc} 8,13$.

${ }^{289}$ Mt 14,31
} 
era poca y flaca. También fue caso arduo / por las circunstancias el confesar a Cristo quando le negó acobar- / dado, y por eso no fue seña de que no fue verdadero ánimo o vo- / luntad absoluta, quando protestaba con tantas veras, si opportuerit / me mori tecum, non te negabo ${ }^{290}$. Assí sucede que, para muchos, es / caso arduo esto o lo otro, por aquel o por el otro motibo, en esta o / en aquella persona y circunstancia, y por eso caer en lo mismo / que proponen emmendarse verdadera y absolutamente. No / es, pues, seña de aver sido el querer del penitente vellei- / dad o no querer absoluto y verdadero el volber a pecar otras / veces, porque puede ser, ser el sugeto miserable, ignorantísimo, / rusticísimo, mal criado, mal habituado, y por ser flaquísimo, / ser lo que se le manda caso mui arduo.

Si esto es así, dice Vuestra Paternidad, ¿porqué no basta para asegurarse el con- / fesor de la verdadera voluntad del penitente, el que este diga de voca / que la tiene como la proposición condenada, dice, sino que se atienen / â las obras, que son buenas señas operibus credite ${ }^{291}$ ? Y luego que no ven / los theólogos emmienda, aunque la han prometido los consuetudina- / rios tres veces, ¿no creen más viendo que aquella voluntad no es / verdadera, sino veleidad mísera? Ni creen toman el sacramento / seriamente con intención recta, sino por motivo espurio, ô por $/ /{ }^{57 \mathrm{r}}$ pasatiempo, por lo que san $(c)$ te $e$ juste se les niega el sacramento / o por castigo, o por indignos, o por charidad, viendo que no sa- / can provecho alguno, antes daño, con la facilidad que ven se les / da la absolución, con que más la burlan que la estiman. ¡Mucho / escrúpulo es ese, padre Maestro! Pero no ai para qué ni porqué seme / afliga Vuestra Paternidad; antes eneso mismo se ven las dos cosas dichas. Porque se ve, lo uno, que todos van mirando a asegurarse en el pe- / nitente qué quiere en verdad, y que trae buena intención, y so- / lamente disputa sobre buscar señas, y estas nunca pueden ser en / todos ciertas o certísimas para la seguridad objetiva, pero basta / que sean tales que se juzgue prudenter que el confesor obra cier- / tamente bien si absuelbe, por si forte al reo le sirbiese, dándole / por eso entonces charitative. Se ve también lo otro, que siempre / se debe obrar â fabor y en utilidad del próximo, que se le dé o que / se le niegue la absolución, desuerte que, si se niega al que no la esti- / ma ni la desea, ô que de darla sacaran mal y (se) burlaran de el sacra- / mento, o que más se relajaran viendo anchura y facilidad en el / perdón, o porque negarla será para freno, para castigo, que humille / el orgullo del soberbio, y por eso venga otra vez emmendado. / Si se niega, digo, por estos motivos, o por otros justos que la pru- / dencia y charidad del confesor debe prever y examinar, se

${ }^{290}$ Mt 26,35.

${ }^{291}$ Jn 10,38 . 
/ niega siempre por charidad ô porque el negarla es bien de el / próximo, que le es más útil que darle el sacramento, esto no lo niega / nadie, por lo que no tiene mi Padre que afiglirse.

Pero ia ve Vuestra Paternidad que estos casos enque se vea que el sacra- / mento daña no son tan frequentes, como dice, que de veinte $/ /^{57 v}$ apenas ai uno que se pueda absolber con seguridad. Porque tal / charidad, que non cogitat malum et non irritatur ${ }^{292}$, halla motibos / para esperar bien de la absolución. Ella, aun entre tantos males, / como no le irritan, sino le compadecen y se conduele, en- / quentra con alguna regla de disciplina saltem en la ignoran- / cia. No ha avido en el mundo maior maldad que el deici- / dio, ni pecadores más abominables que los que crucificaron / â Dios hombre. Y este santo charitatibo Señor halló entre / tanto mal algún bien para absolberlos con exemplo asom- / broso del mundo: Ignosce illis (decía a su Padre) quia nesciunt / quid faciunt $^{293}$. Y aunque no todos fueron dignos del perdón, pero / el Salbador obró bien, y con tanta altura de perfección que no / cabe en nuestra imitación y capacidad tanta grandeza de / virtud. Norabuena que convenga con algunos el rigor, pero / siempre por charidad. Esto es para el bien de el malo y perdido. / Por esto debe temerse mucho no sea ira e irritación el castigo, y / no charidad, quae non irritatur ${ }^{294}$, quizá enesos celosos y ri- / goristas no se hallará la aprovación del Salbador, como ni / aprovó el zelo de los discípulos que, enojados contra los in- / crédulos samaritanos, querían bajase fuego de lo alto sobre / ellos ${ }^{295}$. Norabuena sea que en algunos no se vea la buena volun- / tad. Pero aquí la charidad del confesor prudente hace (con / saber loque le debe $\operatorname{dir}^{296}$ ) que la comienze a tener enaquella / hora, sino venía antes con voluntad buena y absoluta. Y si / da la absolución, la da de modo y taliter y con tales precap- / ciones que ni el más desevergonzado le burle, ni el más diso- $/{ }^{58 r}$ luto por ella se relaxe. Antes se procura dar siempre / quando y como aproveche. Y que alomenos se espere fruto, poco / o mucho, y nunca daño. Ame Vuestra Paternidad a los miserables, y la charidad / que mira â remediar loque pudiese su miseria dará luz de / una práctica santa, que no se puede ceñir ni enseñar por / reglas, porque consiste en penetrar lo que cada uno ha de menester. I

Por esto está juste condenada la theología que quitaba al / confesor juez la obligación de penetrar en cada uno loque con- / biene para absolvelo. Decía

\footnotetext{
${ }^{292} 1$ Cor 13,5 .

${ }^{293}$ Lc 23,34. Variante: "Dimitte illis: non enim sciunt quid faciunt".

${ }^{294} 1$ Cor 13,5 .

${ }^{295}$ Cf. Lc 9,54.

${ }^{296}$ Se trata de una errata. Se presume que debe decir 'dar'.
} 
que bastaba que el reo afirmase de / boca su voluntad santa y enmienda futura. Y con esta sóli- / da diligencia podía el juez absolver sin más obligación. Esto ia / se ve quám falso es, ageno de toda verdad de toda verdad, porque es quitarle al / ministerio la razón de judicatura, la de tribunal, y al confesor / la razón de juez, y de juez interior. Porque, si de qualquiera ma- / nera se debía atener este aloque el reo dixese de boca sobre su / causa misma, él fuera el que se sentenciara y el penitente fuera el / árbitro en aquel tribunal, y no el confesor. Porque este no tubiera por / qué ni para qué indagar la causa, ni para qué oírle los alegatos y delitos, / ni hubiera motibo porqué está mandado que el penitente diga entera / su causa sin ocultar cosa grave ninguna. Pues se debía siempre / atener, para sentenciar o absolber, esperar aoír de la boca del reo / mismo definido su pleito. Porque con solo oír que el culpado decía que / la emmienda estaba segura, aunque fuese quizá un falsario y en- / bustero, el juez debía callar, creer, absolber y sentenciar agusto de / el reo, según lo ha determinado, y con precisión de que se esté asu dicho, sea falso, / o verdadero. Esta theología ya se ve que es falsa y mui perjudicial por- $/ /^{58 v}$ que debe el confesor, como juez interior, indagar si el reo que dice / de boca y a fuera que emmendará sus culpas dice la verdad, y que / corresponden las palabras de sus labios con loque tiene adentro / en su pecho y ánimo.

Por esto le toca al confesor penetrar aquel conjunto de la con- / fesión del reo, y ver si ai señas y motibos prudentes y charitativos, / por donde juzgue ambas cosas. Una, que el penitente confiesa y pide la / absolución en verdad y con recta intención; la otra, que le serbirá el / sacramento no de daño, sino de provecho, y aunque no sea seguro cier- / tamente, saltem por si forte le sirviese, lo da quando no ai claro motibo / de lo contrario. Desuerte que, no habiendo motibo encontrario para sos- / pechar que el confidente, que propone emmendarse, es embustero y doloso / y que habla fingiendo, engañando, es charidad creer al cristiano. Y fue- / ra juicio temerario creer del próximo que era doloso, sin fundamento. / Por eso vemos que los theólogos creen una, dos y tres veces al peniten- / te que propone emmendarse hasta que ven, por la experiencia fina, / que no habla con voluntad verdadera. Pues en verdad que la propo- / sición condenada ni una vez quiere que se dé la absolución por solo / el dicho del penitente. Enque se ve que, dándola los theólogos una, / dos y tres veces, es por juzgar charitativamente que el reo no mien- / te, y la dan esas veces no por solo el dicho del penitente, sea o / no sea falsario el reo, como que no le toca al confesor juez interior / (esto es lo conenado), sino que ladan porque, examinada la causa, / no hallan motivo justo para juzgar mal del próximo, dándolo cierta- / mente por embustero. Pero después de tolerado tres veces sin em- / mienda, no creen ia su verdad, y no es falta de charidad ni ia $/ /{ }^{59 r}$ juicio temerario creer que es un doloso con tan grave fundamento. / 
De aquí se ve que el litigio ia no es sobre la condenada theo- / logía, sino sobre si ai o no ai fundamento grave y conbincente para juzgar del reo sobre su falsedad o novedad, sospechando / de su falsa y no recta intención. Este es un mar donde siempre / es preciso perder el pie o naufragar en dudas para la práctica en / tan diferentes genios y condiciones de personas, con diversas / costumbres, ignorancias y flaquezas. Por esto, los mismos theó- / logos dudan por regla fixa de esa trina experiencia. Ya save / Vuestra Paternidad quántas excepciones ponen los theólogos mismos sobre eso, / limitando esa regla en muchas circunstancia por las que creen / que, aun después de las tres veces que ha venido el penitente sin em- / mendarse, aún reciben su confesión, quarta, quinta vez como ver- / dadera. La creen no solo quando ai o traen extraordinaria moción (con / la que ia no solo se absuelben los reos, sino que comienza de nuebo el / número trino para, aunque no se emmienden, absolberlos) ô se ve / que algo resistió antes de caer, ô porque fue la exortación tal del con- / fesor, que cree que le hizo fuerza para proponer de veras desde ahora aun / estando encontra la trina experiencia. Deque seve que esta no siempre / es regla fixa para dar por embustero al penitente si la quarta vez / viene sin enmendarse. Servirá aveces según la penetración del / confesor en todo el conjunto de sugeto, tiempo, circunstancias, casta / de pecados más o menos fáciles de cometerse; pecados que más / son de ignorancia que de malicia, más de flaca condición que de afir- / mada voluntariedad. Esto llama el Agustino veniales, esto es, faci- / les ad veniam, cuio dicho está injerto en el cuerpo del derecho. Nullum $/ /{ }^{59 \mathrm{v}}$ pec(c)atum est adeo veniale, quod non fiat criminale, si placet ${ }^{297}$.

${ }^{297}$ Tal como dice el autor, esta distinción entre pecado criminal y pecado venial integró el cuerpo del derecho. Así lo muestra que figure, por ejemplo, en las glosas jurídicas que Gregorio López realiza a la Primera Partida, título cuarto, ley XXIII de las Siete partidas de Alfonso X el Sabio; cuando comenta las tres cosas que, según el rey, se han de cumplir para hacer penitencia verdadera, y más concretamente el hecho de confesar verdaderamente los pecados (cf. Alfonso X, Las siete partidas, glosadas por el Lic. Gregorio López, I, León Amarita, Madrid 1829, 46-47). Graciano atribuye esta máxima a Agustín, y así lo recogen autores como Augustini Barbosae Lusitani, Collectanea Doctorum, tam veterum quam recentiorum, in Jus pontificium universum, V, Anisson y Posuel, Lugduni 1656, 86. En un estudio sobre las Siete Partidas, también se da esto por hecho, situándolo en el marco de la reflexión teológica en torno al pecado y el crimen, abierto por Abelardo, si bien en el derecho eclesiástico hay que remitirse al Decreto de Graciano, "donde por primera vez se formularía jurídicamente la idea de crimen", si bien en las fuentes que utiliza el crimen carece de esta especial significación jurídica. Este aspecto lo trata en dos lugares: el señalado por nuestro autor (D. 25, dictum post c. 3), y el D. 81, c. 1. Graciano emplearía el aforismo agustiniano para remarcar el carácter premeditado del crimen (dum placet), por oposición a los pecados realizados por ignorancia o infirmidad (cf. A. Morin, "Muertos y pecados en Primera Partida: la noción de pecado criminal en Alfonso X": Anuario del Centro de Estudios Históricos Prof. Carlos S. A. Segreti 7 (2007) 381-386). No se debe olvidar que este comentario de Graciano se basa en la correspondiente glosa al versículo de Tit 1,6: "Si quis sine crimine est".

Sobre la gradualidad del pecado en Agustín de Hipona, s. 77B, 7; c. Jul. imp. V,13, PL 45,1442- 
Assí / lo cita Graciano en el decreto dist. 25, capítulo 3. Pero los correctores / romanos añaden: Quod in glosa ordinatia citatur haec senten- / cia Agustini hoc modo: Nullum pec(c)atum veniale est, dum placet quan- / tum cumque parvum, sicut mortale, si vere displicet, nullum judicat. / El mismo Graciano cita ai a san Gerónimo. Assí: Hyeronimus / in Epistola ad Occeanum dicit: Ut res contra naturam p(a)ene est / ut sine pec(c)ato quis vibat ${ }^{298}$. Et bene Beda: Pec(c)ata quae ex igno- / rancia vel infirmitate humana comituntur, dicit, et pr(a)e- / cipit alterutrum confiteri, quia facile dimit(t)untur. Qu(a)ecumque I vero fiunt ex deliveratione non misi per p(o)enitentiam. / Ygnorando, pues, el confesor la causa de esas caídas más o menos / graves, ni sabiendo quánta ignorancia o flaqueza ai en la persona / ni quánta deliberación y complacencia en las culpas, es preciso que / no sea regla fixa en todos la trina experiencia. Y ciertamente, / si esta quarta vez fuese tan irremisible como el quarto delito de / de Damasco, del que dize el sagrado texto: Super tribus sceleribus / Damasci, et super quartum non convertam illum ${ }^{299}$, no hubiera el sal- / vador extendido el número usque septuagies septies ${ }^{300}$, esto es, / toties quoties, con tal de que de veras quiera, y pida, no sirbiendo / de estorbo, sino ai otro motivo, la repetición trina sin emmienda. /

\section{Regla XI}

Ya me parece que oigo a mi Padre Maestro pedir con ansia reglas / para discernir estas cosas, y conocer entre tantas tinieblas la volun- / tad verdadera distinguiéndola de la falsa, / sed rem di(f)ficilem / postulasti ${ }^{301}$, Pater mi. Ya dixe â Vuestra Paternidad al principio ser impsible //60r reducir a reglas abstractas la práctica de la penitencia, con infinitas / personas, diverse et infinite circunstanciadas. Ni podré estampar en / el papel el cómo io lopractico; ni el porqué veo que uso el ministerio sin / escrúpulo, ni lo que les enseño, los corrijo, los medico, los absuelbo mi- / rando asu fruto, ni en qué conozco lo que hamenester cada uno para mi- / nistrarlo, y en poco tiempo, sin detención, ni fastidio, o admiración de / las gentes, que aguardan aun siendo confesiones

1443; c. mend. VIII,19, PL 40,529-530; en. Ps. 39,22, PL 36,447-448; ench. 19,71, PL 40,265-266.

${ }^{298}$ Esta máxima, muy socorrida en tratados jurídicos eclesiásticos, posiblemente se ampare en las afirmaciones de la ep. 69,8 (cf. san Jerónimo, Obras completas, Xa, BAC, Madrid 2013, 768 770), a raíz de la explicación de Tit 1,6.

\footnotetext{
${ }^{299}$ Am 1,3. Variante: "Super tribus sceleribus Damasci, et super quatour non convertam eum".

${ }^{300}$ Mt 18,22.

${ }^{301} 2 \operatorname{Re} 2,10$.
} 
generales muchas / veces y precisas. Ni en qué ô porqué veo sin escrúpulo y consuelo mío / que obro bien, y que hago bien al próximo, y hago lo que puedo con el / miserable por más que el sentido me moleste con imágenes de que aquel se- / nos pierde. Nada puedo decir destas cosas ni aun aboca, ni por plu- / ma, por ser esta una práctica diferente con cada persona, necesitan- / do unas de una doctrina, de una medicina, de un modo de corrección, de / freno, de castigo, de reprehensión, para hacerles bien; y otras de diver- / sas modas, doctrinas, castigos, reprehensiones y amenazas, alagos, disi- / mulos, según los genios y vicios, ciencia o ignorancia de los sujetos. / Y con algunos no se puede nada por párvulos (no en la hedad solo) por semifatuos /, por sordísimos, por tartamudos, o mudos, que no entienden, ni los / entendemos, por delicados y enfermos, por vergonzosos y tacitur- / nos, y por cosas que hacen imposible hablar de ellas reduciendo / â reglas su práctica.

No obstante, pide Vuestra Paternidad regla para discernir entre tantas ti- / nieblas la verdadera voluntad de la falsa. Aquí digo que las tinieblas / están afuera, en las almas perdidas. Pero al confesor bastante luz / se le ha dado en este ejercio para que, sin tinieblas y seguro, obre su mi- / nisterio. Ecce tenebr(a)e operiunt terram, et caligo populos ${ }^{302}$. Pero super $/ /{ }^{60 v}$ te mi Pater, oritur sol justitiae et inte(l)ligentiae, et gloria charitatis in / te videtur ${ }^{303}$. Porque ia sabe Vuestra Paternidad su obligación, y que no puede pasar de / aquí, esto es, de ministrar el sacramento in bonum y utilidad del mísero, / con tal de que crea, espere, pida, desee y quiera con voluntad recta y / santa. Entonces se da charitative, honeste et laudabiliter, y para quien loda fructuose. Esto no es tinieblas, sino luz clara, que reconoce la prudencia charitativa. La charidad y prudencia no es tenebrosa. / Las tinieblas están en los otros, que no nos hacen daño como no quer- / ramos entrar en ese chaos, en lo que no nos toca ni podemos remediar / nada. Ya dixe a Vuestra Paternidad que era preciso, mesclados réprobos con los escogidos, / que se expusiese el sacramento al mal uso e indignidad de muchos incré- dulos. Pero no tocándonos segregar ia la semilla zizaniorum del gra- / no preelecto, debemos hacer bien a todos por si forte son escogidos, y de / los nuestros, y por el sacramento les damos la mano para que salga la / margarita del lodo ${ }^{304}$. Sea la prudencia en la voca de Vuestra Paternidad como el sol de lu- / ces y enseñanzas que oriri facias super bonos et malos $^{305}$. Sea su chari- / dad nube blanca y de gloria que derrame llubias et

\footnotetext{
${ }^{302}$ Is 60,2 . Variante: “operient”.

${ }^{303}$ Posiblemente, en sentido inverso, esté recreando Sab 5,6.

${ }^{304}$ Cf. Mt 7,6.

${ }^{305}$ Mt 5,45. Variante: "Qui solem suun oriri facit super bonos et malos".
} 
beneficencias / super justos et injustos ${ }^{306}$, y será Vuestra Paternidad parecido al Padre celestial que así mira / con misericordias múltiples a toda la tierra tenebrosa con tantas / abominaciones e injusticias: Misericordia Domini plena est terra ${ }^{307}$. Y ¿qué / maior luz y claridad que parecerse el hombre â Dios en el obrar? ¿Qué más consuelo que solo tener en ese oficio el cuidado charitatibo de indagar / lo más que se puede la buena voluntad del penitente que pide? No se que- / xe, pues, Vuestra Paternidad de tinieblas. Estas son agenas, no proprias, cuio cuidado y / remedio se dexa al Divino Juez, contentándonos nosotros con aiudar / a los míseros en lo que podemos, dándoles charitative el sacramento que está //6rir â nuestra mano.

No podemos remediar al mundo, que in maligno e $(s t) \operatorname{positu}(s)^{308}$, non omnes obediunt evangelio ${ }^{309}$, aun los que profesan el cristianismo, / ni aun los que profesaron cumplir sus consejos. Pero si piden, quieren, / desean el sacramento para su remedio, los sufrimos, no los desechamos su- / per cilio Pharis(a)eorum ${ }^{310}$. Quisiéramos dar el sacramento como comvenía / si viniesen los penitentes como se desea. Quiséramos que su confe- / sión fuera hecha humiliter, pure, fideliter ${ }^{311}$, pero no se ven fácilmente / estas tres cosas, porque ai muchos que dice el Profeta que gloriantur cum / malefecerint, et l(a)etantur, vel ex(s)ultant in rebus pe(s)simis ${ }^{312}$. A los que / nota el sabio pe(c)cata sua, sicut Sodoma pr(a)edicaverunt ${ }^{313}$. Estos, si / la charidad no los humilla con la prudencia del confesor, bienen sober- / bios y no humillados, y es preciso tenerlos por indignos mientras / humildes no clamen, pidan y deseen, por donde se conosca voluntad / ia recta de la emmienda futura. Quisiéramos que

${ }^{306}$ Mt 5,45.

${ }^{307} \mathrm{Sal} 32,5$.

${ }^{308} 1$ Jn 5,19 .

${ }^{309}$ Rom 10,16.

310 "Superba interrogatio et plena de supercilio Pharisaeorum" (san Jerónimo, s. Matth. I,9,14, SC 242,172; cf. II,15,23, SC 242,330).

${ }^{311}$ Era doctrina común en la época que "tres condiciones debe tener la buena confesión del christiano para que sea aceptable a su Dios ofendido: humildad, pureza y fidelidad", tal como sintetiza Gerónimo Bautista de Lanuza, Discursos predicables, V, Imprenta de la Viuda e Hijo de Marín, Madrid 1803, 117. V.gr., Jacobo Tiran, Missionarius seu vir apostolicus in suis excursionibus spiritualibus, I, Leonardum Plaignard, Lugduni, 1692, 227; Paulo Gabriele Antoine, Theologia universa, speculativa et dogmatica, complectens omnia dogmata et singulas quaestiones theologicas, VI, Jacobum Clousier, Parisiis 1736, 167. Toman como fuente Bernardo de Claraval, Serm. 16 in Cant 7-15, SC 431,56-58.

\footnotetext{
${ }^{312}$ Pro 2,14. Variante: "Qui laetantur cum malefecerint, et exsultant in rebus pessimis".

${ }^{313}$ Is 3,9. Variante: "Et peccatum suum quasi Sodoma praedicaverunt".
} 
fuera la confesión / pura vel simple, pero vemos que muchos más se escusan que se acusan, que tapan, que callan, que aminoram la culpa, ia que ladigan, y que, aun cul- / pados, tienen por afrenta el ser reprehendidos, y quisieran que el confe- / sor no atendiese, ni hiciese tanto caso desus pecados, ni los ponderase / ni abultase tanto, siendo en el juicio de ellos cosilla de poco monto. / Últimamente quisiéramos ver a los penitentes confesar fideliter. La con- / fesión es cosa vellísima, pero si non est fidelis, no vale nada. La con- / fesión fielmente hecha es confesión in spe veniae ${ }^{314}$, no desconfiando to- / talmente de indulgencia del todo de sus pecados. Porque confesión no / confiada ella al reo, más lo condena por su misma boca que lo justi- / fica. Judas y Caín, ambos confesaron sus enormes delitos. Pero des- $/ / /^{61 \mathrm{v}}$ confiaron uno y otro. Aquel confesó pec(c)avi, tradens sanguinem justum ${ }^{315}$. / Este, maior est iniquitas mea, quam ut veniam merear ${ }^{316}$. Muchos vie- / nen a confesar sin confesión fiel, unos vienen más presumidos ô / presumiendo de sí, que esperando en Dios. Es presunción propia, / no fiel esperanza, quando dicen que esperan misericordia. Proponen la em- / mienda como cosa fácil, como que en sus fuerzas consiste el todo de / su salbación, su virtud, su charidad, el perdón, la gracia, la indul- / gencia, la perseverancia en el bien, creiendo y el esperando mui poco / de Dios, con lo que no es fiel su presumptuosa confesión. Otros, viendo / que no se emmiendan y que la concupiscencia les arrastra, los abru- / ma, se dexan caer con la carga misma y, viviendo ia gustosos con / aquella suerte que creen Dios mismo les ha dado, ia tienen hecho el / ánimo â condenarse, hacen pactum cum morte et inferno ${ }^{317}$, y, perdi- / endo la feê de uno y de otro, juzgan pasar aquel mal camino co- / mo aprehenden que lo pasan otros. En estos ai más y menos des- / confiados, y de buena gana no confesarán nunca, y, si por ser / preciso, les obligan, ô callan, ô si se les reprehende y amenaza con / las llaves eternas, nada les hace fuerza, nada estiman, porque nada / esperan. Esta falta es la más ordinaria, la que más aflige â / los confesores: Propter incredulitatem et de spem en que han caído / los malos por la reiteración de los vicios y tinieblas en que están / sepultados sus ánimos, no se puede ia nada con ellos; porque el / confesor no tiene más armas contra su vida mentirosa que la verdad / de la feê. Por lo que, si el penitente no cree, o si cree algo por no haber / aún renunciado el cristianismo, es tan endeble su feê, que hablar de / ella con esos de cosas futuras y prometidas o amenazadas, es lo mis- //62r

${ }^{314}$ Trento, sesión XIV, capítulo 4: I. López de Ayala, El sacrosanto y ecuménico... 152 (DH 1678). Variante: "Cum spe veniae".

\footnotetext{
${ }^{315}$ Mt 27,4.

${ }^{316}$ Gén 4,13 .

${ }^{317} \mathrm{Cf}$. Is $28,15.18$.
} 
mo que hablar con las bestias para enseñarlas a leer y a escribir. Vea aquí, / mi Padre, la justa aflicción que experimentamos todos: ver que no vienen / los penitentes perdidos a confesar ni humiliter, ni pure, ni pruden- / ter. Estas son tres fatales señales de no venir con buena voluntad. / Y, si fuesen cosas claramente conocidas, no fuera bueno, ni charidad, / darles la absolución. Pero, no obstante, vienen convinadas con / otras señas y circunstancias, que dexan campo a la charidad, / para que crea y espere algún bien y poder absolber al próximo por / charidad, y por eso sin daño de nadie, antes con fruto saltem / proprio et ideo sin escrúpulo.

Ya guerra Vuestra Paternidad saver: ¿qué señas son estas que la charidad en- / cuentra aun en esos malos para creer y esperar de ellos algún fru- / to? A que digo que la charidad, que por su condición omnia credit, omnia sperat ${ }^{318}$, se alegra de no ver claramente que el penitente es / indigno para esperar algún fruto, dándole con el sacramento algún / alibio; como algo que está caído es charidad alargarle la mano, aunque / esté el caído con alguna perlesía que no pueda alargar la suia, y serle / frustre al charitatibo su diligencia. Además, como el Salbador, que dilexit in finem $\operatorname{suos}^{319}$, halló en la ygnorancia de los que le crucificaban / disculpa para absolberlos, perdonándolos, así el confesor, que no se irri- / ta con los penitentes, ni los fastidia, ni soberbio los asquea, sino / que los ama, y por hacerles bien, aiudarles, los oie, halla en su / ignorancia mucha disculpa para creerlos y hacerles el fabor y beneficio de darles el sacramento, esperando dé la charidad de Dios algún / fruto. San Pablo atribuie a su ignorancia en perseguir la Yglesai el / haber alcanzado misericordia, ideo misericordiam consequtus, quia //62v ignoranter feci ${ }^{320}$. San Pedro da esperanza del perdón de el maior pe- / cado del mundo (el deicidio), diciéndoles: Scio, fratres, quia per / ignorantiam fecistis, p(o)enitemini, ut deleantur pec(c)ata vestra ${ }^{321}$. Es pro- / videncia misericordiosa el dexar Dios al mundo en tanta ig/ norancia para tener menos que castigar su justicia, y encontrarse / motibos para usar su misericordia. Esta ignorancia en tan / muchísimos de esos (que le causaban horror â Vuestra Paternidad y io experimento / cada día, que me parecen esas fealdades coram Deo como nada, ô de las que dice el Agustino son veniales, o faciles ad veniam, así como / son ningunos (aproporción) los pecados de los fatuos y párbulos sensu, / de cuias injurias aun los hombres no se resisten, ni se enojan, como ni aprecian sus alabanzas). Así Dios desprecia

${ }^{318} 1$ Cor 13,7 .

${ }^{319} \mathrm{Jn} 13,1$.

320 1Tim 1,13. Variante: "Sed misericordiam Dei consecutus sum, quia ignorans feci in incredulitate".

${ }^{321}$ Hch $3,17.19$. 
esas más / simplezas que culpas, atendiendo a la ignorancia, como san Pablo / decía â los atenienses: Et tempora quidem hujus ignorantiae /despiciens Deus, nunc annunciat (hominibus), ut omnes ubique p(o)enitentiam / agant ${ }^{322}$. Así, la charidad cristiana, viendo a los malos sepulta- / dos en tantas ignorancias, se compadece y se afirma y espera, / que Dios quizá despiciat misericorditer, y que nunca ia hodie anunciet illis hominibus, llamándolos ut p(o)enitentiam agant. Y quizá ia nunc / la comienzan con voluntad santa, mientras no aia fundamento / de terquedad y soberbia en contra.

A la ignorancia añade por motibo la charidad la flaque- / za, la que en muchísimos (sea por lo que se fuere) es endebilísima y / asombrosa, $\operatorname{pr}(a)$ esertim en ciertas ocasiones y determinadas cos- / tumbres, porque los pecados que nacen de ingorancia y flaqueza, / y no son de malicia, es fácil que la voluntad los aborresca, y //63r son fáciles ad veniam. El que peca por flaqueza se dice que peca / contra el Padre; el que peca por ignorancia se dice que peca contra / el Hijo, y el que peca de malicia se dice que peca contra el Spíritu / Santo. El que, por flaqueza o ignorancia pecare, se le remitirá, / si pide perdón ô en este siglo ô en el futuro. Qui pe(c)averit contra / Filium hominis, remit(t)etur ei; si autem pec(c)averit contra Spiritum / Sanctum, non remi(t)tetur ei, neque in hoc s(a)eculo, neque in futuro ${ }^{323}$; / porque peca de malicia, que es pecar amore mali, por gusto del mal / mismo y embidia del mal ageno. Es seguir la mentira impu- / gnando la verdad, aun conocida y aun reclamante con- / ciencia. Es perseguir lo bueno, y los dones del Spíritu Santo en los / buenos obfirmados en lo malo, aun viendo el mal â vista de / ojos, desmintiendo a los ojos mismos. Es el pecado de los Phari- / seos contra Spíriti, algo que persiguieron embidiosos de sus triunphos; / y aun sin poder argüir su inocencia de culpa, ni negar / los prodigios que inundaron al mundo, aun buscaron pretex- / tos para calumniarlo todo. Estos malos ia se ve que son indignos / de la gracia del sacramento pecando de malicia, y gustando de / ser malos, y repugnando la gracia misma, y los medios miseri- / cordiosos que les da el Spíritu Santo. Pero de esto se ve, y verá Vuestra Paternidad / mui poco o raro en esos miserables, cujas fealdades le afligen; porque / esos que pecan ia de malicia, de los que dice el Psalmo que la maldad prodijt quasi ex adipe iniquitas eorum, y que ia transierunt in afectum cordis ${ }^{324}$, no buscan remedio para su pecado, que no aborrecen, / sino aman gustosos, ni bienen a los sacramentos que estiman en poco, / y, si vienen, por su soberbia se conoce ver indignos. //63v

\footnotetext{
${ }^{322}$ Hch 17,30 .

${ }^{323}$ Mt 12,32.

${ }^{324} \mathrm{Sal} 72,7$.
} 
Pero, si viniesen humillados, ni la charidad dexa de recibir- / los, porque save que no ai pecado alguno irremisible absolute, sino es / la terca obstinación e impenitencia final. Save que, si el Salbador dixo, / y como excluiendo el pecado de malicia en su misericordia, que no ten- / dría perdón nunca, se entiende de la summa dificultad en per- / donarse, y por suceder esto comúmmente porque sucede que esos malos / no se arrepienten, ni se humillan, escascándoles Dios para / esa conversión aquella gracia singular de que se han hecho indignos / por maliciosos. Pero, como dice el sabio, sapientia vincit malitiam $^{325}$, nadie puede atarle â Dios las manos para que no haga esas ma- / rabillas y mutaciones dextera excelli ${ }^{326}$, no siendo nunca la ma- / licia superior, ni puede vencer a la infinita charidad de un / Dios omnipotente, aquien nada le sirbe de estorbo a sus desi- / gnios. Por esto, si viniesen abuscar su remedio esos malos, co- / mo muestren humildad, no terquedad, soberbia y obstinaci- / ón, la charidad los recibe y absuelbe, por si forte, la sapientia, / qu(a)e vincit malitiam $^{327}$, ha querido mostrar en esos sus hazañas / en tales victorias. Vea ahora Vuestra Paternidad si aun en estos pecadores / de malicia que pecan, ia no contra el Padre por flaqueza, ni con- / tra el Hijo por ignorancia, sino contra la misma gracia y mi- / sericordia, contra la charidad y santidad de Dios, ô contra el / Spíritu Santo, aún los recibimos como humillados, y quieran ia ser / buenos, ¿quánto más preste recibiremos a los pecadores flacos e igno- / rantes, que se humillan, piden y desean? Los recibe, pues, la chari- / dad, esperando que la absolución les haría algún bien, y quizá la / remisión de pecados, sino entonces ni aun en este siglo, quizá $/ /^{64 r}$ por los juicios divinos en el siglo futuro, sabiendo que en la otra / vida ai remisión de pecados como el Salbador mismo nos dixo.

Veo, dice Vuestra Paternidad, tantos males en algunos, y nada veo bueno, / que no acierto â creer ningún fruto con absolberlos. Aque digo â / Vuestra Paternidad que no está todo el campo tan encizañado que no aia queda- / do alguno grano bueno, que nos esperanze de algún fruto. No sea Vuestra Paternidad tan crédulo. Vea mi Padre la semilla que tienen de la feê, / de que ai eternidad mala ô feliz, de que ai juicio terrible, que decidan / ambas suertes, y como nadie quiere condenarse, y como to- / dos quieren ser fieles y eternizarse los que tienen esa feê, por ma- / los que sean, temen la muerte y huien de morir mal. Tienen / también creído lo que se les ha enseñado, conviene asaver: que / es preciso confesar enteramente y que, en el sacramento, ai virtud de / perdonar pecados; tienen esperanza, y en muchos es tanta, / que llega

\footnotetext{
${ }^{325} \mathrm{Sb} 7,30$. Variante: "Sapientiam autem non vincit malitia".

${ }^{326}$ Sal 76,11. Variante: "Haec mutation dexterae excelsi".

${ }^{327} \mathrm{Sb} 7,30$. Variante: "Sapientiam autem non vincit malitia"
} 
â seguridad, como que, en dando el sacerdote la absolución, / no ai más que hacer, creiendo que ban descargados de todo quanto / dixeron y confesaron, y por eso es la fatiga de decir mucho, y / que no se les quede algo para estar ia seguros, y sin miedo, para quando / estén en el Juicio Divino. Aora digo io â Vuestra Paternidad, ¿no es esta seña / (no dudosa, sino clara) de que quieren el sacramento, con voluntad / seria y santa? Pues en verdad, Padre mío, que de veinte de esos / perdidos ni aun uno abrá de el que se dude ô se pueda sospe- / char que, viniendo con esa feê de buscar la salvación, no traiga / buena voluntad, la que Vuestra Paternidad desea saber. Norabuena que la feê / no sea tal qual quisiéramos, y que, por ignorancia, se conten- / tan con lo que hacen, que aun es poco y no aflige; pero ia vienen $/ /{ }^{64 v}$ con recta intención, y, si ierran, es ignorancia, no malicia. / Por fin, no vienen pecando, ni haciendo sacrilegio, y aunque / traen pecados mui malos, no es malo el buscarles remedio. Lo / buscan rústicamente y asu modo rústico, según lo que alcanzan y cono- / cen poco las cosas de la vida eterna; y en todo caso, viniendo al / sacerdote, como â Jesucristo que los llama: Venite ad me omnes, / qui onerati estis ${ }^{328}$, y os alibiaré de la carga pesada, ¿algún fruto / para su alibio han de sacar por esa feê? Por esa esperanza / en la divina palabra, por su intención recta, según el peso / del santuario, que está en mano del que instituió el sacramento / para bien de los que creiesen, y con esperanza se llegase. Este es un / poderoso motibo, para que la charidad no se atreba anegar ese / fruto, dando la absolución charitative para bien del próximo, / que quiere vere y desea cupide el sacramento.

Norabuena que vengan fríos, y como un hielo, como / Vuestra Paternidad pondera con amargura. Pero esto puede nacer de sus / genios y natural mechanismo nada blando ni afeminado. / Sugetos ai que, rebentando de dolor y pesadumbre por algún / accidente, verbigracia por la pérdida de algún pleito ô muerte de el / querido Padre, no mostrarán blandura ni una lágrima. Ô pue- / de nacer de la turbación en aquel acto arduo delante de muchos / que están observando los movimientos, y no tanto el tiempo y el / quánto: en un acto vergonzoso así por aver de manifestar sus / pecados más feos, como por abordar con los sacerdotes, tratarlos / y ser reprehendidos de ellos, quando afuera se turbam de hablar con / gente ecclesiástica, â quien ni aun aciertan â dar los buenos días //65r $\sin$ tartamudear la lengua. Con esta turbación, ¿cómo han / de tener deboción y que se conosca en casa? Por más deboto / que Vuestra Paternidad vaia a decir misa, si lo turbó con algún incidente de esto ô / de lo otro, o por respecto â algún personaje, / que entró a oírle la / misa de repente, y conoce que le hace disgusto, si se detiene el / sacerdote en el sacrificio, se turbó mi Padre y se fue la deboción / y quedó su ánimo frío como un ielo.

${ }^{328}$ Mt 11,28. 
¿Qué sabemos si ese frío / y elado, quando Dios lo llamó con su auxilio (sino que Vuestra Paternidad duda también / que Dios llama y combida a los malos â que confiesen y se / salben) allá en su ánimo y en su casa y a sus solas ponderan- / do su mala vida, concibió buena voluntad de emmendarla, / y quizá fervorosa? Pero luego, turbado en un acto de residen- / cia y con tales circunstancias, no piense en otra cosa, sino / en salir del estrecho, y ni atienda, ni entienda nada de lo que / el confesor sentado y quieto le acumula de cosas, ¿las que por / eso no le mueven nada? Y si ala turbación se le llega ira y / amargura, porque el confesor, no lo trató con tiento ni pruden- / cia, o porque el miserable, sudando de verse en tan mal paso, / el confesor lo aburre deteniéndolo y machacándolo, ¿cómo no / se quedara frío como un hielo, y aun indispuesto y airado por / que no se atreve ni a comulgar ni a confesar otra vez? No es, pues, seña de no venir bien, ni con recta intención y voluntad, el / aparecer fríos a los ojos. En un sermón ferboroso verá Vuestra Paternidad / a los hombres sin moverse a lágrimas ni a voces, quando la blan- / dura de las mujeres llenan el aire de gritos, aires y gemidos. Y, / no obstante, vemos en los hombres conversiones más firmes //65v que en las mugeres. Otros de otro humor alegre y festibo, aun / se ríen confesando, y confiesan alegres con desenfado y no / compungidos, y, si hemos de creer al sentido y governarnos / en ese arcano por los ojos, parece que esos risones vienen a / burlarse, y deben ser excluidos por mofadores de los sacra- / mentos, ni bienen humildes sin respeto ni a los sacerdotes / jueces. Y, no obstante, examinando io esa risa, que parece / burla, hallé ser genial condición, y que, en el fondo de su ánimo, traían buena disposición y voluntad.

Aún busca más motibos la charidad, y aprecia en mu- / chos y por seña de la voluntad la obediencia con que se sugetan a una / cosa secundum se mui ardua, quales descubrir sugetos vergon- / zosos aun hombre de autoridad, y respeto cosas feísimas o- / cultas que tienen en su ánimo lo que para muchos es un rigoroso / martirio. Acuérdese Vuestra Paternidad lo que dixe ia de que, aunque la confesión ín- / tegra es de derecho divino, se dispensó para muchos pecados en la / Yglesia antigua, porque los fieles se reconocía(n) ser flacos para tanta / carga, temiendo no hujeran (d)el cristianismo ô desovedecieran el precepto. Y aora vemos que no repugnan, que se vencen, que obede- / cen, que sufren la vergüenza, no una vez en la muerte, sino / anualmente; y aun por deseo de salbarse, muchas veces al año / confiesan, se humillan y se acusan de lo que no quisieran que nadie supiese nada. En este vencimiento por obedecer la ley halla / la charidad algunos rasgos de las tres cosas que se desean: halla que / confiesan humiliter, pure et fideliter y, aunque no puede evi- / denciar el interior para ver si esa humildad, pureza y fidelidad //66r son las que convenían para la plena remisión de las culpas, justific- / cándose por la gracia. Pero se 
asegura de que lo absuelbe bien, ho- / neste et charitative. Porque le haze provecho al próximo, dán- / dole lo que le puede servir de mucho fruto, y el no darlo de nin- / guno, y aun quizá de daño. Ve claramente la voluntad seria y / santa quando ve el ahínco con que muchos desean decirlo todo con / un cuidado ia excesivo y escrupuloso, encontarlo todo aun lo / más ligero. ¿Deadónde nace, pregunto, â Vuestra Paternidad el ansia de que no / les quede cosa que no digan? Fixamente de gana y voluntad ardien- / te de obedecer el mandato de la integridad de la confesión, / excediéndose más de lo que les obliga y se les manda. Vea / aquí Vuestra Paternidad cómo se ve que confiesan pure, y ciertamente humil- / dad es decir tanto el hombre contra sí mismo quando la soberbia se / tapa mucho. En esto se conoce que confiesan humiliter en / que palam se descubren. Y ¿porqué este empeño sino tubieran / esperanza de ser absueltos y perdonados? Vea aquí, mi Padre, / el confesar fideliter con la idea de que nunca confiesan me- / jor que quando nada se les ha quedado por decir. $\mathrm{Y}$ aunque nasca / esto de rusticidad, por fin es creer y esperar.

Estas dos cosas, Padre mío, son más seguras señas de / lo bueno del caso, que para lo malo ver que viene fríos, como / un hielo. Quizá esa frialdad que aparece es que ellos no se ven / tan malos asimismos como nosotros los juzgamos. Es ver- / dad que traen abominaciones, adulterios, hurtos y juramentos, / blasfemias, poluciones y a veces bestialidades, que nosotros las / juzgamos horribles. Pero ¿qué importa si ellos, por ignorancia //66v (ô sea por otra cosa), las tienen por cosillas; que hechos a ellas toda / su vida las reputan nada ô de poca monta? Con esta idea de su vida, aunque ven que es mala y combiene la enmienda, pero / el dolor es frío consiguientemente, ô no es con aquel ferboroso ex- / tremo que quisiéramos en tan grandes delitos. Pero estos mis- / mos que, con mucho sosiego, han vomitado pecados gravísimos los / verá Vuestra Paternidad turbados, confusos para explicar y ardientes para el arre- / pentimiento, y eficaces para las propuestas de emmendar lo que / en su moral y conciencia es una maldad asombrosa, aunque / en la verdad sea cosa menor que las otras confesadas, ô quizá / ligera, y aveces ninguna. Verbigracia, el haber votado a la virgen Ma- /ría, el haverles pasado por el pensamiento (aun desechado con ho- / rror sucio) algún agrabio al sacramento ô imagen de Jesucristo, ô / pensamiento (mui resistidos) en ver imágenes de la Virgen, y / aveces en cosas bien ridículas, que auso ignoramos en qué o por / qué escrupulizen. No enseña, pues, para juzgar mal de la / confesión lo que aparece ael sentido y ven los ojos. Es menes- / ter mucha prudencia, y que alumbre la luz divina (la que / no en valde se imboca comúnmente con la bendición dispu- / esta Spiritus Santi gra(t)ia, illuminet sensus et corda nostra ${ }^{329}$ ) para / saber discernir

\footnotetext{
${ }^{329}$ Se trata de una petición del oficio medieval en honor al Espíritu Santo, presente en el Coeleste
} 
estas cosas, y no errar en lo que convenga corre- / gir, enseñar y reprehender. Esto es lo que he dicho siempre a Vuestra Paternidad: / que no puedo decirle para la práctica qué es en cada persona distinta. Personas ai tan cobardes que, si se les reprehende ô se las riñe / algo, ô se muestra algún desabrimiento con aire de castigo, / se les anudó la garganta para ia confesar ni hablar palabra //67r ninguna, y se acabó la deboción y buena voluntad. Ya nega- / rán todo lo que traen pensado. Ô quizá, por el otro extremo, a todos / lo que se les pregunta si lo han cometido, todo dicen que sí con la tur- / bación. Ôtras, si se turban, todo dicen, que se les olbida del examen / hecho de su conciencia; otras ai que, si no les reprehenden mu- / cho y se les afea sus pecados, se quedan fríos y no se atreben â / comulgar sin confesar otra vez, y preguntándoles: ¿Porqué con- / confesaron mal? Porque (responden) no me reprehendió el con- / fesor, ô porque no le impuso mucha penitencia. Otras ai que, / si se les pone mucha y no la pueden cumplir, también buel- / ben diciendo que confesaron mal. Vea aquí mi Padre Maestro un / rasgo de inifinidad de chasos, de genios, de incidentes, de sugetos, / grandes y chicos, pecadores y justos, en que es menester diverso / porte en todo para una prudente práctica, lo que Vuestra Paternidad quería que io / se la ciñese â reglas. Pero en las que he estampado, verá mi Padre / ser lo que pide, no solo difícil, sino asumpto imposible practicarse.

Esto se ha dicho generalmente aun en los que parecen fríos / e indispuestos; pero ai otras señas particulares que se conocen en / un nosequé de que no se puede dar clara razón. Y solamente se pe- / netran en cada uno en el conjunto de circunstancias, las que / quizá no valen nada para la especulativa abstraiendo de las cosas / conque se concretan. Por eso, ni io las puedo estampar en este / papel. Se ve en muchos una candidez de genio y simplicidad de / juicio y verdad de su ánimo sincero que no se duda de su volun- / tad verdadera. Se ve un modo de confesar con cierto tinte, y / tinto, que da el sentido en sus razones un aire de verdad, de de- $/ /{ }^{67 \mathrm{v}} \mathrm{seo}$, de arrepentimiento y de esperanza en la emmienda. Se ve una / cierta protección divina, que guarda â muchos en medio de sus / pecados, de otros, y de otros, deteniéndolos y templándolos con horror / y pabor que les infunde para que no se atrevan y se atemoricen. Se ve / en lo mismo que confiesan, y en las expresiones conque se culpan, / con que proponen la emmienda y aun se afligen, se humillan, / piden rigorosa penitencia y assí otras mil cosas que solo sabe la / experiencia con la prudente práctica. Se ve, digo, la verdad de / su ánimo y que su confesión muestra humildad, verdad y fideli- / dad, que son las tres cosas que se

Palmetum de 1741. En 1746, bajo la dirección de D. Agustín Montiano, la Real Academia de la Historia desplazó sus reuniones a los viernes no festivos y acordó comenzar y finalizar sus reuniones con esta invocación, propuesta por Tomás Antonio Sánchez (cf. https://www.lainformacion.com/arte-cultura-yespectaculos/la-historia-de-la-polemica-real-academia-de-la-historia_Pdt6SjBj271wuIuCJOTWT6/). 
desean en todos para ser absueltos. Pero no pueden ver señas claras en todos. Y basta lo ia dicho, / que no se vea claramente ô no aia fundamento de peso por donde se / conosca que tiene el penitente soberbio, que es embustero, que / no cree, ni espera, ni quiere el remedio y perdón de sus peca- / dos. Y, en una palabra, que viene burlándose de los sacramentos / y por motivos espurios y pecaminosos, que llamo io no solo venir / con pecados, sino venir pecando. Entonces es menester ne- / gar chatitative el sacramento al sacrílego, sino es que la chari- / dad halle modo de reducirlo y humillarlo, como sucede no / pocas veces quando aquellos males no tienen venenosas / raíces de incredulidad y obstinación.

En los demás, se ve claro el camino para dar el sa- / cramento sin escrúpulo. Porque, creiendo el reo y queri- / éndolo, deseando y pidiendo aquel bien con sincera vo- / luntad, indagada según todo el conjunto de los alegatos y / pruebas de afuera en sus dichos y adentro en sus hechos, se //68r le da la absolución de justicia, porque es suio el patrimonio / que pide y cree que le tiene guardado por gracia de Jesucristo / en el sacramento. Alomenos, si su justicia no está tan clara / que execute por ella, la charidad está cierta de que obra bien si / da la absolución por amor, si la da creiendo mucho de el / sacramento, prometida su virtud a los hombres de buena / voluntad. Esperando assí mismo de la bondad de Dios, que ha / movido al sugeto â que se humille y confiese, y quiera ia / mudar de vida y costumbres, como lo dice, lo desea, se le acon- / seja, y en lo que la ocasión permite el confesor lo solicita, espera, / digo, el que continuará la obra hasta la consumación y per- / severancia final. Con esta feê y esperanza en Dios, absuelba / â aquel en charidad, porque charidad es hacer bien al próxi- / mo, en lo que se ve que conduce para salvarlo. Por esto, solamente / será charidad negar el sacramento quando o le hará daño al reo, / como sucede al que lo recibe pecando ô sacrílegamente, o porque se / juzga que le serbirá al penitente de algún provecho dilatarlo / para humillarlo, probarlo, castigarlo, refrenarlo y reprimir su / orgullo.

Pero, como la esperiencia ha enseñado el que poco ô nada y / pocas veces sucede fruto ni provecho de ese remedio y castigo, / antes se expreimentan copiosos daños, y a veces tocan a la / salbación del próximo mismo, al que íbamos â salbar con ne- / garle la absolución, se ve que solamente se debe negar el sacramento / al que llegare sacrílego, porque a este fixamente le hará daño, y / la charidad estorba el mal del próximo, ia que no pueda darle //68v otro remedio. Pero, quitado este motibo, negar la absolución / o dilatarla, y mucho menos sin gusto del penitente que pida / y condescienda, es cosa que pide mucho tiento, y es caso que / debe dar grande miedo y escrúpulo al ministro por lo común, / sino que se vea utilidad atendiendo a la capacidad del sugeto, / que conosca el castigo para que le sirba de freno, y por eso de prove- / cho para 
algún fruto. Pero, por lo general, más daño se ve que / provecho, verbigracia, ¿qué ganancia es para muchos (y bastamente ordi- / nario) que no saben qué quiere el confesor decirles quando les avisa, / que no les absuelbe? El sacerdote se cansó en explicarles que no ban / absueltos hasta que se emmienden de sus pecados. Pero el hombre / miserable no percibe qué significa la voz absueltos, ni qué es negar la / absolución, ni qué quiso el confesor decirle con tanto como le habló / y riñó. Él solamente sabe que confesó, y ia hizo lo que había que hacer, / y lo que juzga que es su obligación. Con esta seguridad va gozoso a tomar la communión aviendo salido del mal paso, y buel- / be a su casa anunciando su buen despacho de haber recibi- / do los sacramentos. Pregúntale el confesor quándo va a confersar / otra vez, que quándo fue la última confesión, y seguro, sin / miedo, dice que el año pasado, desuerte que los delitos del año an- / tecedente jamás los confiesa, ni jamás algún sacerdote / los confesará, ni absolverá, y sin tomar la absolución, lle- / gará â morir. Qué bello fruto del escrupuloso remedio.

El motibo más ordinario de negar la absolución sue- / le ser por probar en ocho y quince días la emmienda. / Pero para esto se ve que fuera más útil darles el sacramento que $/ /{ }^{69 \mathrm{r}}$ auidarlos con tal presidio. Y ¿qué sucede? Mill males que / experimentamos cada día. El penitente se ba y no buel- / be. Y, viendo que no ba absuelto, y que ha de bolber â confesar, se anima â continuar las culpas, reduciéndose (en su juicio) / el trabajo â confesar treinta, si confesó antes veinte. Y esto / no les es mucha dificultad, buscando otro confesor; y al- / contrario, lo que vemos es que buelben, y emmendados, si absuel- / tos, se les dice que buelban, porque con la idea de que han con- / fesado con la palabra que dieron, con el freno y horror que el / sacerdote prudente les puso dificultándoles la absolución / (aunque por prudencia se les dé) y con mil precapciones que le / pone para que no les sirba de daño el sacramento con los auxilios / que en virtud del Dios les da, y con el contento conque ban agra- / decidos a la gracia que se les ha hecho y venignidad conque se les / ha tratado, se empeñan más y se esfuerzan a cumplir la pala- / bra, y aun buelben y continúan sin decirles nada con em- / mienda. Otros se enojan y se desesperan. Otros se acobardan / y se acortan, y, medrosos de no ser absueltos, jamás se atre- / ben (a) aconfesarlos. Fequentemente experimentamos en hombres / viejos ser necesario que confiesen toda su vida, porque, quando mucha- / chos ô mozos, no los absolbieron, ô con amargura los desecha- / ron. ¡Qué bello fruto del zelo, del bien, negando la absolución / sin mirar a la charidad, que es lo único a que se ha de atender! / Y, s(i) al no absuelto le sobreviniera la muerte sin ocasión de / confesarse, ô si se confiesa, quizá calla aquello de que no fue / absuelto por el miedo mismo, y muere por eso sin el presidio $/ /{ }^{69 \mathrm{v}}$ del sacramento, será un fruto nada apetecible de nin- 
guno que desea / salbarse, y que ni Dios ni la Iglesia ni el alma (quizá por eso perdi- / da) agradecerán al sacerdote celoso del sacramento que lo hu- / viese negado con tantos perjuicios. Y si, por fortuna, no sucede / nada, qualquiera charitatibo tiene pabor santo de negar el sacra- / mento quando no se ve indignidad conocida claramente en el / sugeto sacrílego por si forte le sucede algún daño al / próximo, no sea la culpa ni del ministro ni de la Yglesia, / ni por falta de auidarle con los sacramentos.

En esto no ai mal ninguno, y lo puede haber gran- / dísimo en negarlo, privando al penitente, además, de al- / gún fruto que ignoramos. Por eso dixe que para dilatar al ab- / solución en tanta infinita diversidad de genios, sugetos, / condiciones y costumbres, es menester mucho tiento, / precapción y segura utilidad, junto conque sea con ma- /ñoso alago, y que el sugeto quede gustoso, temiendo siempre / ningún fruto quando él no entra contento, o se le despide con / fastidio y desabrimiento, en lo que debe quedar el confesor / más escrupuloso que de haber dado el sacramento charitativo. / Porque darlo por charidad se le hace al próximo bien, y / no se teme ningún mal. Pues el mal único que ai que sospe- / char se podía a veces temer (y no siempre) es ne forte que el / penitente ignorante, viendo facilidad en el perdón y / que con él poco trabajo de confesar sus graves delitos, sale / siempre perdonado, se animara más a cometer, se re- / laxara más con la misericordia, apreciara poco el sacramento $/ /{ }^{70 \mathrm{r}}$ tan franco, no pesara mucho la gravedad de los pecados, viendo / que se les da fácil y presto y sin trabajo el remedio. Esto es verdad, / y es el mal único que puede suceder y deben temer los confeso- / res no charitatibos, sino que con fastidio obran el ministerio y / tienen fama en el pueblo relaxado de anchos, de pronptos, / de ligeros, y que, con perniciosa desidia, se despacha â muchas / personas con sola la misa, y como con gala de que se haze / aprisa, y sin reparar en nada, ni temer cosa alguna. / Esta es la anchura tirana, no blandura charitatiba, por / que no es práctica in (a)edificationem, sino in destruitionem. De / esta se debe tener grande escrúpulo; pero de dar el sacramento / por charidad para no hacer daño al próximo, sino provecho, / no ai porqué tener en el ánimo remordimiento alguno. / Porque la charidad y prudencia conque se administra pre- / cabe esos males que de la misericordia se temen. Pues, si se / da la absolución al miserable, es y se da con tales precap- / ciones que se le pone freno, se le abren los ojos para que vea sus / delitos, se le da estimación al sacramento, miedo a los pe- / cados, temor de otra vez no ser absuelto, y de modo / que no le sirba de daño y ciertamente de provecho.

No puedo decir â Vuestra Paternidad / más en una materia difusísima que es imposible re- / ducir â reglas. Solamente puedo decirle a mi Padre que, como / no se turbe, ni le dé ira ni fastidio el ministerio, lo hará bien y sin 
escrúpulo: Ira viri justitiam Dei non operatur ${ }^{330}$. Los pe- / nitentes sirben de tropiezo con sus rusticidades y simple- $/ /^{70 \mathrm{v}}$ zas para la ira, y de ai se turbó la prudencia, saltó la ven- / gancilla, fastidian aquellas miserias y no se halla camino para / remediarlas, y solamente se encuentra el embiarlos / con desagrado y con perjuicio. Procure mi Padre / Maestro poder siempre decir con el Psalmis- / ta: Posuerunt pe (c)catores laqueum, mihi ${ }^{331}$. Y no errará en nada, / dándole la paz y el sosiego, pru- / dencia y acierto para obrar en / provecho de los misera- /bles, y dar el sacramento / honeste, bene, chari- / tative, y basta. Va- / le, mi Padre = Sacro- / monte y maio / 15 de 1756. / Don Vicente Pastor. / Fin. / Se trasladó esta carta Año de 1761.

\footnotetext{
${ }^{330}$ St 1,20.

${ }^{331}$ Sal 118,110.
} 
